Gianmarco Daniele

Andrea F.M. Martinangeli

Francesco Passarelli

Willem Sas

Lisa Windsteiger

\title{
Wind of Change? \\ Experimental Survey Evidence on the COVID-19 Shock and Socio- Political Attitudes in Europe
}

\section{Max Planck Institute for Tax Law and Public Finance \\ Working Paper 2020 - 10}

August 2020

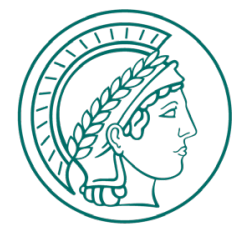

Max Planck Institute for

Tax Law and Public Finance

Department of Business and Tax Law

Department of Public Economics

http:/ / www.tax.mpg.de 
Working papers of the Max Planck Institute for Tax Law and Public Finance Research Paper Series serve to disseminate the research results of work in progress prior to publication to encourage the exchange of ideas and academic debate. Inclusion of a paper in the Research Paper Series does not constitute publication and should not limit publication in any other venue. The preprints published by the Max Planck Institute for Tax Law and Public Finance represent the views of the respective author(s) and not of the Institute as a whole. Copyright remains with the author(s).

Max Planck Institute for Tax Law and Public Finance

Marstallplatz 1

D-80539 Munich

Tel: $\quad+498924246-0$

Fax: $\quad+498924246-501$

E-mail: ssrn@tax.mpg.de

http://www.tax.mpg.de 


\title{
Wind of Change? \\ Experimental Survey Evidence on the COVID-19 Shock and Socio-Political Attitudes in Europe
}

\author{
Gianmarco Daniele* Andrea F.M. Martinangeli ${ }^{\dagger} \quad$ Francesco Passarelli ${ }^{\ddagger}$ \\ Willem Sas $^{\S} \quad$ Lisa Windsteiger ${ }^{\ddagger}$
}

\begin{abstract}
This paper investigates whether the COVID-19 crisis has affected the way we vote and think about politics, as well as our broader attitudes and underlying value systems. We fielded large online survey experiments in Italy, Spain, Germany and the Netherlands, well into the first wave of the epidemic (May-June), and included outcome questions on trust, voting intentions, policies \& taxation, and identity \& values. With a randomised survey flow we vary whether respondents are given COVID-19 priming questions first, before answering the outcome questions. With this treatment design we can also disentangle the health and economic effects of the crisis, as well as a potential "rally around the flag" component. We find that the crisis has brought about severe drops in interpersonal and institutional trust, as well as lower support for the EU and social welfare spending financed by taxes. This is largely due to economic anxiety rather than health concerns. A rallying effect around (scientific) expertise combined with populist policies losing ground forms the other side of this coin, and hints at a rising demand for competent leadership.
\end{abstract}

JEL classification Codes: D72, H51, H53, H55, O52, P52

Keywords: COVID-19, Social Trust, Institutional Trust, Survey Experiment, European Union, Welfare, Health, Taxation, Accountability, Populism, Values

Acknowledgments: We are extremely grateful to Simona Cicognani, Gloria Di Caprera, Gemma Dipoppa, Marco Le Moglie, Till Stowasser, Amedeo Piolatto and Laura Villalobos for excellent feedback and comments. Excellent research assistance was provided by Magnus Haselier.

We gratefully acknowledge generous financial support from the Max Planck Society.

Conflicting Interests: None

Ethics Clearance: Ethics Council of the Max Planck Society, Decision nr. 2020-13

Pre-Registration: AEARCTR-0005952

This draft: August 10, 2020.

${ }^{*}$ University of Milan and Bocconi University.

${ }^{\dagger}$ Max Planck Institute for Tax Law and Public Finance.

${ }^{\ddagger}$ University of Turin and Bocconi University

${ }^{\S}$ University of Stirling and KU Leuven 


\section{Introduction}

The COVID-19 crisis is a perfect storm, unprecedented in peacetime. It inextricably blends elements of what was first a health emergency, and quickly evolved into a fullblown economic and social crisis. Hundreds of thousands have seen their health directly put in jeopardy, with many more indirectly worried about future waves of infection. Government measures to control the exponential spread of the virus have ripped through our economies, and brought about what is already called the 'great interruption'. ${ }^{1}$ The resulting job losses and economic insecurity will likely be of the same scale as the economic and social-distancing measures themselves, and will change consumption patterns and working life for good. The crisis is also global, has to different degrees spared no one, and has as such widened existing gaps of inequality or social injustice as well.

Because of each of these reasons, and especially as they are at play simultaneously, the crisis can be expected to profoundly change the way individuals interact, but also relate to their institutional background. Both are vital steppingstones to understanding how any society, and its politics, function.

In this paper we investigate whether a crisis on the scale of the COVID-19 crisis can indeed bring about a critical juncture, affecting not just the way we vote and think about politics, but also our attitudes and underlying value systems. To this end we have fielded several online survey experiments in Italy, Spain, Germany and the Netherlands, well into the first wave of the epidemic (May-June). Casting a sufficiently wide net to capture the most relevant trends that could be affected by the crisis, we include four blocks of outcome questions relating to (institutional) trust, voting intentions, policies \& taxation, and identity \& values. We find significant treatment effects in all four categories, indicating that the crisis has brought about severe drops in interpersonal and institutional trust, as well as lower support for the EU and social welfare spending financed by taxes. Maintained support for incumbents and experts combined with populist policies losing ground turns out to be the other side of this coin, and hints at a rising demand for competence.

The choice of our four outcome categories - trust, voting intentions, policies \& taxation, and identity \& values - is deliberate. To gauge whether the COVID-19 crisis

\footnotetext{
${ }^{1}$ The latest GDP figures for the second quarter of 2020 , for example, stand at a dismal $-18.5 \%$ for Spain, $-20 \%$ for the UK (projected), $-12.4 \%$ for Italy, $-13.8 \%$ for France, $-10.1 \%$ for Germany, $-11.9 \%$ for the EU as a whole and $-9.5 \%$ for the US (all compared to the previous quarter).
} 
resulted in a critical juncture, a logical starting point is to look for shocks in either direction in existing trends. Our first category relates to the trend that trust in political institutions has been eroding for decades, whilst interpersonal trust has not always followed suit. Our second dimension, 'voting intentions', taps into the trend that over the last decade voters have shied away from centrist political platforms, increasingly voting for more extreme parties promising to tackle the sources of rising cultural and economic insecurity. Experts, the media and established policy institutions have often been discredited in the process, which has eroded institutional trust as well. Depending on the context, moreover, such anti-establishment platforms have successfully taken aim at austerity and globalisation, and favoured tax rises or an expansion of redistributive safety nets. Values or identities have also been recast along a more nationalist locus, with international organisations such as the EU effectively used as scapegoats. Both these trends are captured by our third and fourth outcome categories: 'policies \& taxation' and 'identity \& values'.

Our results suggest a reversal of some of these trends, and a reinforcement of others. We adopt a randomised survey flow design in which the order of the questions presented to the respondents is controlled, and designed so as to focus their attention on the epidemic (or not). Specifically, our treatment groups answer a set of COVID-19 -related questions first, thus activating crisis-awareness, after which they have to answer the full set of outcome questions. The control groups receive the two blocks of questions in reversed order instead: the outcome questions first and the COVID-19 priming questions after. This way, the control group's answers to the outcome questions cannot be influenced by the COVID-19 focus of the priming questions. We are thus able to identify the extent to which socio-political attitudes are affected by putting the crisis front and center in respondents' minds.

Moreover, to disentangle the impact of the different sides to the crisis, we have subdivided our COVID-19 priming questions along three dimensions. First, a health dimension, covering all health and social aspects of the crisis, with questions on social distancing, testing, contact with the virus, etc. Second, an economic dimension, eliciting economic concerns with questions on possible job loss, future opportunities, etc. Lastly, a 'conflict' dimension, asking whether respondents perceive the crisis as a conflict against an invisible enemy, and whether they see unity and national solidarity as the main 'winning' strategies. This then allows us to construct three conditions: a 
first condition consisting of questions related to the health dimension only (the health condition), a second related to the health and economic dimension (the economic condition), and a third related to the health and conflict dimension (conflict condition). Each of these conditions is presented to a third of the overall treatment group, which gives us three sub-treatment groups. This way, we can effectively pinpoint the effect of the economic- and conflict-related dimensions of the crisis, by comparing the response of the economic/conflict condition to that of the health condition. ${ }^{2}$

Pooling all treatments, first of all, our general results are the following. Social trust drops considerably for respondents in the treatment group, as does trust in politicians, the media and the EU. Wider EU-related attitudes on the perceived benefits and efficacy of the EU, as well as a sense of attachment to Europe, also fall. This is confirmed by our behavioural outcome measure - i.e. the willingness to read and advise on the use of a pro-EU speech for educational purposes - which is also significantly lower after answering COVID-19 questions. Trust in the police, experts and scientists goes up on the other hand, whilst trust in the government remains more or less stable.

On the policy side, we find that the support for financing the welfare state with taxes is negatively affected. This holds across all surveyed expenditure categories - poverty alleviation, health expenditure, unemployment benefits and pensions - and coincides with a higher reported dissatisfaction with the general tax burden. We furthermore find evidence that 'populist' attitudes have weakened, both in terms of support for a strong leader to deal with a crisis, and the preference to let the 'people' make the most important policy decisions instead of politicians. However, we do not find any effect on voting intentions, both for mainstream and populist parties.

Our results with respect to political institutions can be explained by two countervailing mechanisms: what we will call a 'disillusion' effect on the one hand, and a 'rally around the flag' effect on the other. The former derives from the stylized fact that crises of all kinds, from natural disasters to economic shocks, will always overwhelm governing institutions to some degree. By definition a crisis is unexpected, and citizens may have had higher expectations of their governments and institutions to grapple with the uncertainty, to be prepared for the shock, and manage it properly once it occurs.

\footnotetext{
${ }^{2}$ Explicitly activating the health dimension in all three conditions thus allows us to take the health component as fixed and to cleanly identify the additional impact of the other two dimensions being activated. This is necessary, since the health dimension by itself may already (partially) trigger economic or conflict related elements of the crisis.
} 
Disappointment and disillusion are therefore unavoidable to some extent, which then undermines trust. The COVID-19 crisis certainly ticks all of these boxes and more, as a highly infectious viral outbreak runs an exponential course and is hence even more unpredictable.

The second, 'rally around the flag' mechanism is also well-known and works in the opposite direction. Precisely because a crisis represents a situation which is out of the ordinary, citizens are more easily united around a common cause, putting their shoulders under any kind of crisis response with enthusiasm, and even patriotism if the threat concerns one's own country. Again the COVID-19 crisis fits perfectly here, as the pandemic was mostly framed as a national struggle, rather than a global one.

The 'disillusion' effect could then explain why we find decreasing trust in politicians and the EU, as these are seen to have failed to anticipate the crisis and manage it well. Similarly, the 'disillusion' might also concern fellow-citizens, if these are seen as COVID19 (super)spreaders. Both mechanisms can then translate into the decreased willingness to pay into the redistributive system, as the political class, running these programs, and the people, benefiting from them, are trusted less, as also found in Daniele and Geys (2015). On the other hand, and because national governments and especially experts were seen to actively (try to) take on the brunt of the crisis, trust in those 'in charge' received a boost, with the 'rally around the flag' effect as a strengthening factor.

Of course, to better found both mechanisms we need to dig deeper. The design of our survey experiment, set up to disentangle the impact of each of the different sides to the COVID-19 crisis, offers a first avenue here. Compared to the general analysis where all respondents were pooled, important differences emerge when focusing strictly on the health condition in our first sub-treatment. Trust in politicians levels off slightly less, trust in the government turns positive and most importantly, voting intentions swing in favour of the incumbent national government. Disagreement with individual and general tax burdens also remains neutral. Both outcomes suggest the 'disillusion' effect shines through less if only social and health aspects of the crisis are activated, and that 'rally around the flag' dynamics work in favour of the incumbent government but less so for politics as a whole, let alone EU institutions.

This picture changes drastically, however, once we include the economic dimension. This second sub-treatment shifts all trust indicators squarely into negative territory, and activates disagreement with the tax burden. It also marks a lower willingness to give 
up personal freedom in exchange of individual and public safety, and (further) erodes support for populist as well as incumbent parties. These results indicate the 'disillusion' effect is in full swing when the economic consequences of the crisis are brought to mind. Inversely, when respondents are presented with the health and 'conflict' dimensions in the third sub-treatment, support for science and experts shoots up significantly, leaving all other indicators constant. This again suggests a 'rally around the flag' effect is at play, here centred on (scientific) expertise.

Another way to underpin our proposed mechanisms is to use our treatment questions for further heterogeneity analysis. What we find is that treated respondents who willingly followed the emergency measures report higher levels of trust in institutions, and perceive their individual and the general tax burden as less problematic. This can be interpreted as a proxy of the 'rally around the flag' effect, in the form of cooperation with the government. Among those who are concerned about their health, a similar argument can be made, which shows in slightly higher levels of institutional trust but mostly in support for taxation and welfare programs.

Of course, our results should first and foremost be interpreted as a shock, diverging from existing trends. Whether we have in fact uncovered a critical juncture setting these trends on an entirely different path, can only be ascertained by conducting followup waves of our survey experiment. Depending on how governments will manage the economic recovery and/or a possible resurgence of the virus will be a crucial factor here. In any case it will be interesting to see whether the rising demand for competent leaders and policies we uncover is met in the future, or whether the 'disillusion' effect will eventually be translated into increased populist support.

The paper is organized as follows. Sections 2 and 3 present the details of the survey and the experimental design. Sections 4 and 5 present the estimation strategy and our findings. We conclude in Section 6.

\section{Related Literature}

Our work first of all contributes to the small yet growing strand of papers looking into the effect of the COVID-19 crisis on trust and political attitudes. The main innovation of our paper is to study the overall effect of the crisis by providing experimental evidence on a comprehensive set of socio-political attitudes across several countries, as well as the mechanisms behind this effect. While previous studies with a similar scope are based on 
correlational evidence or focus on COVID-19 specific aspects (e.g. lockdown effects), so far experiments have been used only to study specific outcomes in a one-country context.

More specifically, the analysis in Brück et al. (2020) is based on a new global survey and uses correlational statistics. It shows that those who have had contact with sick people and are unemployed exhibit lower trust in people and institutions (police, courts, local \& national government), whilst personally experiencing symptoms of the disease did not play a part. Using an online survey fielded in March 2020 in several Western European countries, Bol et al. (2020) compare respondents who took the survey before and after the start of the lockdown. Their results suggest lockdowns have increased voting intentions for incumbent parties, trust in government, and satisfaction with democracy. Bækgaard et al. (2020) arrive at similar conclusions based on a Danish survey. Relying on experimentally induced variation our treatment effects also suggest such a 'rallying effect' is at play, yet our economic treatment condition marks the extent to which it can be crowded out by the economic fallout of the crisis. This suggests the lockdown rally itself was temporary, and tapered out as more material and social consequences of the crisis manifested itself.

Combining the approach of Bol et al. (2020) and Brück et al. (2020), Amat et al. (2020) compare reported political attitudes in January and March for a panel of 818 respondents in Spain. Having an infected relative or friend is shown to boost the preference for technocratic government and competent management. They also find correlational evidence that the crisis has eroded political trust and democratic preferences, as well as increased support for authoritarian emergency measures and strong leadership, even at the cost of personal freedom. Whilst the trust and competence results are in line with our experimental treatment effects, we find the inverse when it comes to populist attitudes and the importance of civil liberties. This could be because the incompetence of populist rulers in other countries had been exposed by the time our study was fielded in May/june. ${ }^{3}$

Foremny et al. (2020) implement two information treatments on the COVID19 fatality rate - across age groups and incidence across regions - on a pool of 1000 respondents in Spain in early April. Results suggest that preferences for health care expenditures have almost doubled, especially in terms of ICU capacity and when respondents belong

\footnotetext{
${ }^{3}$ In terms of political fallout of the crisis, see also Merkley et al. (2020) on the effect on political and public cross-partisan consensus, and Grossman et al. (2020) as well as Kushner Gadarian et al. (2020) on the importance of partisan affiliation to maintain compliance with lockdown measures.
} 
to groups facing a higher risk. Our heterogeneity subconditions are in line with this finding, showing that those concerned about the virus or those that have contracted it, would like to spend more taxes to finance health care.

In a survey experiment conducted in the Czech Republic, Bartos et al. (2020) employ a similar experimental strategy to ours and find evidence that the pandemic has fuelled respondents' hostility towards foreigners, but not towards domestic out-groups and minorities. This aligns with our own finding that treated respondents feel health care should be reserved to 'own' citizens. Durante et al. (2020), lastly, find that in Italian areas where civic capital is higher, compliance was stronger. While they thus observe that more trustful individuals are more willing to comply with the rules, we find that these individuals are also more distrustful of others when primed with COVID-19 questions.

Second, our focus also overlaps with the literature studying the effect of pandemics on institutional trust and political preferences. Aksoy et al. (2020) find that epidemic exposure in what psychologists refer to as an individual's "impressionable years" (ages 18 to 25) has a persistent negative effect on confidence in political institutions and leaders. They find similar negative effects on confidence in public health systems, suggesting that this loss of confidence is associated with healthcare-related policies and their limitations at the time of the epidemic. Our findings chime well with these results, although we also uncover the sizeable effect of economic insecurity related to the crisis. Importantly, since the main premise of Aksoy et al. (2020) is that exposure to a pandemic during one's impressionable years leads to persistent effects on trust, this would indicate we have indeed uncovered a critical juncture. Blickle (2020) secondly, show that influenza mortality in 1918-1920 is correlated with societal changes, as measured by municipal spending and city-level extremist voting, in the subsequent decade.

The rally-around-the-flag literature, thirdly, holds that approval rates for incumbents usually increase when a crisis is due to an external conflict, while they decrease when it is due to an economic downturn. ${ }^{4}$ The COVID-19 pandemic exhibits both of these characteristics. It can be perceived as an inevitable catastrophe, as an external enemy to fight against. But it can also be perceived as economic disaster (Fetzer et al., 2020), from which the government should have protected citizens. In line with this literature, we find that support for the incumbent is maintained or even increases in the health

\footnotetext{
${ }^{4}$ See, among others, Hetherington and Nelson (2003), Gibler et al. (2012) and Ariely (2017), and the literature therein.
} 
sub-treatment, while it decreases in the economic sub-treatment.

Since the economic effects of the pandemic indeed seem to play a crucial role, fourthly, our work is close to the literature documenting dissatisfaction with the political establishment during severe economic crises. Stevenson and Wolfers (2011) document an enormous loss of trust in US political institutions in the aftermath of the Great Recession. Frieden (2016) observes increased dissatisfaction with EU institutions over the course of the 2008-2012 crisis (see also Dustmann et al. (2017), Hernández and Kriesi (2016); Guiso et al. (2020); Margalit (2019)). Algan et al. (2017) uncover a strong relationship between economic insecurity and populist voting in Europe. We do not find clear evidence that the COVID-19 crisis strengthens the preference for populist parties, the association even becomes clearly negative in the economic sub-treatment. ${ }^{5}$

The perceived mishandling of an economic crisis by the political class and a country's broader institutions then brings about a sense of disillusion, which in turn undermines trust. This mechanism can also work in different contexts, however. In that light our paper also relates to the literature studying whether natural disasters, and their fallout, help or hurt politicians' electoral fortunes. Some studies argue that voters punish incumbent politicians indiscriminately after such disasters (Achen and Bartels (2004, 2017)). Conversely, other studies find that voters are able to assign praise and blame by considering incumbent reaction to the natural disaster (Healy and Malhotra (2009); Bechtel and Hainmueller (2011); Gasper and Reeves (2011); Heersink et al. (2017)).

Lastly, our research also ties into the literature investigating the effect of crises on social trust. Work on the effect of global pandemics on social and interpersonal trust specifically, however, is rather sparse. Aassve et al. (2020) find evidence that the Spanish flu epidemic of 1918/19 had long lasting negative consequences for social trust. Using the fact that cultural traits and attitudes tend to be passed on across generations, they employ GSS (General Social Survey) data from respondents who are direct descendants of migrants to the US to construct an estimate of social trust before and after the pandemic for each country of origin. We expand on these findings by using experimental variation to show that there is a causal negative effect of the pandemic on social trust. From a wider perspective, Owens and Cook (2013) find that worsening local economic conditions due to the 'Great Recession' of 2008 had a negative effect on interpersonal

\footnotetext{
${ }^{5}$ As mentioned above, the populist economic recipe seems to have lost its specific appeal when it comes to COVID-19, possibly because the incompetence of some populist leaders became apparent during the crisis.
} 
trust and Kevins (2019) detects a negative effect of labour market vulnerability on social trust. Meanwhile, Bauer et al. (2016) show that wars can strengthen interpersonal trust and cooperation.

For a further extensive overview of the rapidly expanding body of work on the economics of COVID-19 in general, we refer to Brodeur et al. (2020), and the literature therein.

\section{The Survey}

We hired the professional survey company Respondi to handle the distribution of the link to our online survey in four European countries: Germany, Italy, the Netherlands and Spain. ${ }^{6}$ The survey was simultaneously distributed in all four countries in the first two weeks of June 2020. From each country, we collected data from a random sample of adults (below 70 years of age) exceeding 2000 individuals, achieving a total sample size of 8235 observations, as detailed in Table $1 .^{7}$ We aimed at representativeness of the samples by age, geographic area of residence and gender. We further tried to achieve a distribution of disposable equivalized household income as close as possible to the one provided by Eurostat. $^{8}$ The English survey questionnaire was translated in all languages by the native-speaking authors, except for the Spanish version which was instead translated by professional translation services offered by Respondi. Thus the survey was administered in each country's local language. ${ }^{9}$

\footnotetext{
${ }^{6}$ https://www.respondi.com/EN/

${ }^{7}$ We are a priori able to detect a minimum effect $\mathrm{MDE}=0.12$ on standardised outcome measures at $\alpha=0.05$ and power $\pi=0.8$ in within-country analyses.

${ }^{8}$ EU-SILC: https://ec.europa.eu/eurostat/web/main/home

${ }^{9}$ The English translation of the full questionnaire can be found in Appendix F. The interested reader can take the survey in the local languages by using the links below.

Dutch: https://taxmpg.eu.qualtrics.com/jfe/form/SV_850cx8lc4806tzT

German: https://taxmpg.eu.qualtrics.com/jfe/form/SV_5ouJ8nUBnj111Mp

Italian: https://taxmpg.eu.qualtrics.com/jfe/form/SV_5apXa5HwDkB55it

Spanish: https://taxmpg.eu.qualtrics.com/jfe/form/SV_0ln902bfxiBsH1r
} 


\begin{tabular}{lcc}
\hline Country & Sample size & Share of total \\
Germany & 2161 obs. & $26.24 \%$ \\
Italy & 2003 obs. & $24.32 \%$ \\
Netherlands & 2071 obs. & $25.15 \%$ \\
Spain & 2000 obs. & $24.29 \%$ \\
\hline Total & 8235 obs. & $100.00 \%$ \\
\hline \hline
\end{tabular}

Table 1: Sample size per country

The survey flow was structured as follows:

Background information Gender, age, marital status, household size (number of adults and number of children), household monthly disposable income.

Socio-political attitudes block (outcome questions) We ask respondents about a wide range of their socio-political attitudes, the outcome questions of our survey. These questions can be grouped into four different dimensions summarised below: trust, taxation, voting and EU preferences, identity and values. A complete list of the outcome questions can be found in Table 2 .

Trust These questions cover the respondents' generalised and particular trust attitudes towards society, institutions (national government and European Union) and political leaders, science, the media and the police.

Taxation The respondents are asked to state their level of support for various forms of state economic intervention. These include support for generic market intervention, for redistributive taxation, use of public health systems and whether they feel their own and the general tax burden in their country is excessive.

Voting and EU preferences We elicit both voting intentions and political attitudes. We then use voting intentions to classify the respondents according to whether they would, in hypothetical elections, support incumbent governments, populist or eurosceptic parties. Among the political attitudes we elicit their placement on the left-right spectrum, whether they perceived the EU to have been beneficial for their country, their preference for a strong leader, for devolution of political powers to the citizens and their support for civil and political liberties. 
Identity and values This dimension covers the respondents' perceived belonging and identification with various geopolitical reference areas, ranging from local to supranational (European). We moreover elicit the respondents' willingness to trade-off their own private freedom for the sake of their own safety, that of their immediate relations and of the general public. Finally, they provide their trade-off between universal and traditional values and their preference for globalization of markets.

COVID-19 block (treatment questions) The respondents receive a range of questions concerning the COVID-19 epidemic and its consequences. These were divided into three categories.

Health We ask the respondents which of the commonly recommended behaviours to contain the spread (e.g. social distancing, disinfection, testing) respondents have adopted, whether they had COVID-19 cases among their acquaintances and family members, and whether they were concerned for their health and for that of those around them. Notice that while labeling this category "Health" these questions are intended to elicit the respondents' basic day-to-day experience of the COVID-19 epidemic rather than its strictly medical aspects.

Economic We here elicit how the respondents perceive the economic consequences of the epidemic, whether they were impacted themselves in terms of job loss and future job opportunities.

Conflict Finally, we ask whether the respondents perceive the COVID-19 epidemic as a conflict against an invisible enemy and whether they perceive unity and national solidarity as the main "winning" strategies.

Further background information Highest educational attainment, primary information sources, employment status, immigration background, political beliefs and voting behaviour. 


\begin{tabular}{|c|c|c|}
\hline Category & Outcome variables & Label \\
\hline Trust & $\begin{array}{l}\text { Text agreement question (behavioural outcome) } \\
\text { Trust in politicians } \\
\text { Generalised social trust } \\
\text { Trust in the Government } \\
\text { Trust in the Police } \\
\text { Trust in the Media } \\
\text { Trust in Science } \\
\text { Trust in the European Union }\end{array}$ & $\begin{array}{l}\text { Macron Speech } \\
\text { Trust Politicians } \\
\text { Social trust } \\
\text { Trust Government } \\
\text { Trust Police } \\
\text { Trust Media } \\
\text { Trust Science } \\
\text { Trust EU }\end{array}$ \\
\hline Taxation & $\begin{array}{l}\text { Market regulation } \\
\text { Taxation for poverty relief } \\
\text { Taxation for public health provision } \\
\text { Taxation for income replacement in unemployment } \\
\text { Taxation for income replacement in old age } \\
\text { Preference over current immigration level } \\
\text { Attitudes towards public healthcare access for immigrants } \\
\text { Perceived overall fiscal burden } \\
\text { Perceived own fiscal burden }\end{array}$ & $\begin{array}{l}\text { Regulate Markets } \\
\text { + Taxes - Poverty } \\
\text { + Taxes + Health Exp. } \\
\text { + Taxes + Unemployed Welfare } \\
\text { +Taxes + Pensions } \\
\text { Too Many Immigrants } \\
\text { Health Exp. to Natives } \\
\text { General Tax Too High } \\
\text { Self Tax Too High }\end{array}$ \\
\hline $\begin{array}{l}\text { Voting \& } \\
\text { EU prefer- } \\
\text { ences }\end{array}$ & $\begin{array}{l}\text { Incumbent vote } \\
\text { Populist vote } \\
\text { Euroscept. vote } \\
\text { Placement in political spectrum } \\
\text { Perceived benefit of the EU } \\
\text { Perceived efficacy of the EU } \\
\text { Would vote to leave the EU } \\
\text { Prefers a strong leader } \\
\text { Preference for privacy protection } \\
\text { Attitudes towards placing power in the people's hands } \\
\text { Preference for media freedom } \\
\text { Is convinced plutocracies control politics }\end{array}$ & $\begin{array}{l}\text { Incumbent Voting } \\
\text { Populist Voting } \\
\text { Eurosceptic Voting } \\
\text { Ideology (Left to Right) } \\
\text { EU Benefit } \\
\text { EU Efficacy } \\
\text { Leave EU } \\
\text { Strong Leader } \\
\text { More Privacy } \\
\text { People Power } \\
\text { Free Media } \\
\text { Plutocracy }\end{array}$ \\
\hline $\begin{array}{l}\text { Identity \& } \\
\text { values }\end{array}$ & $\begin{array}{l}\text { Sense of local belonging } \\
\text { Sense of national belonging } \\
\text { Sense of European belonging } \\
\text { Would give up personal freedom to protect own safety } \\
\text { Would give up personal freedom to protect family's safety } \\
\text { Would give up personal freedom to protect public safety } \\
\text { Upholds global human rights } \\
\text { Upholds respect of local traditions } \\
\text { Would have less globalisation }\end{array}$ & $\begin{array}{l}\text { Belong Town } \\
\text { Belong Nation } \\
\text { Belong EU } \\
\text { - Own Freedom + Own Safety } \\
\text { - Own Freedom + Family Safety } \\
\text { - Own Freedom + Public Safety } \\
\text { Global Human Rights } \\
\text { Respect Traditions } \\
\text { Less Globalisation }\end{array}$ \\
\hline
\end{tabular}

Table 2: List of outcome variables by category

\subsection{Incentivised willingness to support European integration}

In order to better capture how the respondents' attitudes towards the European Union are impacted by the epidemic and its various dimensions, the socio-political attitudes block includes an incentivised behavioural measure of their willingness to engage in an action explicitly framed as supportive of the European integration project. The respondents are told that: 
"For educational purposes, we are considering informing students about the importance of the European Union using real texts. We selected a speech given in front of the European Parliament promoting European integration." 10,11

We then ask the respondents whether they would be willing to read a five-minute long transcription of the speech and to give us their opinion about the suitability of the text for the purpose it was selected for. This way we provide a clear incentive to respondents who are not willing to spend five minutes of time (it took on average approximately 20 minutes to complete the survey without reading the text) reading a pro-European Union text and to provide their opinion, to decline (see also Dellavigna et al. (2017)). We explicitly fixed the amount of time needed to read the speech in order to fix beliefs about the length of the task and the amount of time and effort needed to complete it. Further, the explicit reference to the educational usage of the text (in a Public Economics undergraduate course at the University of Stirling taught by one of the authors) serves the purpose of providing the respondents with a sense of consequentiality of the action and effort invested in it. The identity of the speaker and the context in which the speech was given (apart from it being addressed to the EU Parliament) was not disclosed to the respondents at the time of choosing whether to read the text or not. We also informed the respondents that their agreement or lack thereof will not affect their payment. In case of agreement, the respondents are told that they will read and review the text only at the very end of the survey. ${ }^{12}$

We interpret the respondents' choice of (not) reading the text and providing their opinion on its suitability for the stated purpose as (un)willingness to support the European integration and not the rating provided. It might very well be the case that a respondent with extremely positive attitudes towards the European integration might legitimately find the text unsuitable for the purpose and assign it a low rating. A non-trivial choice was whether to explicitly frame the action as supportive of European integration or whether to maintain a more neutral wording (e.g. by removing the word "importance" and replacing "promoting" with a neutral "about the" in the quoted text

\footnotetext{
${ }^{10}$ See Appendix $\mathrm{F}$ for an English transcription of the whole question.

${ }^{11}$ An English transcription of the original speech can be found at the following link: https://www.elysee.fr/emmanuel-macron/2018/04/17/speech-by-emmanuel-macron-president-of-therepublic-at-european-parliament.en

${ }^{12} \mathrm{~A}$ discussion of the experimental challenges posed by this question and of how they are here addressed can be found in Section 3.1.
} 
above). Had we chosen the neutral wording, however, the interpretation of the agreement to read the text would have not been straightforward. As argued above, framing it as pro-integration allows for a combination of agreement to read and low-rating assigned to still be interpretable as supportive of the European integration. This would not have been the case with neutral wording, as a respondent antagonising the integration process could have agreed to read the text with the mere intent of assigning a low score. It can be argued that our behavioural measure of support for the European integration could have in such case been the rating distribution. Notice however that those choosing not to read the text would have been dropped out of the analysis and that the incentivisation would have been lost (it is costly to choose to spend five more minutes to read but it is costless to assign the rating). Our choice does not completely exclude the possibility that the respondents might accept to read and then assign ratings without reading. The incidence of such behaviours is however likely to be orthogonal to our experimental design and smaller than with neutral wording. Our choice moreover allows us to perform analyses allowing us to gauge the validity of the responses collected and of our behavioural measure.

The analyses presented in Appendix E confirm the validity of our behavioural measure and our interpretation. In order to perform such analyses, we recorded the time spent by the respondents between accessing the text and moving on to the following page. This way we are able to discriminate between respondents who, after agreeing to reading the text, only provide their opinion without actually investing any effort and to relate the time spent on the question with the ratings provided (a ten-step numeric variable). We thus gain an insight into the attitudes towards the European integration process of those who agree to read, and into the systematic differences in the distribution of such responses across experimental conditions.

\section{Experimental Design}

Our design consists of two main experimental conditions: A Baseline condition in which the respondents provide their unprimed answers to our target questions, and a COVIDFIRST condition in which the respondents provide instead their answers to our target questions after having been primed with various aspects of the COVID-19 crisis. This means that participants in the Baseline condition answer the survey in the order described in Section 2, whereas for participants in the COVIDFIRST condition the order 
of the Socio-political attitudes block and the COVID-19 block is switched. ${ }^{13}$

Further, as detailed in Section 2, the COVIDFIRST condition is divided into three "sub-conditions" meant to delve deeper into the mechanisms at play. Specifically, all respondents receive questions about their perceptions of and behaviours in relation to the COVID-19 epidemic as a health crisis. The respondents are then divided into three mutually exclusive groups. A first group is not subject to any further intervention. We will henceforth refer to this group as to the Health condition. A second group which we will henceforth refer to as the Economic condition receives a set of questions emphasising the economic consequences of the COVID-19 crisis in addition to the health related questions. Finally, a third group which we will refer to as the Conflict condition receives (again in addition to the health questions) a set of questions mimicking the conflict rhetoric often used in relation to the epidemic and emphasising the explicit need for social solidarity in winning the "war against the invisible enemy". Summarising, while all respondents in COVIDFIRST receive the COVID-19 block of questions before the socio-political attitudes block, we randomise whether and which of the economic and conflict dimension of the epidemic are emphasised by the questions. The experimental design is summarised in Table 3 .

\begin{tabular}{|c|c|}
\hline Baseline & COVIDFIRST \\
\hline Background information & Background information \\
\hline Socio-political attitudes block (outcomes) & $\begin{array}{l}\text { COVID-19 block } \\
\text { Presented with one of: } \\
\text { Health } \\
\text { Health }+ \text { Economic } \\
\text { Health + Conflict }\end{array}$ \\
\hline $\begin{array}{l}\text { COVID-19 block } \\
\text { Presented with one of: } \\
\text { Health } \\
\text { Health + Economic } \\
\text { Health + Conflict }\end{array}$ & Socio-political attitudes block (outcomes) \\
\hline Further background information & Further background information \\
\hline
\end{tabular}

Table 3: Summary of the experimental design

\footnotetext{
${ }^{13}$ See Alesina et al. (2018) for another example of the use of this strategy of randomizing the order of survey blocks.
} 
Worth mentioning is that this design allows us to better disentangle the impacts of the economic and of the conflict dimensions of the epidemic from those of the pure health dimension than it would have been if all three dimensions were assigned exclusive groups of respondents. The COVID-19 crisis is primarily a health crisis which also bears consequences and implications on the economy and more generally on society. Exposing respondents to the, for instance, economic consequences of the crisis exclusively does not exclude the activation of some degree of health-related concerns over which the researcher has no control. Conversely, explicitly activating the health dimension in all conditions in the same way as in the Health condition allows us to take the health component as fixed and to cleanly identify the impact of the other dimension being activated.

Respondents assigned to the Baseline condition are exposed to the same sub-conditions (health, health and economic, health and conflict) as respondents in the COVIDFIRST condition. The sub-conditions are however expected to have no impact on the answers provided in the outcomes block in the Baseline condition, as the treatment questions come later in the survey flow. Placebo tests performed on these respondents are presented in Appendix C.2.

\subsection{Further considerations}

We identify two primary potential confounds in our experimental design.

Fatigue Fatigue might influence the propensity to choosing to review our text on European integration. To see this, remember that we randomize whether the outcome variable questions come before or after the questions about the COVID-19 crisis. Half of the respondents will receive the question on whether they wish to read a lengthy text (explicitly fixed at 5 minutes of time) about the European integration relatively early in the survey, while half will receive it relatively late. Among the latter, greater fatigue is expected to decrease the likelihood of agreement. Fatigue would therefore cause us to over-estimate a negative impact of the COVIDFIRST condition, which is why we treat it as a confound deserving high priority.

The position of the text agreement question is therefore randomly placed at the beginning or at the end of the outcomes block: its placement varies between early on, somewhat in the middle and towards the end of the entire survey, orthogonally to the experimental conditions. Moreover, in case of agreement, the respondents will read the 
text and provide their opinion at the end of the questionnaire to shield the following parts of the survey from additional fatigue originating from the text review task.

Experimenter demand effects Participants to surveys or experiments might infer the researchers' underlying objectives from the questions asked and/or from the experiment's architecture, and act to comply with what they believe are the experimenter's objectives Zizzo (2010). In our case, a respondent might form an idea that our ultimate objective is that of measuring socio-political sentiments, particularly towards the EU, from the questions we asked. Demand effects might bias our respondents' answers in uncontrollable ways, thus reducing the likelihood of observing the effects of interest.

We cannot address this concern directly, as we must tradeoff between reaching our research objectives and eliminating the risk of demand effects. We however are able to evaluate the likelihood of demand effects polluting our questionnaire by exploiting the randomization of the position of the text agreement question. The explicit proEU sentiment in that question leads to a strengthened pro-EU demand effect affecting subsequent questions beyond the natural demand induced by the questionnaire itself de Quidt et al. (2018). Comparing the responses of those exposed to strengthened demand effects at the beginning and at the end of the outcomes block allow us to establish whether the survey is susceptible to any demand effect originating from the questionnaire itself. ${ }^{14}$

\section{Statistical Models and Analyses}

At a first level, we evaluate the overall impact on the respondents' socio-political attitudes of answering the COVID-19 block first. We therefore estimate the following OLS model:

$$
Y=\beta_{0}+\beta_{1} C O V I D F I R S T+\beta_{2} X+\beta_{3} W+\beta_{4} \kappa+\varepsilon,
$$

where $Y$ is the vector of answers from the socio-political attitudes block, COVIDFIRST is equal to 1 if the respondent answered the COVID-19 questions first and zero otherwise, $X$ and $W$ are respectively vectors of individual and regional covariates, and $\kappa$ denotes country fixed effects. We cluster the standard errors at the province level (NUTS-3). ${ }^{15}$

\footnotetext{
${ }^{14}$ Appendix C.1 shows no evidence for demand effects originating from the text agreement question.

${ }^{15}$ Our results are unchanged by usage of different clustering levels.
} 
We further delve deeper into the analysis of the mechanisms behind the effect of the epidemic on our respondents' socio-political attitudes by evaluating the additional impact of the economic crisis and conflict dimensions of the epidemic beyond the health hazard dimension. Section 3 illustrates the experimental strategy we adopted to achieve this objective. As there explained, we fix the health dimension across sub-conditions and use it as a baseline to treat the respondents with their everyday experience with the COVID-19 epidemic with the aim of evaluating the further impact of the economic and conflict dimensions. Our statistical strategy is reflective of this approach. For simplicity, construct a categorical variable denoted $T$ taking values

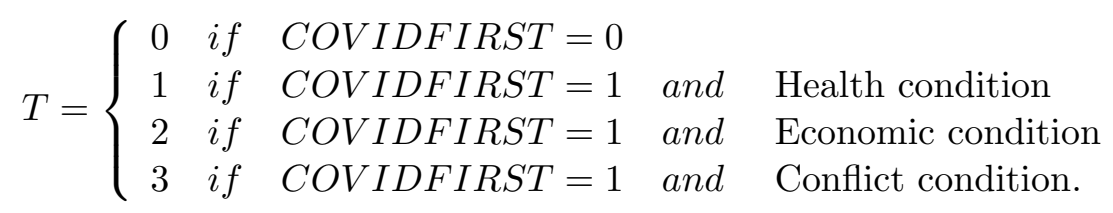

In a first step at deepening our analysis, we therefore establish the baseline effect of on socio-political attitudes of experiencing a health crisis by restricting model (1) to the Baseline and Health condition only:

$$
Y=\beta_{0}+\beta_{1} T+\beta_{2} X+\beta_{3} W+\beta_{4} \kappa+\varepsilon, \quad T=\{0,1\} .
$$

We next evaluate the additional impact of the economic and of the conflict aspects of the COVID-19 epidemic beyond the health hazard. Remember that the Economic and Conflict conditions add questions concerning to the economic and conflict dimensions of the epidemic to the health related questions already included in the Health condition. We therefore take the outcomes measured in the Health condition of the COVIDFIRST treatment as the baseline estimates for two additional models, ultimately measuring the impact of adding the economic or conflict dimensions to the health baseline. The first model concerns the economic dimension:

$$
Y=\beta_{0}+\beta_{1} T+\beta_{2} X+\beta_{3} W+\beta_{4} \kappa+\varepsilon, \quad T=\{1,2\} .
$$

Notice that as COVIDFIRST (the indicator taking value 1 if the respondent answered the COVID-19 block before the outcomes block) is fixed to 1 and $T$ is constrained to 
taking values 1 and $2, \beta_{1}$ can be interpreted as the impact of having answered the questions in the Economic condition compared to having answered the questions in the Health condition among respondents who answered the COVID-19 question block first.

An analogous model is estimated to evaluate the impact of the Conflict condition:

$$
Y=\beta_{0}+\beta_{1} T+\beta_{2} X+\beta_{3} W+\beta_{4} \kappa+\varepsilon, \quad T=\{1,3\} .
$$

To ease the interpretation of our results, all outcome variables have been standardised with respect to the outcomes in Baseline.

All regressions control for gender, age class, employment status, education, immigrant status, family status and number of family members, equivalised household income (coded into five quantiles), and a dummy indicating the position of the Macron Speech question (see Section 3.1 for more details).

\section{Results}

\subsection{Aggregate Analyses}

In this section we report the estimates of model (1) on the entire sample. In Figure 1, we compare all treated individuals (COVIDFIRST) with the Baseline group. In this first specification, we therefore do not differentiate across health, economic and conflict sub-condition groups. The analysis is organized around our four blocks of outcomes: a) trust, b) taxation, c) voting and EU preferences and d) identity and values. All outcomes have been standardised with respect to the Baseline group. All coefficients should hence be interpreted relative the unit standard deviation (SD) of the Baseline.

Figure 1 provides strong evidence about the impact of COVIDFIRST across different sets of outcomes. We report the estimated coefficients in Appendix B. First, we find very heterogeneous effects on trust. The COVID-19 treatment has a negative and statistically significant effect on social trust (-0.13 SD), trust in media (-0.08 SD), trust in politicians (-0.04 SD) and trust in the European Union (-0.12 SD). There is no effect on trust in government. Conversely, we find a positive and significant effect on trust in police $(+0.08 \mathrm{SD})$ and science $(+0.09 \mathrm{SD})$. In line with a negative effect on EU attitudes, the incentivised behavioral outcome, i.e. being willing to read a pro-EU speech for educational purposes, reports a strongly negative and statistically significant coefficient (-0.14 SD). Indeed, the bottom panels report similar findings related to the EU: the 
bottom left panel shows a significant decrease in perceived EU efficacy (-0.10 SD) and benefit (-0.10 SD); the bottom right one reports a negative effect on EU identity (-0.08 $\mathrm{SD})$. These heterogeneous effects might underlie different evaluations on the performance of such institutions in the face of the COVID-19 crisis, which then affect their level of perceived trustworthiness.

Second, the top right panel shows a consistently negative effect on attitudes towards levying taxes to finance the welfare state. This is true for poverty alleviation (-0.10 SD), health expenditure (-0.07 SD), unemployment benefits (-0.06 SD) and pensions (-0.07 SD). ${ }^{16}$ In line with these findings, respondents in COVIDFIRST report that their fiscal burden is too high (0.06 SD). These findings show that priming people about COVID19 decreases willingness to finance the welfare state, in a time in which politicians are pressured to tremendously increase welfare expenditure to deal with the health crisis and an economic downturn. As mentioned in Section 1, a 'disillusion' effect towards institutions and fellow citizens might explain why we find a decreased willingness to pay into the redistributive system.

Third, we find some evidence of a negative effect on populist attitudes (bottom left panel) in terms of preferring a strong leader (-0.05 SD) and allowing people to make the most important policy decisions (-0.05 SD). However, we do not find any effect on voting preferences. Similarly, the bottom right panel shows no conclusive evidence of an effect on self-reported values and attitudes towards freedom and public safety.

In Appendix A, Figures A1, A2, A3 and A4 display the results from country-level analyses. Overall, the effects are strikingly similar across Germany, Italy and the Netherlands. Spain seems however to stand out, as both the effects on trust and welfare preferences seem to be attenuated. First, we do not find a clear decrease in trust for institutions, as there is not a significant decrease in trust for media and politicians. In terms of EU attitudes, while COVIDFIRST decreases trust in the European Union, it does not substantially affect other EU related outcomes, like EU benefit, EU efficacy and attachment towards the EU. On the other hand, we do not find a clear decrease in preferences towards levying taxes. We further discuss the Spanish case in the next section.

\footnotetext{
${ }^{16}$ Interestingly, we find a negative effect on whether the public health care system should prioritize locals over immigrants.
} 
Figure 1: Effect of COVID-19 priming (Entire sample)
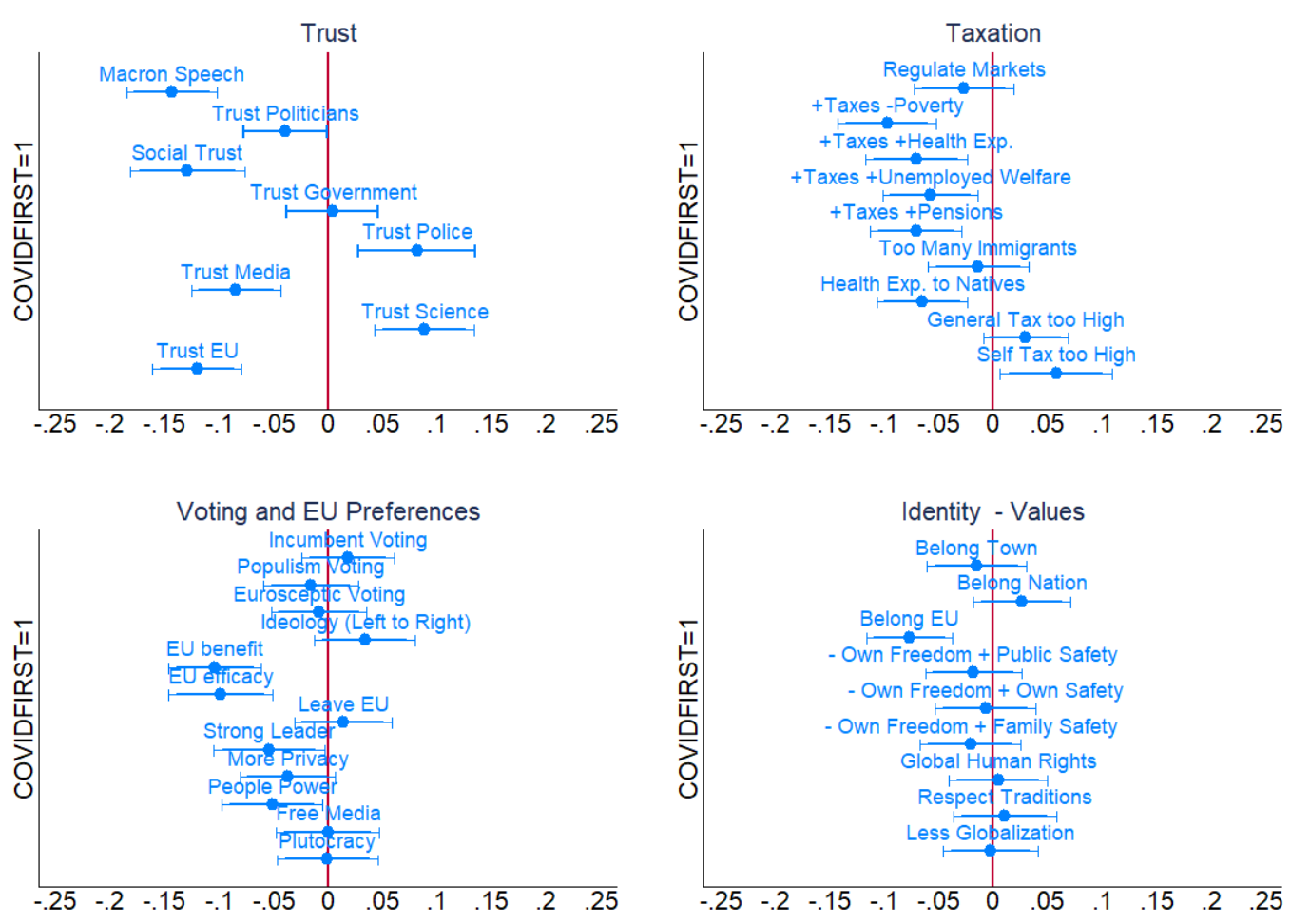

The figure shows the impact of COVIDFIRST on the four set of socio-political outcomes. For each coefficient, 95\% (delimited by horizontal bars) and 90\% (bold line) confidence intervals are shown.

\subsection{Economic dimension and 'rally around the flag'}

We now investigate how the three different health, economic and conflict sub-conditions differently contribute to the results presented in Section 5.1 to shed light on the mechanisms underlying our findings. In Figure 2, we first look at the effects of receiving questions highlighting only the health dimension of the crisis by only being asked about the health related experience of the COVID-19 epidemic. In this case, the comparison is with the Baseline group (i.e. individuals receiving outcome questions first, after which COVID-19 -related questions follow) as of model (2). The findings are mostly similar to the ones presented in Figure 1 with some exceptions: i) we do not find a negative effect on attitudes towards the individual fiscal burden; ii) we do not find any effect on populist attitudes; iii) we find a positive effect on support for political parties in 
the national government. These observations suggest that at least some of our findings are driven by the sub-treatments eliciting the economic and 'conflict' dimensions of the COVID-19 crisis.

In Figure 3, we focus on the effect of the economic dimension of the crisis. As already explained in Section 3, we add the economic dimension to the health. As of model (3), the comparison is between individuals receiving the Economic condition with those only receiving the Health condition. The latter thus serve as a baseline comparison. First, the economic condition appears to consistently shift trust attitudes to the left: the estimated coefficients are all negative, many significant at conventional levels. In line with a sharper decrease in trust towards institutions, we find lower attitudes towards giving up freedom in exchange for individual and public safety (bottom right panel). Second, in contrast with what was observed in the Health condition, individual and general tax burdens are perceived as excessive when the economic dimension of the COVID-19 epidemic is emphasised. Third, the bottom left panel shows a negative significant effect on support for incumbent parties and a negative (barely not statistically significant) effect on support for populist and Eurosceptic parties.

Figure 4 displays how the rhetoric highlighted in the Conflict sub-treatment impacts socio-political attitudes beyond the Health condition: in this case, the comparison is between individuals receiving Conflict condition with those receiving the Health condition as a baseline. Our focus here is on the 'rally around the flag' effect stressed by the media and politicians in the weeks immediately after the arrival of the epidemic in Europe. This condition shows remarkably little impact beyond that of the health intervention. The only striking difference concerns trust in science, as the conflict dimension has a much more positive effect than the simple health dimension ( 0.20 of a SD).

Overall, the results in this section show that the economic dimension seems to trigger additional and negative responses in terms of trust and welfare support, as well as in terms of approval for the ruling political parties. Conversely, the 'rally around the flag' treatment has limited effects in addition to the health dimension (except for trust in science).

As highlighted in the previous section, our findings of a 'disillusion' effect are attenuated among Spanish respondents. A possible explanation is that a positive 'rally around the flag' effect prevailed in this case. This is indeed what we find when we compare the effects of the conflict condition (Figure 4), distinguishing between Spain and the 
other three countries. Appendix Figure A5 shows very weak effects of this condition in Germany, Italy and the Netherlands; conversely, Appendix Figure A6 shows remarkably strong effects in Spain, in terms of i) general higher levels of trust (with a massive effect on trust in science, 0.40 of a SD) and EU preferences; ii) stronger attitudes of belonging to local, national and supra-national communities; iii) and higher demand for privacy and traditional values.

Figure 2: Effect of the Health condition compared to C
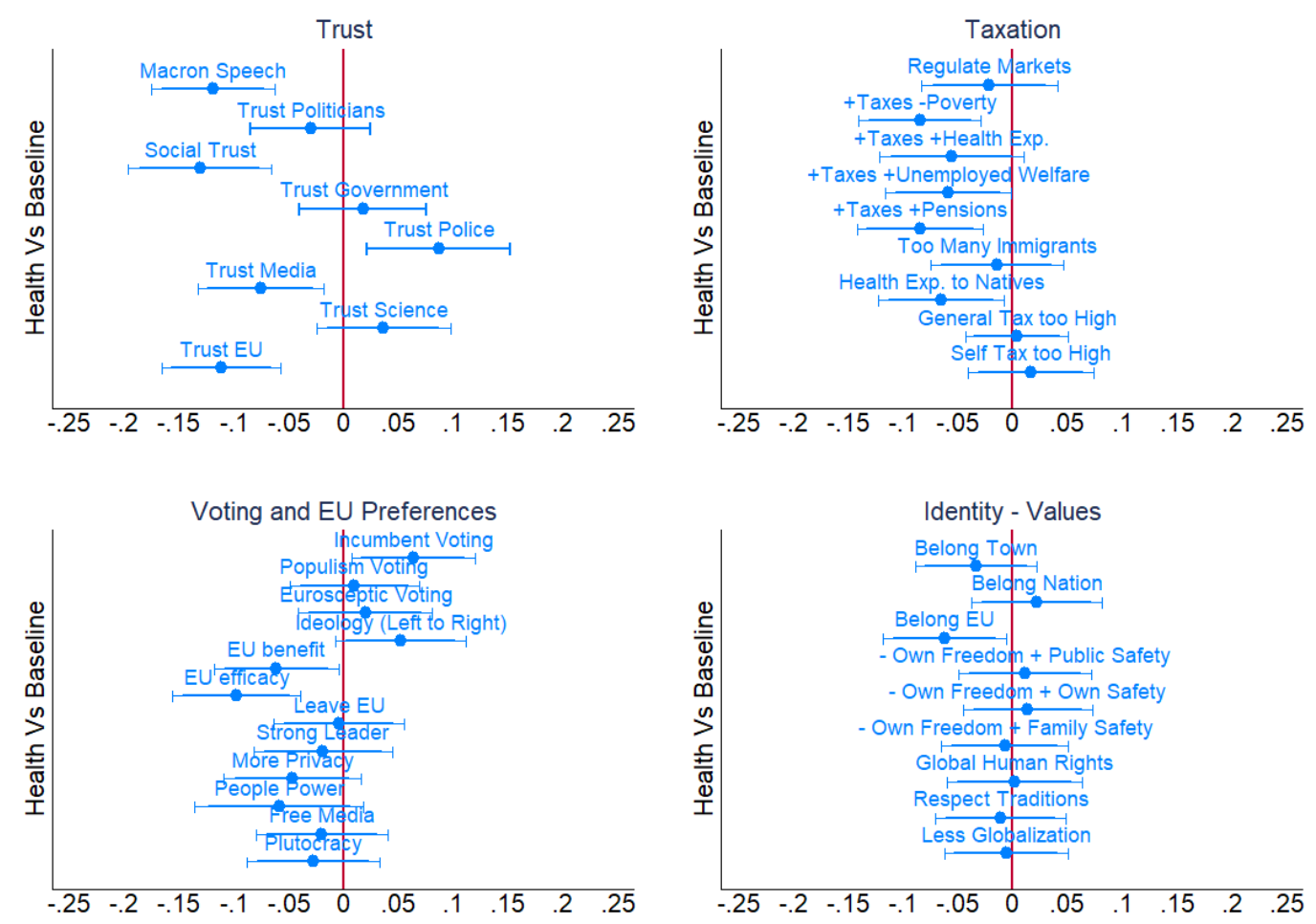

The figure shows the impact of the Health condition (COVID-19 health treatment) on the four set of socio-political outcomes. For each coefficient, 95\% (delimited by horizontal bars) and 90\% (bold line) confidence intervals are shown. 
Figure 3: Effect of the Economic condition compared to the Health condition
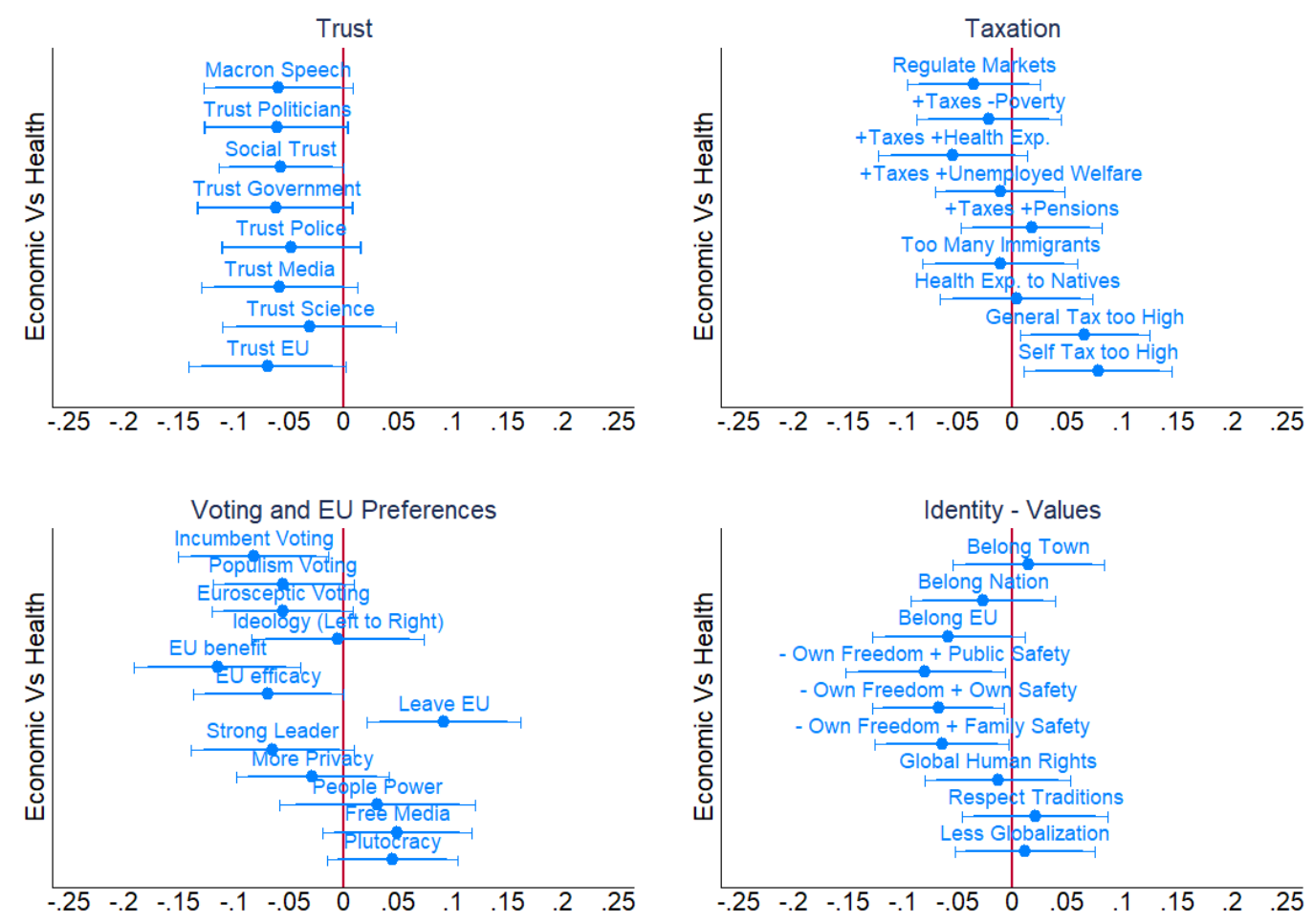

The figure shows the impact of the Economic condition (economic effects of COVID19) compared to the Health condition (COVID-19 health treatment) on the four set of socio-political outcomes. For each coefficient, $95 \%$ (delimited by horizontal bars) and $90 \%$ (bold line) confidence intervals are shown. 
Figure 4: Effect of the Conflict condition compared to the Health condition
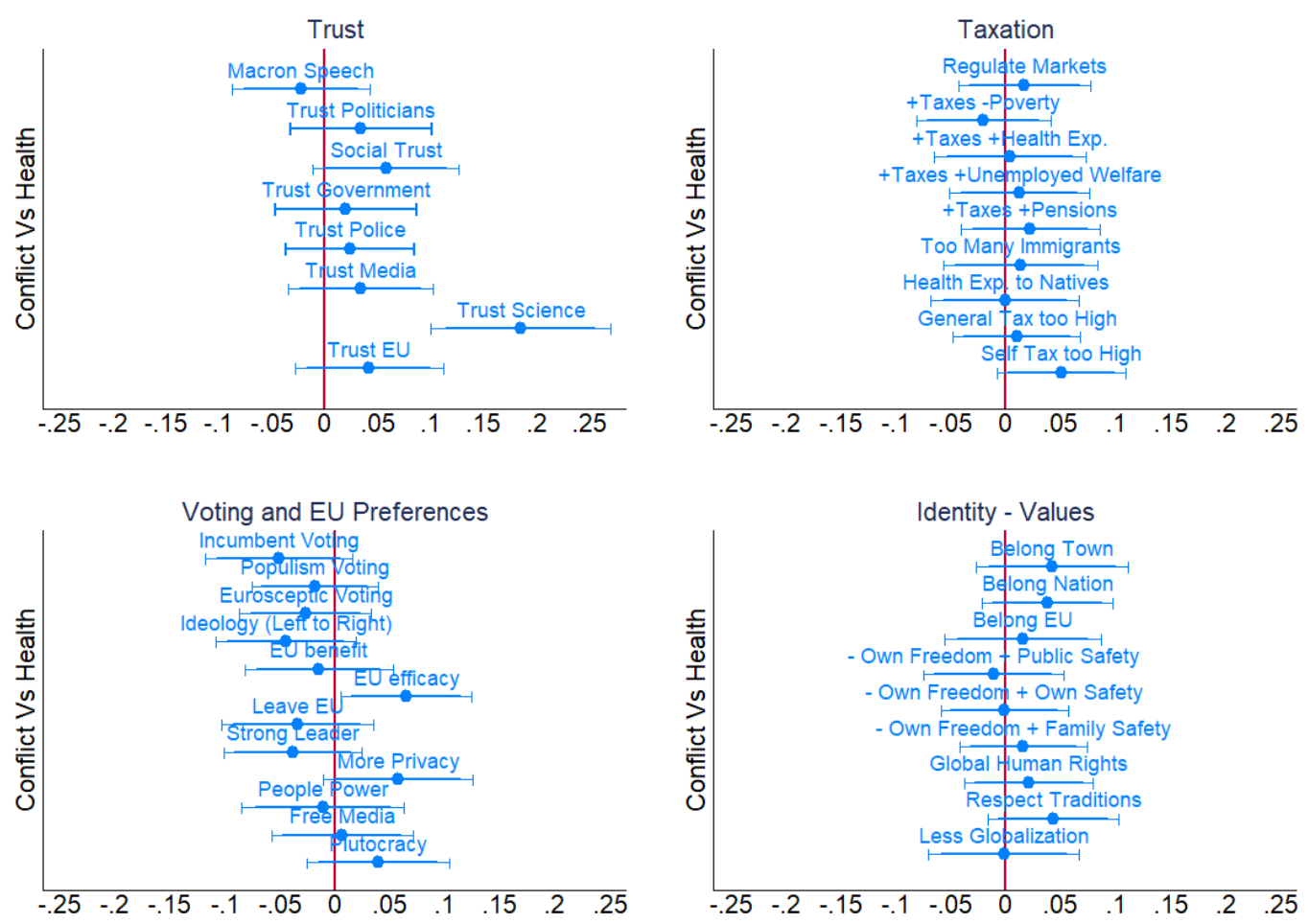

The figure shows the impact of the Conflict condition ('rally around the flag') compared to the Health condition (COVID-19 health treatment) on the four set of socio-political outcomes. For each coefficient, 95\% (delimited by horizontal bars) and $90 \%$ (bold line) confidence intervals are shown.

\subsection{COVID-19 and European's willingness to support the European Union}

It is worth spending some time on the performance of the behavioural (incentivised) measure of our respondents' willingness to engage in an action explicitly framed as supportive of European integration and its interpretation. As described in Section 3, the question "Macron Speech" asked the respondents whether they would be willing to spend five minutes of their time to read and review a text about the European integration process. As shown in Figure 1 a significantly lower proportion of respondents agrees to read the text when asked. We interpret this finding as evidence that focusing the respondents attention on the COVID-19 epidemic and on its dimensions here investigated leads to a decreased willingness to engage in an action supportive of European integration. In 
support of this interpretation, we present investigations of the behavioural regularities associated with the choice to read the text in Appendix E.

The results presented in Appendix $\mathrm{E}$ give us an indication that our behavioural outcome indeed captures a clean measure of willingness to engage in an action framed as supportive of the European integration process. We find no meaningful differences in the amount of time spent on the text screen and no differences in the distribution of scores assigned to the text across conditions and a weak though significant relationship between the amount of time spent on the text screen and the rating to it assigned by the respondent. We are therefore confident that the impacts of our conditions on the willingness to read and review the text are orthogonal to the respondents' underlying attitudes towards the European integration project.

\subsection{Real and perceived exposure to COVID-19 and compliance with lock-down rules}

As explained in Section 3, our baseline treatment includes an array of questions related to individuals' exposure to and experience of the COVID-19 epidemic (see Appendix F for the English questionnaire). In this section, we focus on the heterogeneous effects in regard to individuals' experiences with the COVID-19 19 and lockdown measures. These questions were by design asked to all the respondents in our study. We are interested in studying whether our findings are systematically heterogeneous with respect to individuals' experience with the COVID-19 epidemic.

These experiences can be divided into three groups: i) having contracted the virus or having someone close who has contracted the virus; ii) the individuals' level of compliance with the lock-down laws; and iii) the level of concern in relation to the virus. ${ }^{17}$ We label these groups Contracted, Compliance and Concerned respectively. For each group, we include all relevant questions in a factor analysis revealing the presence of a single factor upon which all elements load strongly (i.e. all factor loadings exceed 0.61). Each factor can be interpreted as a single variable summarising the information contained in each underlying variable. The factor variables are therefore increasing in whether someone: i) has contracted the virus and/or know someone who has contracted the virus; ii) has

\footnotetext{
${ }^{17}$ Specifically, i) includes questions on whether the respondent, someone in his/her family or someone (s)he knows, has contracted the virus; ii) includes replies on whether the respondent perceived social distancing rules as being too strict, kept social distancing and wore a mask; iii) includes statements on whether the respondent tried to get tested for COVID-19 and his/her self-reported level of concern about his/her health.
} 
complied with the lock-down rules; and iii) reports to be worried about the virus. ${ }^{18}$

The factor variable predicted values are then employed in the analysis of how the impact of COVIDFIRST varies along the Compliance, Concerned and Contracted dimensions. ${ }^{19}$ In Figures 5, 6 and 7 we report the results, which only display the interacted coefficients.

Figure 5 focuses on the interaction between COVIDFIRST and the level of compliance with the lock-down measures. Treated individuals with higher levels of compliance are more likely to trust institutions (i.e. politicians, the government and science) and perceive their individual and the general tax burden as less problematic, while they trust other people less. The former could again be interpreted as a proxy of the 'rally around the flag' effect, in the form of cooperation with the government and a higher approval of the policy implemented to counter the health crisis. The latter effect could be because those respecting the rules the most also perceive others around them as respecting the rules less, so that the relational and conditional nature of trust - as described by Levi and Stoker (2000) - is eroded.

Among those who are concerned about their health, a similar argument can be made. Figure 6 shows that Concerned $\times$ COVIDFIRST slightly boosts levels of institutional trust as well, but mostly marks remarkably higher support for taxation and welfare programs, as well as market regulation. Social trust is lower also for this group, which is possibly due to mounting stress levels as pointed out by Potts et al. (2019).

From Figure 7 we learn that Contracted $\times$ COVIDFIRST leads to similar conclusions for those who have been in close contact with the virus, with a significantly higher support to raise taxes to finance public health expenditure. A remarkable exception is the neutral effect on social trust. This could mean that perceived risk plays a bigger part in trusting others, rather than actual 'realised' risks of catching the virus, as also argued by Brück et al. (2020).

\footnotetext{
${ }^{18}$ Details about the factor analyses can be found in Appendix D.

${ }^{19}$ Tables B33 to B44 in Appendix B.4 shows that the replies to the questions included into Compliance, Concerned and Contracted, and are exogenous to the COVIDFIRST condition.
} 
Figure 5: Interaction effects: compliance
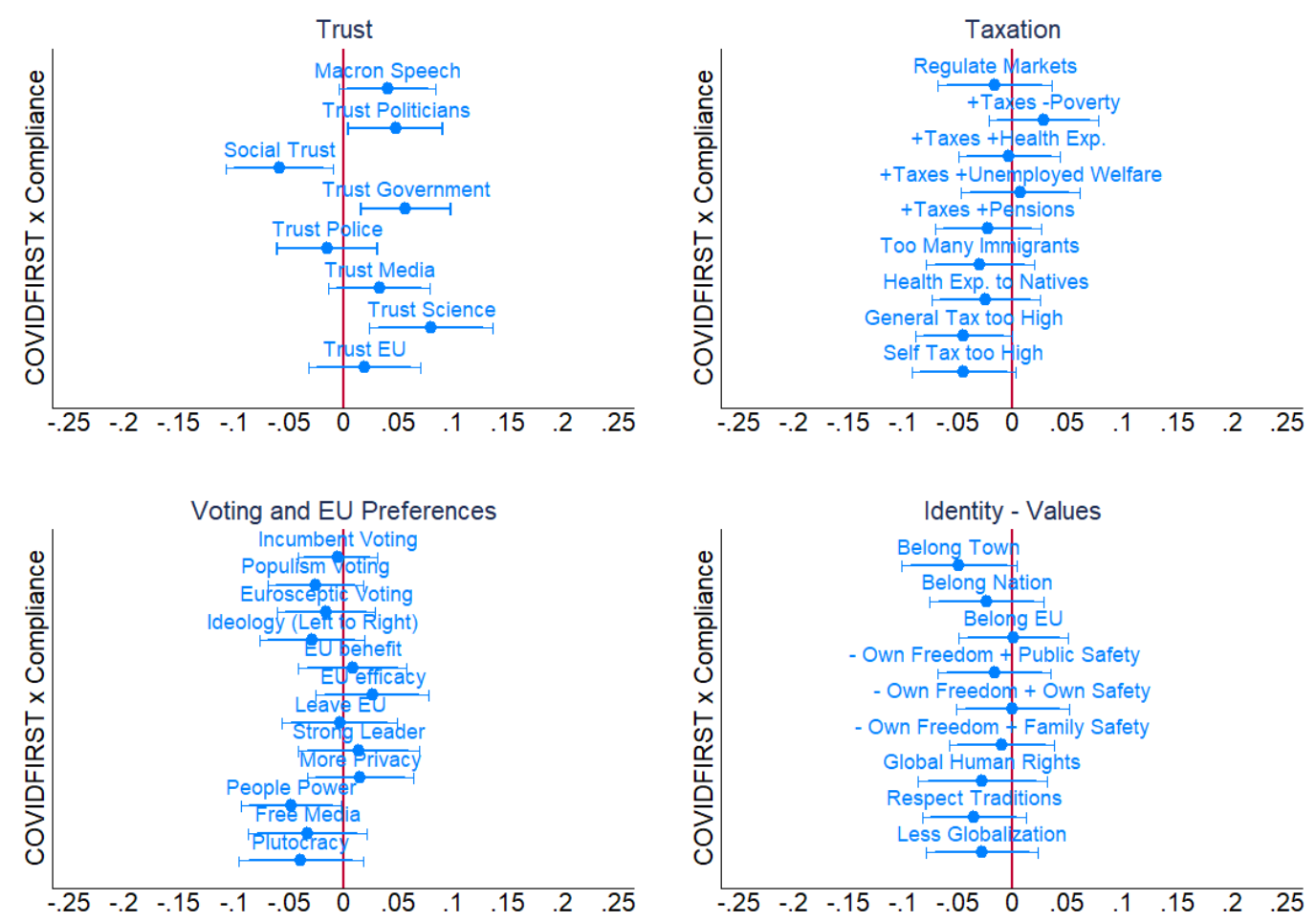

The figure shows the impact of the interaction COVIDFIRST $\times$ Compliance on the four set of socio-political outcomes. For each coefficient, 95\% (delimited by horizontal bars) and 90\% (bold line) confidence intervals are shown. 
Figure 6: Interaction effects: health concerns
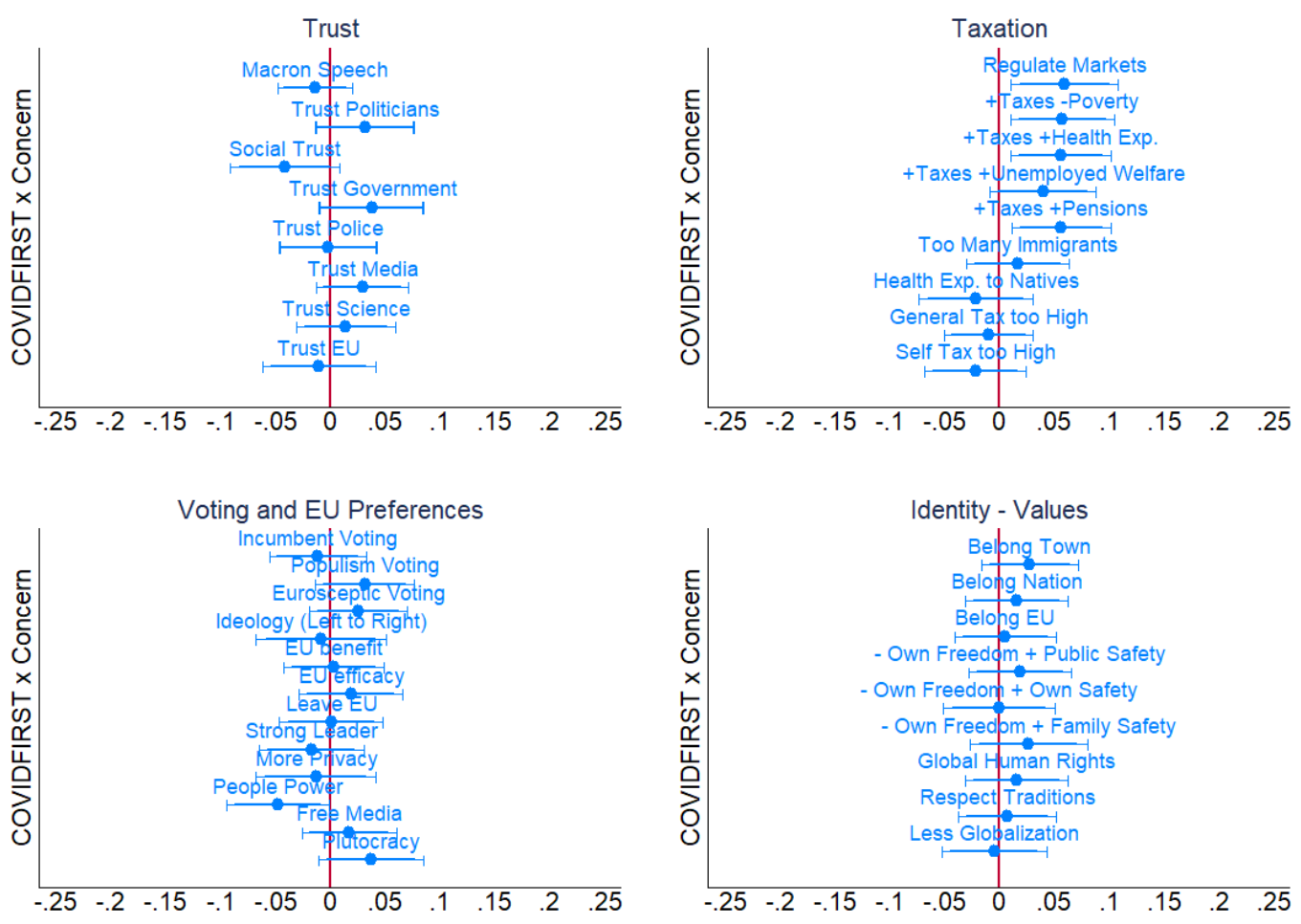

The figure shows the impact of the interaction COVIDFIRST $\times$ Concern on the four set of socio-political outcomes. For each coefficient, 95\% (delimited by horizontal bars) and 90\% (bold line) confidence intervals are shown. 
Figure 7: Interaction effects: exposure to the virus
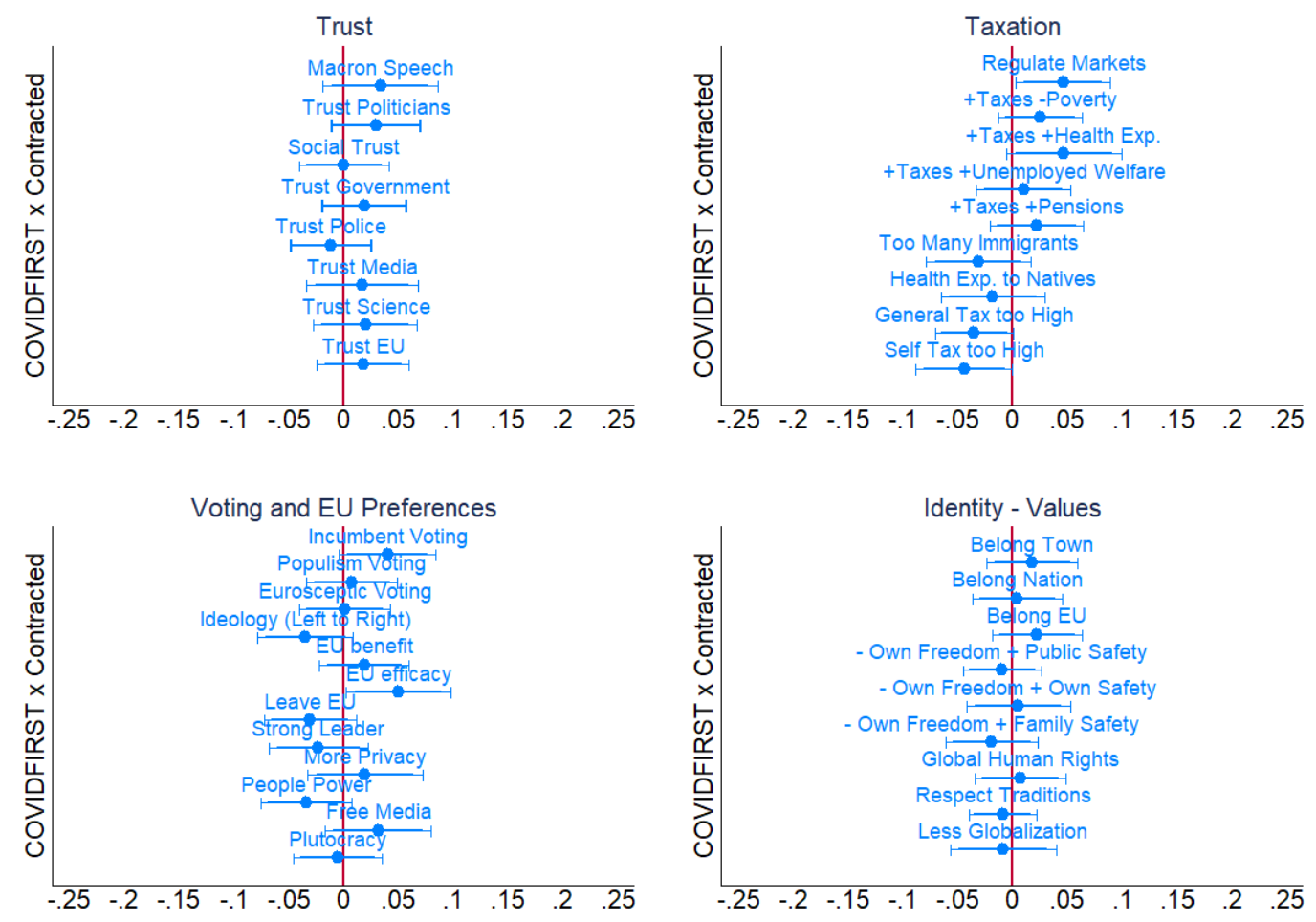

The figure shows the impact of the interaction COVIDFIRST $\times$ Contracted on the four set of socio-political outcomes. For each coefficient, 95\% (delimited by horizontal bars) and $90 \%$ (bold line) confidence intervals are shown.

\section{Conclusions}

In this paper we show that simply priming people to think about COVID-19 can shape their socio-political attitudes. More specifically, their view about their government, their politics, their institutions in general as well as the design of their welfare state seem to be affected, along with many other dimensions of their (political) life. We do so by randomising the order in which a block of survey questions - eliciting people's experience with the COVID-19 crisis - are posed, as opposed to a block of questions eliciting their political attitudes.

We find significant treatment effects in all of our outcome categories, indicating that the crisis has brought about severe drops in interpersonal and institutional trust, as well as lower support for the EU and social welfare spending financed by taxes. We also found 
that priming with the purely economic effects of the crisis shapes people's attitudes quite differently than priming only on the health or 'conflict' dimensions of the pandemic, with lower levels of institutional support and trust compounded by economic insecurity. A rallying effect around (scientific) expertise combined with populist policies losing ground forms the other side of this coin, and hints at a rising demand for competent leadership.

Of course, our results should first and foremost be interpreted as a shock, diverging from existing trends. Whether we have in fact uncovered a critical juncture setting these trends on an entirely different path, can only be ascertained by conducting followup waves of our survey experiment. Depending on how governments will manage the economic recovery and/or a possible resurgence of the virus will be a crucial factor here. In any case it will be interesting to see whether the rising demand for competent leaders and policies we uncover is met in the future, or whether the 'disillusion' effect our study also brings to the surface will eventually be channeled into increased populist support if the opportunity is missed.

\section{References}

Aassve, A., Alfani, G., Gandolfi, F., Le Moglie, M., et al. (2020). Epidemics and trust: the case of the spanish flu. Technical report.

Achen, C. H. and Bartels, L. M. (2004). Blind retrospection: Electoral responses to drought, flu, and shark attacks.

Achen, C. H. and Bartels, L. M. (2017). Democracy for realists: Why elections do not produce responsive government, volume 4. Princeton University Press.

Aksoy, C. G., Eichengreen, B., Saka, O., et al. (2020). The political scar of epidemics. Technical report, Institute of Labor Economics (IZA).

Alesina, A., Miano, A., and Stantcheva, S. (2018). Immigration and Redistribution. Working Paper 24733, National Bureau of Economic Research.

Algan, Y., Guriev, S., Papaioannou, E., and Passari, E. (2017). The european trust crisis and the rise of populism. Brookings Papers on Economic Activity, 2017(2):309-400.

Amat, F., Arenas, A., Falcó-Gimeno, A., and Muñoz, J. (2020). Pandemics meet democracy. experimental evidence from the covid-19 crisis in spain. 
Ariely, G. (2017). Why does patriotism prevail? contextual explanations of patriotism across countries. Identities, 24(3):351-377.

Bækgaard, M., Christensen, J., Madsen, J. K., and Mikkelsen, K. S. (2020). Rallying around the flag in times of covid-19: Societal lockdown and trust in democratic institutions. Journal of Behavioral Public Administration, 3(2).

Bartos, V., Bauer, M., Cahlíková, J., and Chytilová, J. (2020). Covid-19 crisis fuels hostility against foreigners.

Bauer, M., Blattman, C., Chytilová, J., Henrich, J., Miguel, E., and Mitts, T. (2016). Can war foster cooperation? Journal of Economic Perspectives, 30(3):249-74.

Bechtel, M. M. and Hainmueller, J. (2011). How lasting is voter gratitude? an analysis of the short-and long-term electoral returns to beneficial policy. American Journal of Political Science, 55(4):852-868.

Blickle, K. (2020). Pandemics change cities: Municipal spending and voter extremism in germany, 1918-1933. FRB of New York Staff Report, (921).

Bol, D., Giani, M., Blais, A., and Loewen, P. J. (2020). The effect of covid-19 lockdowns on political support: Some good news for democracy? European Journal of Political Research.

Brodeur, A., Gray, D. M., Islam, A., and Bhuiyan, S. (2020). A literature review of the economics of covid-19.

Brück, T., Ferguson, N., Justino, P., and Stojetz, W. (2020). Trust in the time of corona.

Daniele, G. and Geys, B. (2015). Interpersonal trust and welfare state support. European Journal of Political Economy, 39:1-12.

de Quidt, J., Johannes, H., and Christopher, R. (2018). Measuring and Bounding Experimenter Demand. American Economic Review, 108(11):64.

Dellavigna, S., List, J. A., Malmendier, U., and Rao, G. (2017). Voting to Tell Others. The Review of Economic Studies, 84(1):143-181. Publisher: Oxford Academic.

Durante, R., Gulino, G., et al. (2020). Asocial capital: Civic culture and social distancing during covid-19. 
Dustmann, C., Eichengreen, B., Otten, S., Sapir, A., Tabellini, G., and Zoega, G. (2017). Europe's trust deficit. Causes and Remedies. London: Centre for Economic Policy Research.

Fetzer, T., Hensel, L., Hermle, J., and Roth, C. (2020). Coronavirus Perceptions and Economic Anxiety. The Review of Economics and Statistics, pages 1-36. Publisher: MIT Press.

Foremny, D., Sorribas-Navarro, P., and Vall Castelló, J. (2020). Living at the peak: Health and public finance during the covid-19 pandemic. Available at SSRN 3578483.

Frieden, J. (2016). The crisis, the public, and the future of european integration. After the crisis: Reform, recovery, and growth in Europe, pages 146-70.

Gasper, J. T. and Reeves, A. (2011). Make it rain? retrospection and the attentive electorate in the context of natural disasters. American Journal of Political Science, $55(2): 340-355$.

Gibler, D. M., Hutchison, M. L., and Miller, S. V. (2012). Individual identity attachments and international conflict: The importance of territorial threat. Comparative Political Studies, 45(12):1655-1683.

Grossman, G., Kim, S., Rexer, J., and Thirumurthy, H. (2020). Political partisanship influences behavioral responses to governors' recommendations for covid-19 prevention in the united states. Available at SSRN 3578695.

Guiso, L., Herrera, H., Morelli, M., and Sonno, T. (2020). Economic insecurity and the demand of populism in europe. Einaudi Institute for Economics and Finance.

Healy, A. and Malhotra, N. (2009). Myopic voters and natural disaster policy. American Political Science Review, pages 387-406.

Heersink, B., Peterson, B. D., and Jenkins, J. A. (2017). Disasters and elections: Estimating the net effect of damage and relief in historical perspective. Political Analysis, $25(2): 260-268$.

Hernández, E. and Kriesi, H. (2016). Turning your back on the eu. the role of eurosceptic parties in the 2014 european parliament elections. Electoral Studies, 44:515-524. 
Hetherington, M. J. and Nelson, M. (2003). Anatomy of a rally effect: George w. bush and the war on terrorism. PS: Political Science and Politics, 36(1):37-42.

Kevins, A. (2019). Dualized trust: risk, social trust and the welfare state. SocioEconomic Review, 17(4):875-897.

Kushner Gadarian, S., Goodman, S. W., and Pepinsky, T. B. (2020). Partisanship, health behavior, and policy attitudes in the early stages of the covid-19 pandemic. Health Behavior, and Policy Attitudes in the Early Stages of the COVID-19 Pandemic (March 27, 2020).

Levi, M. and Stoker, L. (2000). Political trust and trustworthiness. Annual review of political science, $3(1): 475-507$.

Margalit, Y. (2019). Political responses to economic shocks. Annual Review of Political Science.

Merkley, E., Bridgman, A., Loewen, P. J., Owen, T., Ruths, D., and Zhilin, O. (2020). A rare moment of cross-partisan consensus: Elite and public response to the covid19 pandemic in canada. Canadian Journal of Political Science/Revue canadienne de science politique, pages 1-8.

Owens, L. A. and Cook, K. S. (2013). The effects of local economic conditions on confidence in key institutions and interpersonal trust after the great recession. The annals of the American academy of political and social science, 650(1):274-298.

Potts, S. R., McCuddy, W. T., Jayan, D., and Porcelli, A. J. (2019). To trust, or not to trust? individual differences in physiological reactivity predict trust under acute stress. Psychoneuroendocrinology, 100:75-84.

Stevenson, B. and Wolfers, J. (2011). Trust in public institutions over the business cycle. American Economic Review, 101(3):281-87.

Zizzo, D. J. (2010). Experimenter demand effects in economic experiments. Experimental Economics, 13(1):75-98. 


\section{Appendix}

\section{A Results by country}

Figure A1: Effect of the intervention in Germany
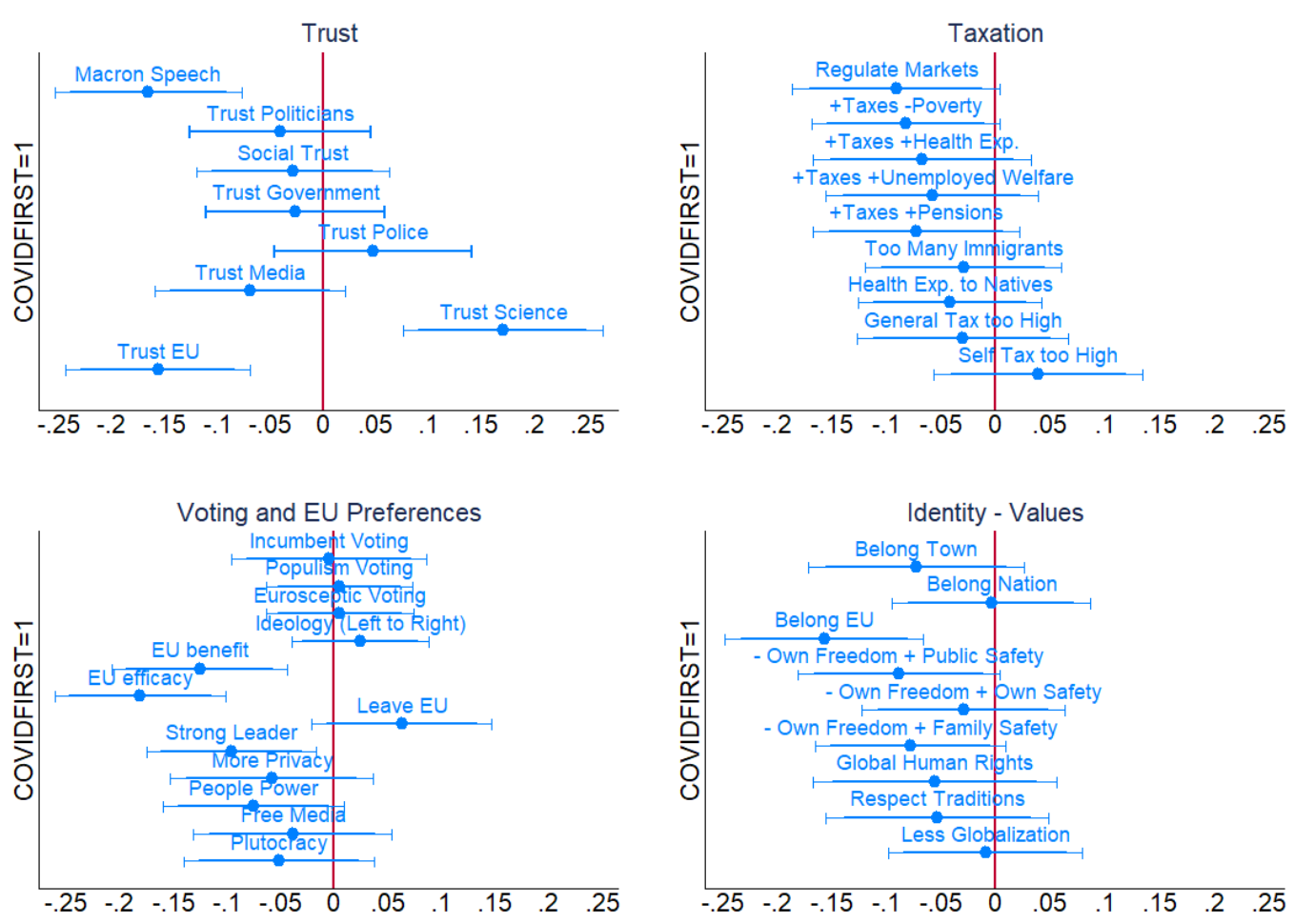

The figure shows the impact of COVIDFIRST on the four set of socio-political outcomes in Germany. For each coefficient, 95\% (delimited by horizontal bars) and 90\% (bold line) confidence intervals are shown. 
Figure A2: Effect of the intervention in Italy
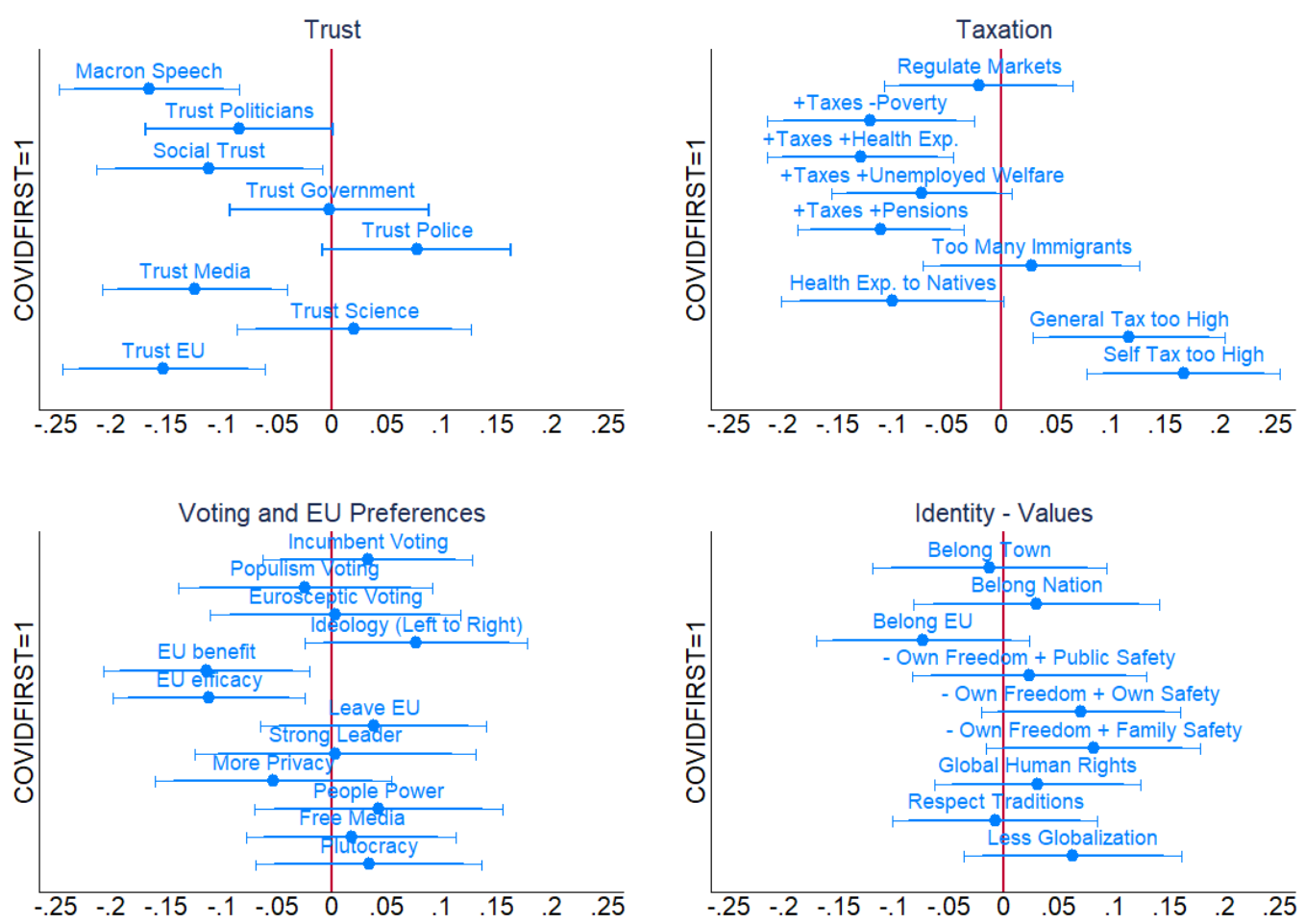

The figure shows the impact of COVIDFIRST on the four set of socio-political outcomes in Italy. For each coefficient, 95\% (delimited by horizontal bars) and $90 \%$ (bold line) confidence intervals are shown. 
Figure A3: Effect of the intervention in the Netherlands
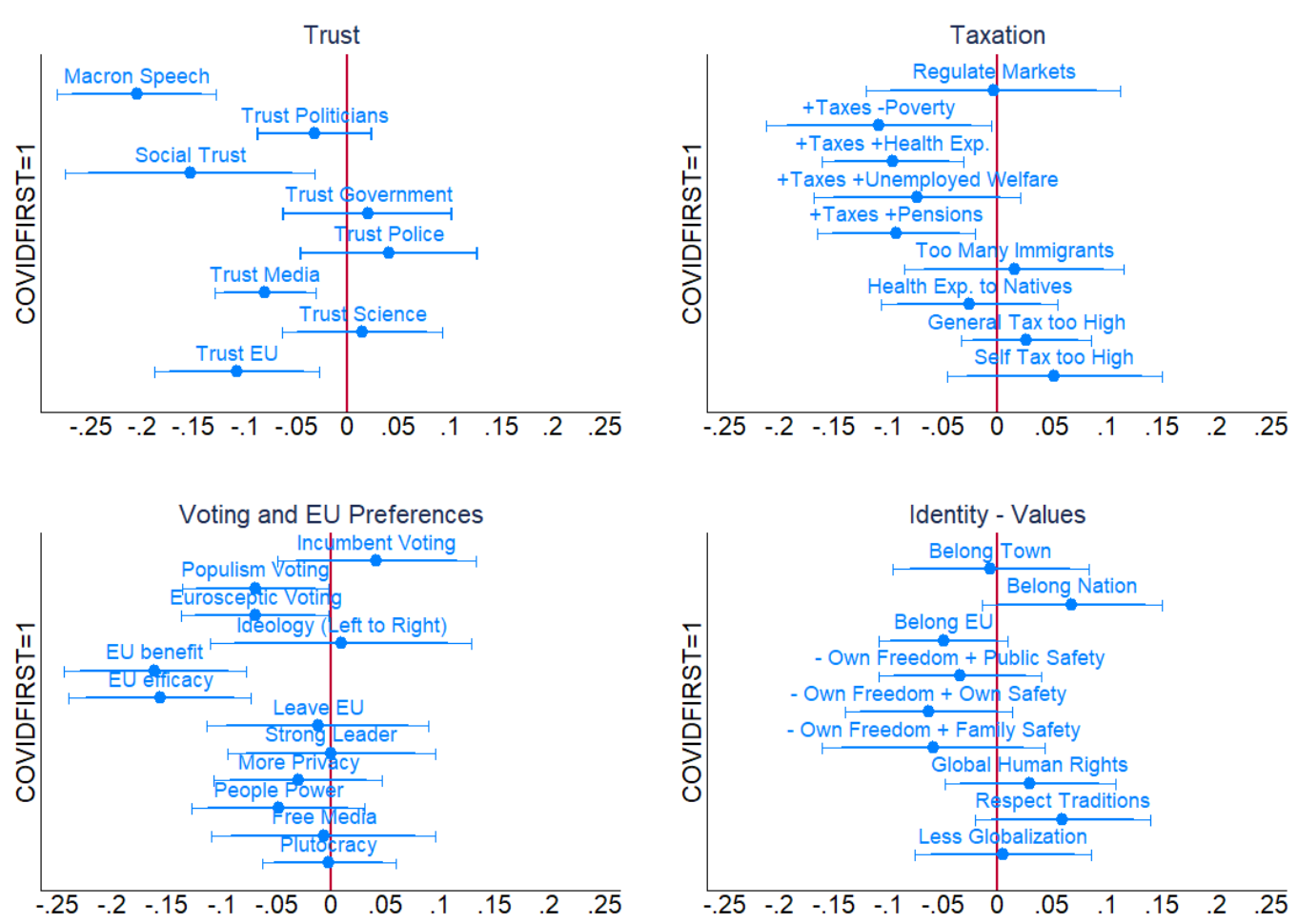

The figure shows the impact of COVIDFIRST on the four set of socio-political outcomes in the Netherlands. For each coefficient, 95\% (delimited by horizontal bars) and $90 \%$ (bold line) confidence intervals are shown. 
Figure A4: Effect of the intervention in Spain
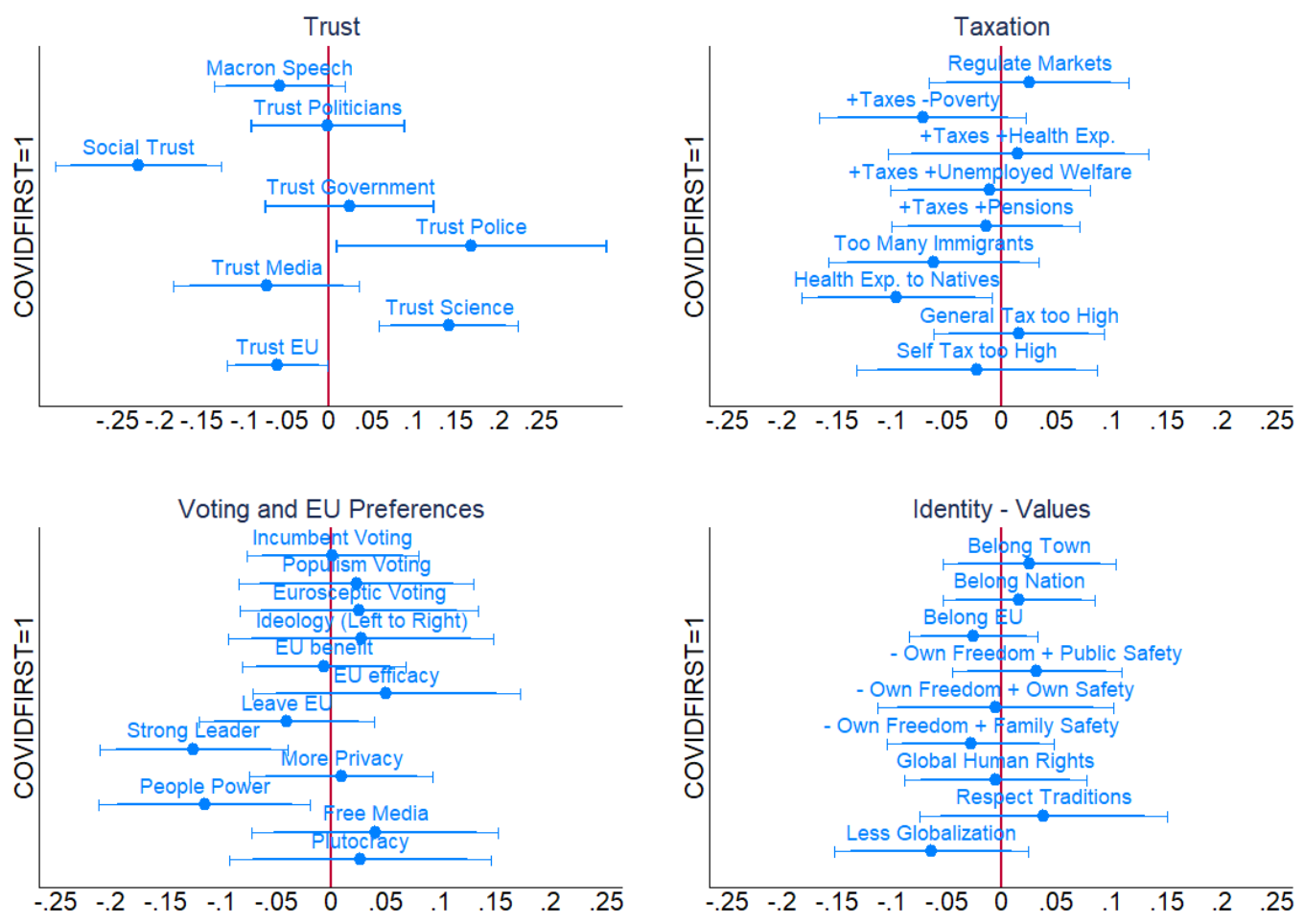

The figure shows the impact of COVIDFIRST on the four set of socio-political outcomes in Spain. For each coefficient, 95\% (delimited by horizontal bars) and 90\% (bold line) confidence intervals are shown. 
Figure A5: Effect of the Conflict condition in Germany, Italy and the Netherlands
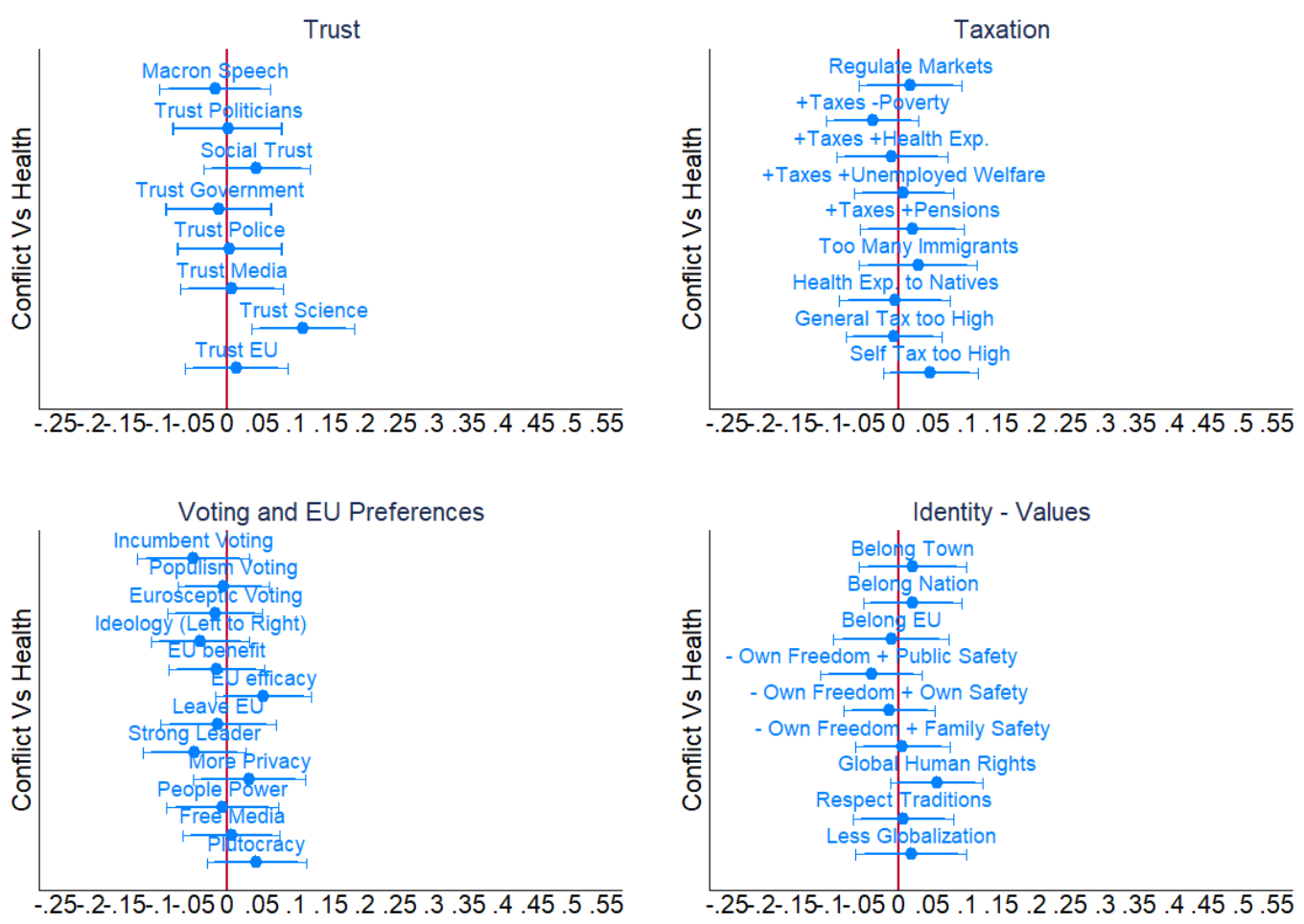

The figure shows the impact of the Conflict condition compared to the Health condition (COVID-19 health treatment) on the four set of socio-political outcomes among respondents in Germany, Italy and the Netherlands. For each coefficient, $95 \%$ (delimited by horizontal bars) and 90\% (bold line) confidence intervals are shown. 
Figure A6: Effect of the Conflict condition in Spain
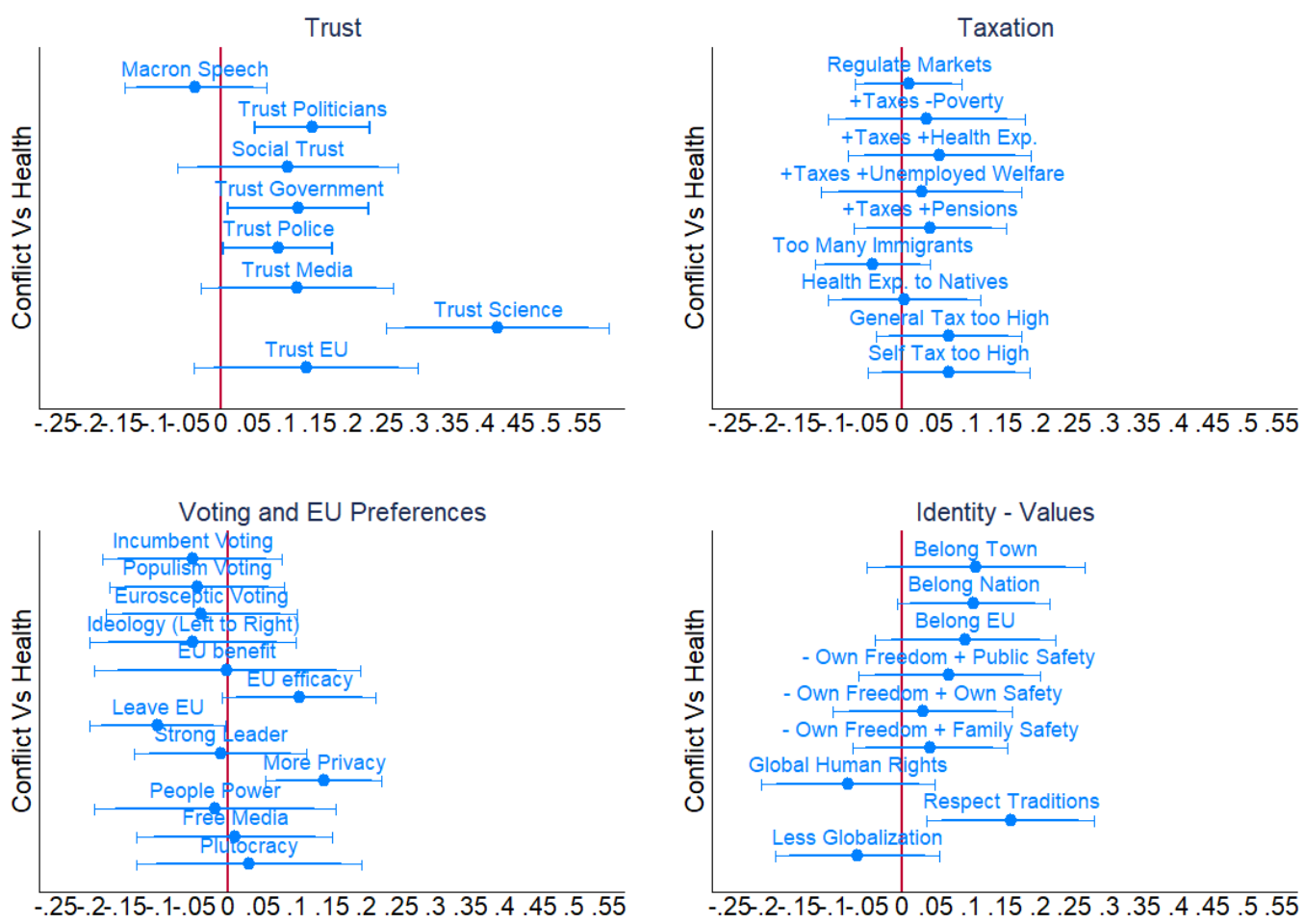

The figure shows the impact of the Conflict condition compared to the Health condition (COVID-19 health treatment) on the four set of socio-political outcomes among Spanish respondents. For each coefficient, 95\% (delimited by horizontal bars) and $90 \%$ (bold line) confidence intervals are shown. 


\section{B Tables}

\section{B.1 Pooled analyses: COVIDFIRST vs Baseline}

Table B1: Effects of Covidfirst vs Baseline - Trust outcomes

\begin{tabular}{|c|c|c|c|c|c|c|c|c|}
\hline & $\begin{array}{l}\text { Macron } \\
\text { Speech }\end{array}$ & $\begin{array}{c}\text { Trust } \\
\text { Politicians } \\
\end{array}$ & $\begin{array}{l}\text { Social } \\
\text { Trust }\end{array}$ & $\begin{array}{c}\text { Trust } \\
\text { Government }\end{array}$ & $\begin{array}{l}\text { Trust } \\
\text { Police }\end{array}$ & $\begin{array}{l}\text { Trust } \\
\text { Media }\end{array}$ & $\begin{array}{c}\text { Trust } \\
\text { Science }\end{array}$ & $\begin{array}{c}\text { Trust } \\
\text { EU }\end{array}$ \\
\hline Covidfirst & $\begin{array}{c}-0.143^{* * *} \\
(0.0199)\end{array}$ & $\begin{array}{c}-0.0389^{* *} \\
(0.0195)\end{array}$ & $\begin{array}{c}-0.128^{* * *} \\
(0.0282)\end{array}$ & $\begin{array}{l}0.00441 \\
(0.0229)\end{array}$ & $\begin{array}{c}0.0817^{* * *} \\
(0.0272)\end{array}$ & $\begin{array}{c}-0.0842^{* * *} \\
(0.0210)\end{array}$ & $\begin{array}{c}0.0886^{* * *} \\
(0.0211)\end{array}$ & $\begin{array}{c}-0.120^{* * *} \\
(0.0199)\end{array}$ \\
\hline Observations & 8,235 & 8,235 & 8,235 & 8,235 & 8,235 & 8,235 & 8,235 & 8,235 \\
\hline R-squared & 0.063 & 0.183 & 0.063 & 0.119 & 0.034 & 0.144 & 0.046 & 0.027 \\
\hline
\end{tabular}

The table presents estimates from OLS models. The outcome variables are stated in the first row. The sample compares the COVIDFIRST condition to the Baseline group. Controls include gender, age groups, employment status, education, immigrant status, family status and number of family members, equivalised household income (coded into five quantiles), a dummy to define the position of the Macron Speech question (see Section 3.1 for more details) and country fixed effects. All controls are omitted to enhance readability. Robust standard errors clustered at the province level are in parentheses. ${ }^{*} p<0.1 ;{ }^{* *} p<0.05 ;{ }^{* * *} p<0.01$

Table B2: Effects of Covidfirst vs Baseline - Taxation outcomes

\begin{tabular}{|c|c|c|c|c|c|c|c|c|c|}
\hline & $\begin{array}{l}\text { Regulate } \\
\text { Markets }\end{array}$ & $\begin{array}{l}+ \text { Taxes } \\
\text {-Poverty }\end{array}$ & $\begin{array}{c}\text { + Taxes } \\
+ \text { Health Exp. }\end{array}$ & $\begin{array}{c}\text { +Taxes } \\
\text { +Unemp. Welf. }\end{array}$ & $\begin{array}{c}\text { + Taxes } \\
+ \text { Pensions }\end{array}$ & $\begin{array}{c}\text { Too Many } \\
\text { Immigrants }\end{array}$ & $\begin{array}{c}\text { Health Exp. } \\
\text { to Natives }\end{array}$ & $\begin{array}{c}\text { General Tax } \\
\text { too High }\end{array}$ & $\begin{array}{l}\text { Self Tax } \\
\text { too High }\end{array}$ \\
\hline Covidfirst & $\begin{array}{c}-0.0269 \\
(0.0232)\end{array}$ & $\begin{array}{c}-0.0974^{* * *} \\
(0.0219)\end{array}$ & $\begin{array}{c}-0.0705^{* * *} \\
(0.0204)\end{array}$ & $\begin{array}{c}-0.0578^{* * *} \\
(0.0210)\end{array}$ & $\begin{array}{c}-0.0707^{* * *} \\
(0.0187)\end{array}$ & $\begin{array}{c}-0.0138 \\
(0.0253)\end{array}$ & $\begin{array}{c}-0.0653^{* * *} \\
(0.0205)\end{array}$ & $\begin{array}{c}0.0297 \\
(0.0200)\end{array}$ & $\begin{array}{c}0.0581^{*} \\
(0.0296)\end{array}$ \\
\hline Observations & 8,235 & 8,235 & 8,235 & 8,235 & 8,235 & 8,235 & 8,235 & 8,235 & 8,235 \\
\hline R-squared & 0.072 & 0.016 & 0.052 & 0.054 & 0.046 & 0.027 & 0.019 & 0.124 & 0.106 \\
\hline
\end{tabular}

The table presents estimates from OLS models. The outcome variables are stated in the first row. The sample compares the COVIDFIRST condition to the Baseline group. Controls include gender, age groups, employment status, education, immigrant status, family status and number of family members, equivalised household income (coded into five quantiles), a dummy to define the position of the Macron Speech question (see Section 3.1 for more details) and country fixed effects. All controls are omitted to enhance readability. Robust standard errors clustered at the province level are in parentheses. ${ }^{*} p<0.1 ;{ }^{* *} p<0.05 ; * * * p<0.01$

Table B3: Effects of Covidfirst vs Baseline - Voting outcomes

\begin{tabular}{|c|c|c|c|c|c|c|c|c|c|c|c|c|}
\hline & $\begin{array}{c}\text { Incumbent } \\
\text { Voting }\end{array}$ & $\begin{array}{c}\text { Populism } \\
\text { Voting }\end{array}$ & $\begin{array}{c}\text { Euroscept. } \\
\text { Voting }\end{array}$ & $\begin{array}{c}\text { Ideology } \\
\text { Left/right }\end{array}$ & $\begin{array}{c}\text { EU } \\
\text { benefit }\end{array}$ & $\begin{array}{c}\text { EU } \\
\text { efficacy }\end{array}$ & $\begin{array}{c}\text { Leave } \\
\text { EU }\end{array}$ & $\begin{array}{l}\text { Strong } \\
\text { Leader }\end{array}$ & $\begin{array}{c}\text { More } \\
\text { Privacy }\end{array}$ & $\begin{array}{l}\text { People } \\
\text { Power }\end{array}$ & $\begin{array}{c}\text { Free } \\
\text { Media }\end{array}$ & Plutocra. \\
\hline Covidfirst & $\begin{array}{c}0.0183 \\
(0.0216)\end{array}$ & $\begin{array}{l}-0.0154 \\
(0.0220)\end{array}$ & $\begin{array}{c}-0.00823 \\
(0.0223)\end{array}$ & $\begin{array}{c}0.0339 \\
(0.0236)\end{array}$ & $\begin{array}{c}-0.103^{* * *} \\
(0.0216)\end{array}$ & $\begin{array}{c}-0.0983^{* * *} \\
(0.0243)\end{array}$ & $\begin{array}{c}0.0134 \\
(0.0227)\end{array}$ & $\begin{array}{c}-0.0545^{* *} \\
(0.0259)\end{array}$ & $\begin{array}{c}-0.0376^{*} \\
(0.0223)\end{array}$ & $\begin{array}{c}-0.0515^{* *} \\
(0.0235)\end{array}$ & $\begin{array}{c}-0.000363 \\
(0.0239)\end{array}$ & $\begin{array}{c}-0.000523 \\
(0.0236)\end{array}$ \\
\hline Observations & 8,235 & 8,235 & 8,235 & 8,235 & 8,235 & 8,235 & 8,235 & 8,235 & 8,235 & 8,235 & 8,235 & 8,235 \\
\hline R-squared & 0.015 & 0.083 & 0.064 & 0.053 & 0.069 & 0.058 & 0.042 & 0.026 & 0.037 & 0.041 & 0.078 & 0.045 \\
\hline
\end{tabular}

The table presents estimates from OLS models. The outcome variables are stated in the first row. The sample compares the COVIDFIRST condition to the Baseline group. Controls include gender, age groups, employment status, education, immigrant status, family status and number of family members, equivalised household income (coded into five quantiles), a dummy to define the position of the Macron Speech question (see Section 3.1 for more details) and country fixed effects. All controls are omitted to enhance readability. Robust standard errors clustered at the province level are in parentheses. ${ }^{*} p<0.1 ;{ }^{* *} p<0.05 ;{ }^{* * *} p<0.01$ 
Table B4: Effects of Covidfirst vs Baseline - Identity outcomes

\begin{tabular}{lccccccccc}
\hline & $\begin{array}{c}\text { Belong } \\
\text { Town }\end{array}$ & $\begin{array}{c}\text { Belong } \\
\text { Nation }\end{array}$ & $\begin{array}{c}\text { Belong } \\
\mathrm{EU}\end{array}$ & $\begin{array}{c}\text { - Own Freedom } \\
\text { + Public Safety }\end{array}$ & $\begin{array}{c}\text { - Own Freedom } \\
\text { + Own Safety }\end{array}$ & $\begin{array}{c}\text { - Own Freedom } \\
\text { + Family Safety }\end{array}$ & $\begin{array}{c}\text { Global Human } \\
\text { Rights }\end{array}$ & $\begin{array}{c}\text { Respect } \\
\text { Traditions }\end{array}$ & $\begin{array}{c}\text { Less } \\
\text { Globalization }\end{array}$ \\
\hline \multirow{2}{*}{ Covidfirst } & -0.0151 & 0.0263 & $-0.0763^{* * *}$ & -0.0182 & -0.00709 & -0.0211 & 0.00470 & 0.0104 & -0.00287 \\
& $(0.0241)$ & $(0.0229)$ & $(0.0196)$ & $(0.0226)$ & $(0.0212)$ & $(0.0216)$ & $(0.0234)$ & $(0.0238)$ & $(0.0231)$ \\
& & & & & & & & & \\
Observations & 8,235 & 8,235 & 8,235 & 8,235 & 8,235 & 8,235 & 8,235 & 8,235 \\
R-squared & 0.030 & 0.028 & 0.037 & 0.010 & 0.016 & 0.026 & 0.031 & 0.052 \\
\hline
\end{tabular}

The table presents estimates from OLS models. The outcome variables are stated in the first row. The sample compares the COVIDFIRST condition to the Baseline group. Controls include gender, age groups, employment status, education, immigrant status, family status and number of family members, equivalised household income (coded into five quantiles), a dummy to define enhance readability. Robust standard errors clustered at the province level are in parentheses. ${ }^{*} p<0.1 ; * * p<0.05 ; * * * p<0.01$ 


\section{B.2 Condition comparisons}

\section{B.2.1 Health vs Baseline}

Table B5: Effects of Health vs the Baseline: Trust outcomes

\begin{tabular}{lcccccccc}
\hline & $\begin{array}{c}\text { Macron } \\
\text { Speech }\end{array}$ & $\begin{array}{c}\text { Trust } \\
\text { Politicians }\end{array}$ & $\begin{array}{c}\text { Social } \\
\text { Trust }\end{array}$ & $\begin{array}{c}\text { Trust } \\
\text { Government }\end{array}$ & $\begin{array}{c}\text { Trust } \\
\text { Police }\end{array}$ & $\begin{array}{c}\text { Trust } \\
\text { Media }\end{array}$ & $\begin{array}{c}\text { Trust } \\
\text { Science }\end{array}$ & $\begin{array}{c}\text { Trust } \\
\text { EU }\end{array}$ \\
\hline Health & & & & & & & & \\
& $-0.116^{* * *}$ & -0.0304 & $-0.129^{* * *}$ & 0.0185 & $0.0896^{* * *}$ & $-0.0753^{* *}$ & 0.0375 & $-0.110^{* * *}$ \\
& $(0.0284)$ & $(0.0282)$ & $(0.0330)$ & $(0.0298)$ & $(0.0328)$ & $(0.0298)$ & $(0.0314)$ & $(0.0281)$ \\
Observations & & & & & & & & \\
R-squared & 0.571 & 4,571 & 4,571 & 4,571 & 4,571 & 4,571 & 4,571 & 4,571 \\
\hline
\end{tabular}

The table presents estimates from OLS models. The outcome variables are stated in the first row. The sample compares the Health condition to the Baseline group. Controls include gender, age groups, employment status, education, immigrant status, fealth position of the enhance readability. Robust standard errors clustered at the province level are in parentheses. ${ }^{*} p<0.1 ; * * p<0.05 ; * * * p<0.01$

Table B6: Effects of Health vs the Baseline: Taxation outcomes

\begin{tabular}{|c|c|c|c|c|c|c|c|c|c|}
\hline & $\begin{array}{l}\text { Regulate } \\
\text { Markets }\end{array}$ & $\begin{array}{l}\text { +Taxes } \\
\text {-Poverty }\end{array}$ & $\begin{array}{c}\text { +Taxes } \\
+ \text { Health Exp. }\end{array}$ & $\begin{array}{c}\text { +Taxes } \\
\text { +Unemp. Welf. }\end{array}$ & $\begin{array}{c}\text { Taxes } \\
+ \text { Pensions }\end{array}$ & $\begin{array}{l}\text { Too Many } \\
\text { Immigrants }\end{array}$ & $\begin{array}{c}\text { Health Exp. } \\
\text { to Natives }\end{array}$ & $\begin{array}{c}\text { General Tax } \\
\text { too High }\end{array}$ & $\begin{array}{l}\text { Self Tax } \\
\text { too High }\end{array}$ \\
\hline Health & $\begin{array}{c}-0.0213 \\
(0.0312)\end{array}$ & $\begin{array}{c}-0.0834^{* * *} \\
(0.0283)\end{array}$ & $\begin{array}{l}-0.0536 \\
(0.0335)\end{array}$ & $\begin{array}{c}-0.0583^{* *} \\
(0.0289)\end{array}$ & $\begin{array}{c}-0.0839^{* * *} \\
(0.0295)\end{array}$ & $\begin{array}{l}-0.0151 \\
(0.0309)\end{array}$ & $\begin{array}{c}-0.0668^{* *} \\
(0.0289)\end{array}$ & $\begin{array}{l}0.00415 \\
(0.0238)\end{array}$ & $\begin{array}{c}0.0153 \\
(0.0291)\end{array}$ \\
\hline Observations & 4,571 & 4,571 & 4,571 & 4,571 & 4,571 & 4,571 & 4,571 & 4,571 & 4,571 \\
\hline R-squared & 0.073 & 0.016 & 0.052 & 0.055 & 0.046 & 0.027 & 0.019 & 0.125 & 0.106 \\
\hline
\end{tabular}

The table presents estimates from OLS models. The outcome variables are stated in the first row. The sample compares the Health condition to the Baseline group. Controls include gender, age groups, employment status, education, immigrant status, family status and mo (1) all controls are omitted to enhance readability. Robust standard errors clustered at the province level are in parentheses. $* p<0.1 ; * * p<0.05 ; * * * p<0.01$

Table B7: Effects of Health vs the Baseline: Voting outcomes

\begin{tabular}{|c|c|c|c|c|c|c|c|c|c|c|c|c|}
\hline & $\begin{array}{l}\text { Incumbent } \\
\text { Voting }\end{array}$ & $\begin{array}{c}\text { Populism } \\
\text { Voting }\end{array}$ & $\begin{array}{c}\text { Euroscept. } \\
\text { Voting }\end{array}$ & $\begin{array}{c}\text { Ideology } \\
\text { Left/right }\end{array}$ & $\begin{array}{c}\mathrm{EU} \\
\text { benefit }\end{array}$ & $\begin{array}{c}\text { EU } \\
\text { efficacy }\end{array}$ & $\begin{array}{c}\text { Leave } \\
\mathrm{EU}\end{array}$ & $\begin{array}{l}\text { Strong } \\
\text { Leader }\end{array}$ & $\begin{array}{c}\text { More } \\
\text { Privacy }\end{array}$ & $\begin{array}{l}\text { People } \\
\text { Power }\end{array}$ & $\begin{array}{c}\text { Free } \\
\text { Media }\end{array}$ & Plutocra. \\
\hline Health & $\begin{array}{c}0.0631^{* *} \\
(0.0287)\end{array}$ & $\begin{array}{c}0.00903 \\
(0.0298)\end{array}$ & $\begin{array}{c}0.0193 \\
(0.0312)\end{array}$ & $\begin{array}{l}0.0504^{*} \\
(0.0297)\end{array}$ & $\begin{array}{c}-0.0595^{* *} \\
(0.0290)\end{array}$ & $\begin{array}{c}-0.0969^{* * *} \\
(0.0296)\end{array}$ & $\begin{array}{r}-0.00613 \\
(0.0304)\end{array}$ & $\begin{array}{l}-0.0206 \\
(0.0326)\end{array}$ & $\begin{array}{l}-0.0484 \\
(0.0313)\end{array}$ & $\begin{array}{l}-0.0590 \\
(0.0386)\end{array}$ & $\begin{array}{l}-0.0190 \\
(0.0304)\end{array}$ & $\begin{array}{c}-0.0277 \\
(0.0307)\end{array}$ \\
\hline Observations & 4,571 & 4,571 & 4,571 & 4,571 & 4,571 & 4,571 & 4,571 & 4,571 & 4,571 & 4,571 & 4,571 & 4,571 \\
\hline $\mathrm{R}$-squared & 0.016 & 0.084 & 0.064 & 0.053 & 0.071 & 0.060 & 0.044 & 0.027 & 0.038 & 0.041 & 0.078 & 0.045 \\
\hline
\end{tabular}

The table presents estimates from OLS models. The outcome variables are stated in the first row. The sample compares the Health condition to the Baseline group. Controls include gender, age groups, employment status, education, immigrant status, family status and number of family members, equivalised household income (coded into five quantiles), a dummy to define the position of the Macron Speech question (see Section 3.1 for more details) and country fixed effects. All controls are omitted to position of the Macron Speech question (see Section 3.1 for more details) and country fixed effects. All controls are omitted to
enhance readability. Robust standard errors clustered at the province level are in parentheses. $* p<0.1 ; * * p<0.05 ; * * *<0.01$ 
Table B8: Effects of Health vs the Baseline: Identity outcomes

\begin{tabular}{|c|c|c|c|c|c|c|c|c|c|}
\hline & $\begin{array}{l}\text { Belong } \\
\text { Town }\end{array}$ & $\begin{array}{l}\text { Belong } \\
\text { Nation }\end{array}$ & $\begin{array}{c}\text { Belong } \\
\text { EU }\end{array}$ & $\begin{array}{l}\text { - Own Freedom } \\
+ \text { Public Safety }\end{array}$ & $\begin{array}{c}\text { - Own Freedom } \\
+ \text { Own Safety }\end{array}$ & $\begin{array}{l}\text { - Own Freedom } \\
+ \text { Family Safety }\end{array}$ & $\begin{array}{c}\text { Global Human } \\
\text { Rights }\end{array}$ & $\begin{array}{c}\text { Respect } \\
\text { Traditions }\end{array}$ & $\begin{array}{c}\text { Less } \\
\text { Globalization } \\
\end{array}$ \\
\hline Health & $\begin{array}{l}-0.0334 \\
(0.0282)\end{array}$ & $\begin{array}{c}0.0237 \\
(0.0296)\end{array}$ & $\begin{array}{c}-0.0614^{* *} \\
(0.0289)\end{array}$ & $\begin{array}{c}0.0125 \\
(0.0303)\end{array}$ & $\begin{array}{c}0.0155 \\
(0.0297)\end{array}$ & $\begin{array}{l}-0.00508 \\
(0.0291)\end{array}$ & $\begin{array}{l}0.00198 \\
(0.0312)\end{array}$ & $\begin{array}{l}-0.0102 \\
(0.0302)\end{array}$ & $\begin{array}{l}-0.00638 \\
(0.0288)\end{array}$ \\
\hline Observations & 4,571 & 4,571 & 4,571 & 4,571 & 4,571 & 4,571 & 4,571 & 4,571 & 4,571 \\
\hline R-squared & 0.030 & 0.029 & 0.037 & 0.011 & 0.017 & 0.027 & 0.031 & 0.052 & 0.049 \\
\hline
\end{tabular}

The table presents estimates from OLS models. The outcome variables are stated in the first row. The sample compares the Health condition to the Baseline group. Controls include gender, age groups, employment status, education, immigrant status, family status and number of family members, equivalised household income (coded into five quantiles), a dummy to define the ry fixed effects. All controls are omitted to

\section{B.2.2 Economic vs Health}

Table B9: Effects of Economic vs Health: Trust outcomes

\begin{tabular}{lcccccccc}
\hline & $\begin{array}{c}\text { Macron } \\
\text { Speech }\end{array}$ & $\begin{array}{c}\text { Trust } \\
\text { Politicians }\end{array}$ & $\begin{array}{c}\text { Social } \\
\text { Trust }\end{array}$ & $\begin{array}{c}\text { Trust } \\
\text { Government }\end{array}$ & $\begin{array}{c}\text { Trust } \\
\text { Police }\end{array}$ & $\begin{array}{c}\text { Trust } \\
\text { Media }\end{array}$ & $\begin{array}{c}\text { Trust } \\
\text { Science }\end{array}$ & $\begin{array}{c}\text { Trust } \\
\text { EU }\end{array}$ \\
\hline Economic & $-0.174^{* * *}$ & $-0.0905^{* * *}$ & $-0.186^{* * *}$ & -0.0438 & 0.0415 & $-0.134^{* * *}$ & 0.00536 & $-0.181^{* * *}$ \\
& $(0.0293)$ & $(0.0273)$ & $(0.0336)$ & $(0.0289)$ & $(0.0338)$ & $(0.0273)$ & $(0.0282)$ & $(0.0293)$ \\
& & & & & & & & \\
Observations & 3,665 & 3,665 & 3,665 & 3,665 & 3,665 & 3,665 & 3,665 & 3,665 \\
R-squared & 0.063 & 0.184 & 0.064 & 0.120 & 0.034 & 0.145 & 0.052 & 0.029 \\
\hline
\end{tabular}

The table presents estimates from OLS models. The outcome variables are stated in the first row. The sample compares the Economic condition to the Health group. Controls include gender, age groups, employment status, education, immigrant status, family status and number of family members, equivalised household income (coded into five quantiles), a dummy to define the position of the Macron Speech question (see Section 3.1 for more details) and country fixed effects. All controls are omitted to
enhance readability. Robust standard errors clustered at the province level are in parentheses. ${ }^{*} p<0.1 ; * * p<0.05 ; * * * p<0.01$

Table B10: Effects of Economic vs Health: Taxation outcomes

\begin{tabular}{|c|c|c|c|c|c|c|c|c|c|}
\hline & $\begin{array}{l}\text { Regulate } \\
\text { Markets }\end{array}$ & $\begin{array}{l}\text { +Taxes } \\
\text {-Poverty }\end{array}$ & $\begin{array}{c}\text { +Taxes } \\
+ \text { Health Exp. }\end{array}$ & $\begin{array}{c}\text { +Taxes } \\
\text { +Unemp. Welf. }\end{array}$ & $\begin{array}{c}\text { + Taxes } \\
+ \text { Pensions }\end{array}$ & $\begin{array}{c}\text { Too Many } \\
\text { Immigrants }\end{array}$ & $\begin{array}{c}\text { Health Exp. } \\
\text { to Natives }\end{array}$ & $\begin{array}{c}\text { General Tax } \\
\text { too High }\end{array}$ & $\begin{array}{l}\text { Self Tax } \\
\text { too High }\end{array}$ \\
\hline Economic & $\begin{array}{c}-0.0556^{*} \\
(0.0298)\end{array}$ & $\begin{array}{c}-0.106^{* * *} \\
(0.0308)\end{array}$ & $\begin{array}{c}-0.110^{* * *} \\
(0.0291)\end{array}$ & $\begin{array}{c}-0.0716^{* *} \\
(0.0281)\end{array}$ & $\begin{array}{c}-0.0685^{* *} \\
(0.0277)\end{array}$ & $\begin{array}{l}-0.0246 \\
(0.0316)\end{array}$ & $\begin{array}{c}-0.0615^{* *} \\
(0.0284)\end{array}$ & $\begin{array}{c}0.0706^{* *} \\
(0.0298)\end{array}$ & $\begin{array}{c}0.0911^{* *} \\
(0.0374)\end{array}$ \\
\hline Observations & 3,665 & 3,665 & 3,665 & 3,665 & 3,665 & 3,665 & 3,665 & 3,665 & 3,665 \\
\hline R-squared & 0.073 & 0.016 & 0.052 & 0.055 & 0.046 & 0.027 & 0.019 & 0.125 & 0.106 \\
\hline
\end{tabular}

The table presents estimates from OLS models. The outcome variables are stated in the first row. The sample compares the Economic condition to the Health group. Controls include gender, age groups, employment status, education, immigrant status, family status and a dummy to define the (sec Section 3.1 for position of the Macron Speech question (see Section 3.1 for more details) and country fixed effects. All controls are omitted to
enhance readability. Robust standard errors clustered at the province level are in parentheses. ${ }^{*} p<0.1 ; * * p<0.05 ; * * * p<0.01$ 
Table B11: Effects of Economic vs Health: Voting outcomes

\begin{tabular}{|c|c|c|c|c|c|c|c|c|c|c|c|c|}
\hline & $\begin{array}{c}\text { Incumbent } \\
\text { Voting }\end{array}$ & $\begin{array}{c}\text { Populism } \\
\text { Voting }\end{array}$ & $\begin{array}{c}\text { Euroscept. } \\
\text { Voting }\end{array}$ & $\begin{array}{c}\text { Ideology } \\
\text { Left/right }\end{array}$ & $\begin{array}{c}\text { EU } \\
\text { benefit }\end{array}$ & $\begin{array}{c}\text { EU } \\
\text { efficacy }\end{array}$ & $\begin{array}{c}\text { Leave } \\
\text { EU }\end{array}$ & $\begin{array}{l}\text { Strong } \\
\text { Leader }\end{array}$ & $\begin{array}{c}\text { More } \\
\text { Privacy }\end{array}$ & $\begin{array}{l}\text { People } \\
\text { Power }\end{array}$ & $\begin{array}{c}\text { Free } \\
\text { Media }\end{array}$ & Plutocra. \\
\hline Economic & $\begin{array}{l}-0.0210 \\
(0.0300)\end{array}$ & $\begin{array}{l}-0.0449 \\
(0.0287)\end{array}$ & $\begin{array}{c}-0.0354 \\
(0.0286)\end{array}$ & $\begin{array}{c}0.0449 \\
(0.0361)\end{array}$ & $\begin{array}{c}-0.176^{* * * *} \\
(0.0332)\end{array}$ & $\begin{array}{c}-0.166^{* * *} \\
(0.0343)\end{array}$ & $\begin{array}{c}0.0862^{* * *} \\
(0.0287)\end{array}$ & $\begin{array}{c}-0.0838^{* *} \\
(0.0355)\end{array}$ & $\begin{array}{c}-0.0740^{* *} \\
(0.0309)\end{array}$ & $\begin{array}{c}-0.0255 \\
(0.0283)\end{array}$ & $\begin{array}{c}0.0311 \\
(0.0297)\end{array}$ & $\begin{array}{c}0.0154 \\
(0.0294)\end{array}$ \\
\hline Observations & 3,665 & 3,665 & 3,665 & 3,665 & 3,665 & 3,665 & 3,665 & 3,665 & 3,665 & 3,665 & 3,665 & 3,665 \\
\hline R-squared & 0.016 & 0.084 & 0.064 & 0.053 & 0.071 & 0.060 & 0.044 & 0.027 & 0.038 & 0.041 & 0.078 & 0.045 \\
\hline
\end{tabular}

The table presents estimates from OLS models. The outcome variables are stated in the first row. The sample compares the Economic condition to the Health group. Controls include gender, age groups, employment status, education, immigrant status, family status and number of family members, equivalised household income (coded into five quantiles), a dummy to define the position of the Macron Speech question (see Section 3.1 for more details) and country fixed effects. All controls are omitted to enhance readability. Robust standard errors clustered at the province level are in parentheses. ${ }^{*} p<0.1 ;{ }^{* *} p<0.05 ; * * * p<0.01$

Table B12: Effects of Economic vs Health: Identity outcomes

\begin{tabular}{|c|c|c|c|c|c|c|c|c|c|}
\hline & $\begin{array}{c}\text { Belong } \\
\text { Town }\end{array}$ & $\begin{array}{l}\text { Belong } \\
\text { Nation }\end{array}$ & $\begin{array}{c}\text { Belong } \\
\text { EU }\end{array}$ & $\begin{array}{l}\text { - Own Freedom } \\
\text { + Public Safety }\end{array}$ & $\begin{array}{l}\text { - Own Freedom } \\
\text { + Own Safety }\end{array}$ & $\begin{array}{l}\text { - Own Freedom } \\
+ \text { Family Safety }\end{array}$ & $\begin{array}{l}\text { Global Human } \\
\text { Rights }\end{array}$ & $\begin{array}{c}\text { Respect } \\
\text { Traditions }\end{array}$ & $\begin{array}{c}\text { Less } \\
\text { Globalization }\end{array}$ \\
\hline Economic & $\begin{array}{l}-0.0216 \\
(0.0332)\end{array}$ & $\begin{array}{l}-0.00615 \\
(0.0317)\end{array}$ & $\begin{array}{c}-0.122^{* * *} \\
(0.0279)\end{array}$ & $\begin{array}{c}-0.0689^{* *} \\
(0.0300)\end{array}$ & $\begin{array}{l}-0.0532^{*} \\
(0.0281)\end{array}$ & $\begin{array}{c}-0.0706^{* *} \\
(0.0295)\end{array}$ & $\begin{array}{l}-0.0116 \\
(0.0290)\end{array}$ & $\begin{array}{l}0.00920 \\
(0.0312)\end{array}$ & $\begin{array}{l}0.00623 \\
(0.0287)\end{array}$ \\
\hline Observations & 3,665 & 3,665 & 3,665 & 3,665 & 3,665 & 3,665 & 3,665 & 3,665 & 3,665 \\
\hline R-squared & 0.030 & 0.029 & 0.037 & 0.011 & 0.017 & 0.027 & 0.031 & 0.052 & 0.049 \\
\hline
\end{tabular}

The table presents estimates from OLS models. The outcome variables are stated in the first row. The sample compares the Economic condition to the Health group. Controls include gender, age groups, employment status, education, immigrant status, family status and number of family members, equivalised household income (coded into five quantiles), a dummy to define the position of the Macron Speech question (see Section 3.1 for more details) and country fixed effects. All controls are omitted to enhance readability. Robust standard errors clustered at the province level are in parentheses. ${ }^{*} p<0.1 ; * * p<0.05 ; * * * p<0.01$

\section{B.2.3 Conflict vs Health}

Table B13: Effects of Conflict vs Health: Trust outcomes

\begin{tabular}{|c|c|c|c|c|c|c|c|c|}
\hline & $\begin{array}{l}\text { Macron } \\
\text { Speech }\end{array}$ & $\begin{array}{c}\text { Trust } \\
\text { Politicians }\end{array}$ & $\begin{array}{l}\text { Social } \\
\text { Trust }\end{array}$ & $\begin{array}{c}\text { Trust } \\
\text { Government }\end{array}$ & $\begin{array}{l}\text { Trust } \\
\text { Police }\end{array}$ & $\begin{array}{l}\text { Trust } \\
\text { Media }\end{array}$ & $\begin{array}{c}\text { Trust } \\
\text { Science }\end{array}$ & $\begin{array}{c}\text { Trust } \\
\text { EU }\end{array}$ \\
\hline Conflict & $\begin{array}{c}-0.139^{* * *} \\
(0.0296)\end{array}$ & $\begin{array}{l}0.00445 \\
(0.0258)\end{array}$ & $\begin{array}{c}-0.0697^{* *} \\
(0.0317)\end{array}$ & $\begin{array}{c}0.0386 \\
(0.0273)\end{array}$ & $\begin{array}{c}0.114^{* * *} \\
(0.0316)\end{array}$ & $\begin{array}{l}-0.0426 \\
(0.0280)\end{array}$ & $\begin{array}{c}0.223^{* * *} \\
(0.0387)\end{array}$ & $\begin{array}{c}-0.0682^{* *} \\
(0.0298)\end{array}$ \\
\hline Observations & 3,663 & 3,663 & 3,663 & 3,663 & 3,663 & 3,663 & 3,663 & 3,663 \\
\hline R-squared & 0.063 & 0.184 & 0.064 & 0.120 & 0.034 & 0.145 & 0.052 & 0.029 \\
\hline
\end{tabular}

The table presents estimates from OLS models. The outcome variables are stated in the first row. The sample compares the Conflict condition to the Health group. Controls include gender, age groups, employment status, education, immigrant status, family status and number of family members, equivalised household income (coded into five quantiles), a dummy to define the position of the Macron Speech question (see Section 3.1 for more details) and country fixed effects. All controls are omitted to enhance readability. Robust standard errors clustered at the province level are in parentheses. ${ }^{*} p<0.1 ;{ }^{* *} p<0.05$; ${ }^{* * *} p<0.01$ 
Table B14: Effects of Conflict vs Health: Taxation outcomes

\begin{tabular}{|c|c|c|c|c|c|c|c|c|c|}
\hline & $\begin{array}{l}\text { Regulate } \\
\text { Markets }\end{array}$ & $\begin{array}{l}\text { +Taxes } \\
\text {-Poverty }\end{array}$ & $\begin{array}{c}\text { + Taxes } \\
+ \text { Health Exp. }\end{array}$ & $\begin{array}{c}\text { + Taxes } \\
\text { +Unemp. Welf. }\end{array}$ & $\begin{array}{l}\text { + Taxes } \\
+ \text { Pensions }\end{array}$ & $\begin{array}{l}\text { Too Many } \\
\text { Immigrants }\end{array}$ & $\begin{array}{l}\text { Health Exp. } \\
\text { to Natives }\end{array}$ & $\begin{array}{c}\text { General Tax } \\
\text { too High }\end{array}$ & $\begin{array}{l}\text { Self Tax } \\
\text { too High }\end{array}$ \\
\hline Conflict & $\begin{array}{c}-0.00380 \\
(0.0267)\end{array}$ & $\begin{array}{c}-0.103^{* * *} \\
(0.0299)\end{array}$ & $\begin{array}{c}-0.0478 \\
(0.0310)\end{array}$ & $\begin{array}{c}-0.0436 \\
(0.0293)\end{array}$ & $\begin{array}{c}-0.0597^{* *} \\
(0.0295)\end{array}$ & $\begin{array}{r}-0.00167 \\
(0.0320)\end{array}$ & $\begin{array}{c}-0.0676^{* *} \\
(0.0304)\end{array}$ & $\begin{array}{c}0.0144 \\
(0.0258)\end{array}$ & $\begin{array}{c}0.0679^{* *} \\
(0.0284)\end{array}$ \\
\hline Observations & 3,663 & 3,663 & 3,663 & 3,663 & 3,663 & 3,663 & 3,663 & 3,663 & 3,663 \\
\hline R-squared & 0.073 & 0.016 & 0.052 & 0.055 & 0.046 & 0.027 & 0.019 & 0.125 & 0.106 \\
\hline
\end{tabular}

The table presents estimates from OLS models. The outcome variables are stated in the first row. The sample compares the Conflict condition to the Health group. Controls include gender, age groups, employment status, education, immigrant status, family status and number of family members, equivalised household income (coded into five quantiles), a dummy to define the position of the Macron Speech question (see Section 3.1 for more details) and country fixed effects. All controls are omitted to enhance readability. Robust standard errors clustered at the province level are in parentheses. ${ }^{*} p<0.1 ; * * p<0.05 ; * * * p<0.01$

Table B15: Effects of Conflict vs Health: Voting outcomes

\begin{tabular}{|c|c|c|c|c|c|c|c|c|c|c|c|c|}
\hline & $\begin{array}{c}\text { Incumbent } \\
\text { Voting }\end{array}$ & $\begin{array}{c}\text { Populism } \\
\text { Voting }\end{array}$ & $\begin{array}{c}\text { Euroscept. } \\
\text { Voting }\end{array}$ & $\begin{array}{c}\text { Ideology } \\
\text { Left/right }\end{array}$ & $\begin{array}{c}\text { EU } \\
\text { benefit }\end{array}$ & $\begin{array}{c}\text { EU } \\
\text { efficacy }\end{array}$ & $\begin{array}{l}\text { Leave } \\
\text { EU }\end{array}$ & $\begin{array}{l}\text { Strong } \\
\text { Leader }\end{array}$ & $\begin{array}{c}\text { More } \\
\text { Privacy }\end{array}$ & $\begin{array}{l}\text { People } \\
\text { Power }\end{array}$ & $\begin{array}{l}\text { Free } \\
\text { Media }\end{array}$ & Plutocra. \\
\hline Conflict & $\begin{array}{c}0.0130 \\
(0.0271)\end{array}$ & $\begin{array}{l}-0.0103 \\
(0.0255)\end{array}$ & $\begin{array}{l}-0.00855 \\
(0.0246)\end{array}$ & $\begin{array}{l}0.00639 \\
(0.0268)\end{array}$ & $\begin{array}{c}-0.0745^{* * *} \\
(0.0281)\end{array}$ & $\begin{array}{l}-0.0320 \\
(0.0283)\end{array}$ & $\begin{array}{c}-0.0401 \\
(0.0299)\end{array}$ & $\begin{array}{c}-0.0589^{* *} \\
(0.0298)\end{array}$ & $\begin{array}{l}0.00962 \\
(0.0314)\end{array}$ & $\begin{array}{c}-0.0700^{* *} \\
(0.0304)\end{array}$ & $\begin{array}{l}-0.0133 \\
(0.0328)\end{array}$ & $\begin{array}{c}0.0106 \\
(0.0285)\end{array}$ \\
\hline Observations & 3,663 & 3,663 & 3,663 & 3,663 & 3,663 & 3,663 & 3,663 & 3,663 & 3,663 & 3,663 & 3,663 & 3,663 \\
\hline $\mathrm{R}$-squared & 0.016 & 0.084 & 0.064 & 0.053 & 0.071 & 0.060 & 0.044 & 0.027 & 0.038 & 0.041 & 0.078 & 0.045 \\
\hline
\end{tabular}

The table presents estimates from OLS models. The outcome variables are stated in the first row. The sample compares the Conflict condition to the Health group. Controls include gender, age groups, employment status, education, immigrant status, family status and number of family members, equivalised household income (coded into five quantiles), a dummy to define the position of the Macron Speech question (see Section 3.1 for more details) and country fixed effects. All controls are omitted to enhance readability. Robust standard errors clustered at the province level are in parentheses. ${ }^{*} p<0.1 ; * * p<0.05 ; * * * p<0.01$

Table B16: Effects of Conflict vs Health: Identity outcomes

\begin{tabular}{|c|c|c|c|c|c|c|c|c|c|}
\hline & $\begin{array}{c}\text { Belong } \\
\text { Town }\end{array}$ & $\begin{array}{l}\text { Belong } \\
\text { Nation } \\
\end{array}$ & $\begin{array}{l}\text { Belong } \\
\text { EU }\end{array}$ & $\begin{array}{l}\text { - Own Freedom } \\
+ \text { Public Safety }\end{array}$ & $\begin{array}{l}\text { - Own Freedom } \\
+ \text { Own Safety }\end{array}$ & $\begin{array}{l}\text { - Own Freedom } \\
+ \text { Family Safety }\end{array}$ & $\begin{array}{c}\text { Global Human } \\
\text { Rights }\end{array}$ & $\begin{array}{c}\text { Respect } \\
\text { Traditions }\end{array}$ & $\begin{array}{c}\text { Less } \\
\text { Globalization } \\
\end{array}$ \\
\hline Conflict & $\begin{array}{l}0.00957 \\
(0.0308)\end{array}$ & $\begin{array}{c}0.0616^{* *} \\
(0.0260)\end{array}$ & $\begin{array}{l}-0.0454 \\
(0.0288)\end{array}$ & $\begin{array}{l}0.00197 \\
(0.0292)\end{array}$ & $\begin{array}{c}0.0167 \\
(0.0314)\end{array}$ & $\begin{array}{c}0.0127 \\
(0.0294)\end{array}$ & $\begin{array}{c}0.0237 \\
(0.0270)\end{array}$ & $\begin{array}{c}0.0323 \\
(0.0290)\end{array}$ & $\begin{array}{l}-0.00851 \\
(0.0300)\end{array}$ \\
\hline Observations & 3,663 & 3,663 & 3,663 & 3,663 & 3,663 & 3,663 & 3,663 & 3,663 & 3,663 \\
\hline R-squared & 0.030 & 0.029 & 0.037 & 0.011 & 0.017 & 0.027 & 0.031 & 0.052 & 0.049 \\
\hline
\end{tabular}

The table presents estimates from OLS models. The outcome variables are stated in the first row. The sample compares the Conflict condition to the Health group. Controls include gender, age groups, employment status, education, immigrant status, family status and number of family members, equivalised household income (coded into five quantiles), a dummy to define the position of the Macron Speech question (see Section 3.1 for more details) and country fixed effects. All controls are omitted to
enhance readability. Robust standard errors clustered at the province level are in parentheses. ${ }^{*} p<0.1 ; *^{*} p<0.05 ; * * *<0.01$ 


\section{B.3 Country analyses}

\section{B.3.1 Germany}

Table B17: Effects of Covidfirst vs Baseline - Germany: Trust outcomes

\begin{tabular}{lcccccccc}
\hline & $\begin{array}{c}\text { Macron } \\
\text { Speech }\end{array}$ & $\begin{array}{c}\text { Trust } \\
\text { Politicians }\end{array}$ & $\begin{array}{c}\text { Social } \\
\text { Trust }\end{array}$ & $\begin{array}{c}\text { Trust } \\
\text { Government }\end{array}$ & $\begin{array}{c}\text { Trust } \\
\text { Police }\end{array}$ & $\begin{array}{c}\text { Trust } \\
\text { Media }\end{array}$ & $\begin{array}{c}\text { Trust } \\
\text { Science }\end{array}$ & $\begin{array}{c}\text { Trust } \\
\text { EU }\end{array}$ \\
\hline Covidfirst & $-0.166^{* * *}$ & -0.0399 & -0.0278 & -0.0258 & 0.0482 & -0.0690 & $0.170^{* * *}$ & $-0.156^{* * *}$ \\
& $(0.0447)$ & $(0.0433)$ & $(0.0463)$ & $(0.0429)$ & $(0.0471)$ & $(0.0457)$ & $(0.0479)$ & $(0.0441)$ \\
& & & & & & & & \\
Observations & 2,161 & 2,161 & 2,161 & 2,161 & 2,161 & 2,161 & 2,161 & 2,161 \\
R-squared & 0.031 & 0.030 & 0.068 & 0.046 & 0.049 & 0.041 & 0.046 & 0.032 \\
\hline
\end{tabular}

The table presents estimates from OLS models. The outcome variables are stated in the first row. The sample solely includes observations from Germany and compares the COVIDFIRST condition to the Baseline condition. Controls include gender, age groups, employment status, education, immigrant status, family status and number of family members, equivalised household income (coded into five quantiles) and a dummy to define the position of the Macron Speech question (see Section 3.1 for more details). All controls are omitted to enhance readability. Robust standard errors clustered at the province level are in parenthese

details). All controls are omitted to enhance readability. Robust standard errors clustered at the province level are in parentheses.

Table B18: Effects of Covidfirst vs Baseline - Germany: Taxation outcomes

\begin{tabular}{|c|c|c|c|c|c|c|c|c|c|}
\hline & $\begin{array}{l}\text { Regulate } \\
\text { Markets }\end{array}$ & $\begin{array}{l}\text { + Taxes } \\
\text {-Poverty }\end{array}$ & $\begin{array}{c}\text { + Taxes } \\
+ \text { Health Exp. }\end{array}$ & $\begin{array}{c}\text { + Taxes } \\
\text { +Unemp. Welf. }\end{array}$ & $\begin{array}{l}\text { + Taxes } \\
+ \text { Pensions }\end{array}$ & $\begin{array}{l}\text { Too Many } \\
\text { Immigrants }\end{array}$ & $\begin{array}{c}\text { Health Exp. } \\
\text { to Natives }\end{array}$ & $\begin{array}{c}\text { General Tax } \\
\text { too High }\end{array}$ & $\begin{array}{l}\text { Self Tax } \\
\text { too High }\end{array}$ \\
\hline Covidfirst & $\begin{array}{c}-0.0913^{*} \\
(0.0481)\end{array}$ & $\begin{array}{c}-0.0823^{*} \\
(0.0439)\end{array}$ & $\begin{array}{l}-0.0669 \\
(0.0507)\end{array}$ & $\begin{array}{l}-0.0582 \\
(0.0494)\end{array}$ & $\begin{array}{l}-0.0725 \\
(0.0481)\end{array}$ & $\begin{array}{l}-0.0302 \\
(0.0453)\end{array}$ & $\begin{array}{l}-0.0424 \\
(0.0426)\end{array}$ & $\begin{array}{l}-0.0305 \\
(0.0491)\end{array}$ & $\begin{array}{c}0.0392 \\
(0.0485)\end{array}$ \\
\hline Observations & 2,161 & 2,161 & 2,161 & 2,161 & 2,161 & 2,161 & 2,161 & 2,161 & 2,161 \\
\hline R-squared & 0.007 & 0.021 & 0.010 & 0.023 & 0.009 & 0.034 & 0.028 & 0.020 & 0.015 \\
\hline
\end{tabular}

The table presents estimates from OLS models. The outcome variables are stated in the first row. The sample solely includes observations from Germany and compares the COVIDFIRST condition to the Baseline condition. Controls include gender, age ( $* p<0.1 ; * * p<0.05 ; * * * p<0.01$

Table B19: Effects of Covidfirst vs Baseline - Germany: Voting outcomes

\begin{tabular}{|c|c|c|c|c|c|c|c|c|c|c|c|c|}
\hline & $\begin{array}{l}\text { Incumbent } \\
\text { Voting }\end{array}$ & $\begin{array}{c}\text { Populism } \\
\text { Voting }\end{array}$ & $\begin{array}{c}\text { Euroscept. } \\
\text { Voting }\end{array}$ & $\begin{array}{c}\text { Ideology } \\
\text { Left/right }\end{array}$ & $\begin{array}{c}\mathrm{EU} \\
\text { benefit }\end{array}$ & $\begin{array}{c}\text { EU } \\
\text { efficacy }\end{array}$ & $\begin{array}{c}\text { Leave } \\
\text { EU }\end{array}$ & $\begin{array}{l}\text { Strong } \\
\text { Leader }\end{array}$ & $\begin{array}{c}\text { More } \\
\text { Privacy }\end{array}$ & $\begin{array}{l}\text { People } \\
\text { Power }\end{array}$ & $\begin{array}{c}\text { Free } \\
\text { Media } \\
\end{array}$ & Plutocra. \\
\hline Covidfirst & $\begin{array}{c}-0.00493 \\
(0.0463)\end{array}$ & $\begin{array}{l}0.00578 \\
(0.0347)\end{array}$ & $\begin{array}{l}0.00584 \\
(0.0351)\end{array}$ & $\begin{array}{c}0.0248 \\
(0.0326)\end{array}$ & $\begin{array}{c}-0.125^{* * *} \\
(0.0415)\end{array}$ & $\begin{array}{c}-0.180^{* * *} \\
(0.0403)\end{array}$ & $\begin{array}{c}0.0626 \\
(0.0426)\end{array}$ & $\begin{array}{c}-0.0957^{* *} \\
(0.0400)\end{array}$ & $\begin{array}{c}-0.0580 \\
(0.0480)\end{array}$ & $\begin{array}{c}-0.0757^{*} \\
(0.0426)\end{array}$ & $\begin{array}{c}-0.0393 \\
(0.0469)\end{array}$ & $\begin{array}{c}-0.0511 \\
(0.0450)\end{array}$ \\
\hline Observations & 2,161 & 2,161 & 2,161 & 2,161 & 2,161 & 2,161 & 2,161 & 2,161 & 2,161 & 2,161 & 2,161 & 2,161 \\
\hline R-squared & 0.026 & 0.009 & 0.009 & 0.017 & 0.055 & 0.027 & 0.020 & 0.018 & 0.025 & 0.033 & 0.030 & 0.019 \\
\hline
\end{tabular}

The table presents estimates from OLS models. The outcome variables are stated in the first row. The sample solely includes observations from Germany and compares the COVIDFIRST condition to the Baseline condition. Controls include gender, age

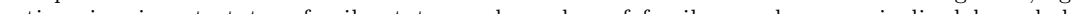
incon (c) All con into (s $p<0.1 ; * * p<0.05 ; * * * p<0.01$ 
Table B20: Effects of Covidfirst vs Baseline - Germany: Identity outcomes

\begin{tabular}{|c|c|c|c|c|c|c|c|c|c|}
\hline & $\begin{array}{l}\text { Belong } \\
\text { Town }\end{array}$ & $\begin{array}{l}\text { Belong } \\
\text { Nation }\end{array}$ & $\begin{array}{c}\text { Belong } \\
\text { EU }\end{array}$ & $\begin{array}{l}\text { - Own Freedom } \\
+ \text { Public Safety }\end{array}$ & $\begin{array}{c}\text { - Own Freedom } \\
+ \text { Own Safety }\end{array}$ & $\begin{array}{l}\text { - Own Freedom } \\
+ \text { Family Safety }\end{array}$ & $\begin{array}{l}\text { Global Human } \\
\text { Rights }\end{array}$ & $\begin{array}{c}\text { Respect } \\
\text { Traditions }\end{array}$ & $\begin{array}{c}\text { Less } \\
\text { Globalization }\end{array}$ \\
\hline Covidfirst & $\begin{array}{l}-0.0732 \\
(0.0503)\end{array}$ & $\begin{array}{c}-0.00480 \\
(0.0461)\end{array}$ & $\begin{array}{c}-0.157^{* * * *} \\
(0.0461)\end{array}$ & $\begin{array}{l}-0.0887^{*} \\
(0.0472)\end{array}$ & $\begin{array}{l}-0.0299 \\
(0.0472)\end{array}$ & $\begin{array}{l}-0.0778^{*} \\
(0.0443)\end{array}$ & $\begin{array}{l}-0.0558 \\
(0.0568)\end{array}$ & $\begin{array}{l}-0.0534 \\
(0.0517)\end{array}$ & $\begin{array}{c}-0.00949 \\
(0.0450)\end{array}$ \\
\hline Observations & 2,161 & 2,161 & 2,161 & 2.161 & 2,161 & 2,161 & 2,161 & 2,161 & 2.161 \\
\hline R-squared & 0.027 & 0.033 & 0.040 & 0.005 & 0.010 & 0.024 & 0.019 & 0.014 & 0.007 \\
\hline
\end{tabular}

The table presents estimates from OLS models. The outcome variables are stated in the first row. The sample solely includes observations from Germany and compares the COVIDFIRST condition to the Baseline condition. Controls include gender, age groups, employment status, education, immigrant status, family status and number of family members, equivalised household

details). All controls are omitted to enhance readability. Ro

\section{B.3.2 Italy}

Table B21: Effects of Covidfirst vs Baseline - Italy: Trust outcomes

\begin{tabular}{lcccccccc}
\hline & $\begin{array}{c}\text { Macron } \\
\text { Speech }\end{array}$ & $\begin{array}{c}\text { Trust } \\
\text { Politicians }\end{array}$ & $\begin{array}{c}\text { Social } \\
\text { Trust }\end{array}$ & $\begin{array}{c}\text { Trust } \\
\text { Government }\end{array}$ & $\begin{array}{c}\text { Trust } \\
\text { Police }\end{array}$ & $\begin{array}{c}\text { Trust } \\
\text { Media }\end{array}$ & $\begin{array}{c}\text { Trust } \\
\text { Science }\end{array}$ & $\begin{array}{c}\text { Trust } \\
\text { EU }\end{array}$ \\
\hline & & & & & & & & \\
Covidfirst & $-0.167^{* * *}$ & $-0.0834^{*}$ & $-0.110^{* *}$ & -0.00220 & $0.0781^{*}$ & $-0.124^{* * *}$ & 0.0213 & $-0.152^{* * *}$ \\
& $(0.0410)$ & $(0.0427)$ & $(0.0515)$ & $(0.0455)$ & $(0.0429)$ & $(0.0425)$ & $(0.0535)$ & $(0.0463)$ \\
& & & & & & & & \\
Observations & 2,003 & 2,003 & 2,003 & 2,003 & 2,003 & 2,003 & 2,003 & 2,003 \\
R-squared & 0.051 & 0.020 & 0.023 & 0.025 & 0.043 & 0.015 & 0.029 & 0.056 \\
\hline
\end{tabular}

The table presents estimates from OLS models. The outcome variables are stated in the first row. The sample solely includes observations from Italy and compares the COVIDFIRST condition to the Baseline condition. Controls include gender, age groups, employment status, education, immigrant status, family status and number of family members, equivalised household income (coded into five quantiles) and a dummy to define the position of the Macron Speech question (see Section 3.1 for more details). All controls are omitted to enhance readability. Robust standard errors clustered at the province level are in parentheses

$p<0.1 ; * * p<0.05 ; * * * \quad p<0.01$

Table B22: Effects of Covidfirst vs Baseline - Italy: Taxation outcomes

\begin{tabular}{|c|c|c|c|c|c|c|c|c|c|}
\hline & $\begin{array}{l}\text { Regulate } \\
\text { Markets }\end{array}$ & $\begin{array}{l}\text { +Taxes } \\
\text {-Poverty }\end{array}$ & $\begin{array}{c}\text { +Taxes } \\
+ \text { Health Exp. }\end{array}$ & $\begin{array}{c}\text { +Taxes } \\
\text { +Unemp. Welf. }\end{array}$ & $\begin{array}{c}+ \text { Taxes } \\
+ \text { Pensions } \\
\end{array}$ & $\begin{array}{c}\text { Too Many } \\
\text { Immigrants }\end{array}$ & $\begin{array}{c}\text { Health Exp. } \\
\text { to Natives }\end{array}$ & $\begin{array}{c}\text { General Tax } \\
\text { too High }\end{array}$ & $\begin{array}{l}\text { Self Tax } \\
\text { too High }\end{array}$ \\
\hline Covidfirst & $\begin{array}{l}-0.0209 \\
(0.0436)\end{array}$ & $\begin{array}{c}-0.121^{* *} \\
(0.0478)\end{array}$ & $\begin{array}{c}-0.128^{* * *} \\
(0.0432)\end{array}$ & $\begin{array}{c}-0.0730^{*} \\
(0.0415)\end{array}$ & $\begin{array}{c}-0.110^{* * *} \\
(0.0385)\end{array}$ & $\begin{array}{c}0.0275 \\
(0.0499)\end{array}$ & $\begin{array}{c}-0.0998^{*} \\
(0.0513)\end{array}$ & $\begin{array}{c}0.117^{* * *} \\
(0.0443)\end{array}$ & $\begin{array}{c}0.168^{* * *} \\
(0.0445)\end{array}$ \\
\hline Observations & 2,003 & 2,003 & 2,003 & 2,003 & 2,003 & 2,003 & 2,003 & 2,003 & 2,003 \\
\hline R-squared & 0.011 & 0.027 & 0.037 & 0.032 & 0.033 & 0.034 & 0.027 & 0.015 & 0.022 \\
\hline
\end{tabular}

The table presents estimates from OLS models. The outcome variables are stated in the first row. The sample solely includes observations from Italy and compares the COVIDFIRST condition to the Baseline condition. Controls include gender, age groups, employment status, education, immigrant status, family status and number of family members, equivalised household income (coded into five quantiles) and a dummy to define the position of the Macron Speech question (see Section 3.1 for more details). All controls are omitted to enhance readability. Robust standard errors clustered at the province level are in parentheses.

$* p<0.1 ; * * \quad p<0.05 ; * * * p<0.01$ 
Table B23: Effects of Covidfirst vs Baseline - Italy: Voting outcomes

\begin{tabular}{|c|c|c|c|c|c|c|c|c|c|c|c|c|}
\hline & $\begin{array}{l}\text { Incumbent } \\
\text { Voting }\end{array}$ & $\begin{array}{c}\text { Populism } \\
\text { Voting }\end{array}$ & $\begin{array}{c}\text { Euroscept. } \\
\text { Voting }\end{array}$ & $\begin{array}{c}\text { Ideology } \\
\text { Left/right }\end{array}$ & $\begin{array}{c}\text { EU } \\
\text { benefit }\end{array}$ & $\begin{array}{c}\text { EU } \\
\text { efficacy }\end{array}$ & $\begin{array}{c}\text { Leave } \\
\text { EU }\end{array}$ & $\begin{array}{l}\text { Strong } \\
\text { Leader }\end{array}$ & $\begin{array}{c}\text { More } \\
\text { Privacy }\end{array}$ & $\begin{array}{l}\text { People } \\
\text { Power }\end{array}$ & $\begin{array}{c}\text { Free } \\
\text { Media }\end{array}$ & Plutocra. \\
\hline Covidfirst & $\begin{array}{c}0.0331 \\
(0.0483)\end{array}$ & $\begin{array}{l}-0.0240 \\
(0.0581)\end{array}$ & $\begin{array}{l}0.00307 \\
(0.0574)\end{array}$ & $\begin{array}{c}0.0764 \\
(0.0508)\end{array}$ & $\begin{array}{c}-0.113^{* *} \\
(0.0476)\end{array}$ & $\begin{array}{c}-0.111^{* *} \\
(0.0440)\end{array}$ & $\begin{array}{c}0.0374 \\
(0.0516)\end{array}$ & $\begin{array}{l}0.00310 \\
(0.0643)\end{array}$ & $\begin{array}{l}-0.0547 \\
(0.0543)\end{array}$ & $\begin{array}{c}0.0417 \\
(0.0571)\end{array}$ & $\begin{array}{c}0.0177 \\
(0.0478)\end{array}$ & $\begin{array}{c}0.0339 \\
(0.0517)\end{array}$ \\
\hline Observations & 2,003 & 2,003 & 2,003 & 2,003 & 2,003 & 2,003 & 2,003 & 2,003 & 2,003 & 2,003 & 2,003 & 2,003 \\
\hline R-squared & 0.031 & 0.023 & 0.021 & 0.019 & 0.063 & 0.042 & 0.036 & 0.026 & 0.015 & 0.036 & 0.027 & 0.013 \\
\hline
\end{tabular}

The table presents estimates from OLS models. The outcome variables are stated in the first row. The sample solely includes observations from Italy and compares the COVIDFIRST condition to the Baseline condition. Controls include gender, age groups, employment status, education, immigrant status, family status and number of family members, equivalised household income (coded into five quantiles) and a dummy to define the position of the Macron Speech question (see Section 3.1 for more details). All controls are omitted to enhance readability. Robust standard errors clustered at the province level are in parentheses.

$* p<0.1 ; * * \quad p<0.05 ; * * * \quad p<0.01$

Table B24: Effects of Covidfirst vs Baseline - Italy: Identity outcomes

\begin{tabular}{lccccccccc}
\hline & $\begin{array}{c}\text { Belong } \\
\text { Town }\end{array}$ & $\begin{array}{c}\text { Belong } \\
\text { Nation }\end{array}$ & $\begin{array}{c}\text { Belong } \\
\mathrm{EU}\end{array}$ & $\begin{array}{c}\text { - Own Freedom } \\
\text { + Public Safety }\end{array}$ & $\begin{array}{c}\text { - Own Freedom } \\
\text { + Own Safety }\end{array}$ & $\begin{array}{c}\text { - Own Freedom } \\
\text { + Family Safety }\end{array}$ & $\begin{array}{c}\text { Global Human } \\
\text { Rights }\end{array}$ & $\begin{array}{c}\text { Respect } \\
\text { Traditions }\end{array}$ & $\begin{array}{c}\text { Less } \\
\text { Globalization }\end{array}$ \\
\hline Covidfirst & -0.0121 & 0.0306 & -0.0730 & 0.0230 & 0.0703 & $0.0814^{*}$ & 0.0309 & -0.00787 & 0.0613 \\
& $(0.0534)$ & $(0.0559)$ & $(0.0488)$ & $(0.0537)$ & $(0.0457)$ & $(0.0490)$ & $(0.0470)$ & $(0.0468)$ & $(0.0497)$ \\
& & & & & & & & & \\
Observations & 2,003 & 2,003 & 2,003 & 2,003 & 2,003 & 2,003 & 2,003 & 2,003 \\
R-squared & 0.026 & 0.031 & 0.056 & 0.013 & 0.012 & 0.030 & 2,003 & 0.014 & 0.048 \\
\hline
\end{tabular}

The table presents estimates from OLS models. The outcome variables are stated in the first row. The sample solely includes observations from Italy and compares the COVIDFIRST condition to the Baseline condition. Controls include gender, age groups, employment status, education, immigrant status, family status and number of family members, equivalised household income (coded into five quantiles) and a dummy to define the position of the Macron Speech question (see Section 3.1 for more details). All controls are omitted to enhance readability. Robust standard errors clustered at the province level are in parentheses.

$* p<0.1 ; * * p<0.05 ; * * * p<0.01$

\section{B.3.3 The Netherlands}

Table B25: Effects of Covidfirst vs Baseline - Netherlands: Trust outcomes

\begin{tabular}{|c|c|c|c|c|c|c|c|c|}
\hline & $\begin{array}{l}\text { Macron } \\
\text { Speech }\end{array}$ & $\begin{array}{c}\text { Trust } \\
\text { Politicians } \\
\end{array}$ & $\begin{array}{l}\text { Social } \\
\text { Trust }\end{array}$ & $\begin{array}{c}\text { Trust } \\
\text { Government }\end{array}$ & $\begin{array}{l}\text { Trust } \\
\text { Police }\end{array}$ & $\begin{array}{l}\text { Trust } \\
\text { Media }\end{array}$ & $\begin{array}{c}\text { Trust } \\
\text { Science }\end{array}$ & $\begin{array}{c}\text { Trust } \\
\text { EU }\end{array}$ \\
\hline Covidfirst & $\begin{array}{c}-0.205^{* * *} \\
(0.0354)\end{array}$ & $\begin{array}{l}-0.0319 \\
(0.0254)\end{array}$ & $\begin{array}{c}-0.153^{* *} \\
(0.0553)\end{array}$ & $\begin{array}{c}0.0197 \\
(0.0373)\end{array}$ & $\begin{array}{c}0.0403 \\
(0.0391)\end{array}$ & $\begin{array}{c}-0.0799^{* * *} \\
(0.0223)\end{array}$ & $\begin{array}{c}0.0147 \\
(0.0355)\end{array}$ & $\begin{array}{c}-0.108^{* *} \\
(0.0369)\end{array}$ \\
\hline Observations & 2,071 & 2,071 & 2,071 & 2,071 & 2,071 & 2,071 & 2,071 & 2,071 \\
\hline R-squared & 0.055 & 0.022 & 0.023 & 0.027 & 0.033 & 0.019 & 0.020 & 0.027 \\
\hline
\end{tabular}

The table presents estimates from OLS models. The outcome variables are stated in the first row. The sample solely includes observations from the Netherlands and compares the COVIDFIRST condition to the Baseline condition. Controls include gender, age groups, employment status, education, immigrant status, family status and number of family members, equivalised household income (coded into five quantiles) and a dummy to define the position of the Macron Speech question (see Section 3.1 for more details). All controls are omitted to enhance readability. Robust standard errors clustered at the province level are in parentheses $* p<0.1 ; * * \quad p<0.05 ; * * * p<0.01$ 
Table B26: Effects of Covidfirst vs Baseline - Netherlands: Taxation outcomes

\begin{tabular}{|c|c|c|c|c|c|c|c|c|c|}
\hline & $\begin{array}{l}\text { Regulate } \\
\text { Markets }\end{array}$ & $\begin{array}{l}\text { +Taxes } \\
\text {-Poverty }\end{array}$ & $\begin{array}{c}\text { + Taxes } \\
+ \text { Health Exp. }\end{array}$ & $\begin{array}{c}\text { + Taxes } \\
\text { +Unemp. Welf. }\end{array}$ & $\begin{array}{l}\text { + Taxes } \\
+ \text { Pensions }\end{array}$ & $\begin{array}{l}\text { Too Many } \\
\text { Immigrants }\end{array}$ & $\begin{array}{l}\text { Health Exp. } \\
\text { to Natives }\end{array}$ & $\begin{array}{c}\text { General Tax } \\
\text { too High }\end{array}$ & $\begin{array}{l}\text { Self Tax } \\
\text { too High }\end{array}$ \\
\hline Covidfirst & $\begin{array}{r}-0.00396 \\
(0.0528)\end{array}$ & $\begin{array}{c}-0.109 * * \\
(0.0468)\end{array}$ & $\begin{array}{c}-0.0963^{* * *} \\
(0.0293)\end{array}$ & $\begin{array}{c}-0.0738 \\
(0.0429)\end{array}$ & $\begin{array}{c}-0.0926^{* *} \\
(0.0325)\end{array}$ & $\begin{array}{c}0.0151 \\
(0.0457)\end{array}$ & $\begin{array}{l}-0.0259 \\
(0.0367)\end{array}$ & $\begin{array}{c}0.0257 \\
(0.0270)\end{array}$ & $\begin{array}{c}0.0519 \\
(0.0446)\end{array}$ \\
\hline Observations & 2,071 & 2,071 & 2,071 & 2,071 & 2,071 & 2,071 & 2,071 & 2,071 & 2,071 \\
\hline R-squared & 0.007 & 0.015 & 0.012 & 0.009 & 0.035 & 0.017 & 0.035 & 0.012 & 0.021 \\
\hline
\end{tabular}

The table presents estimates from OLS models. The outcome variables are stated in the first row. The sample solely includes observations from the Netherlands and compares the COVIDFIRST condition to the Baseline condition. Controls include gender, age groups, employment status, education, immigrant status, family status and number of family members, equivalised household income (coded into five quantiles) and a dummy to define the position of the Macron Speech question (see Section 3.1 for more details). All controls are omitted to enhance readability. Robust standard errors clustered at the province level are in parentheses. $* p<0.1 ; * * p<0.05 ; * * * p<0.01$

Table B27: Effects of Covidfirst vs Baseline - Netherlands: Voting outcomes

\begin{tabular}{lcccccccccccccccc}
\hline & $\begin{array}{c}\text { Incumbent } \\
\text { Voting }\end{array}$ & $\begin{array}{c}\text { Populism } \\
\text { Voting }\end{array}$ & $\begin{array}{c}\text { Euroscept. } \\
\text { Voting }\end{array}$ & $\begin{array}{c}\text { Ideology } \\
\text { Left/right }\end{array}$ & $\begin{array}{c}\text { EU } \\
\text { benefit }\end{array}$ & $\begin{array}{c}\text { EU } \\
\text { efficacy }\end{array}$ & $\begin{array}{c}\text { Leave } \\
\text { EU }\end{array}$ & $\begin{array}{c}\text { Strong } \\
\text { Leader }\end{array}$ & $\begin{array}{c}\text { More } \\
\text { Privacy }\end{array}$ & $\begin{array}{c}\text { People } \\
\text { Power }\end{array}$ & $\begin{array}{c}\text { Free } \\
\text { Media }\end{array}$ & $\begin{array}{c}\text { Plutocra. } \\
\text { Covidfirst }\end{array}$ \\
& 0.0421 & $-0.0682^{* *}$ & $-0.0689^{* *}$ & 0.00962 & $-0.161^{* * *}$ & $-0.156^{* * *}$ & -0.0118 & 0.000585 & -0.0301 & -0.0483 & -0.00686 & -0.00161 \\
& $(0.0418)$ & $(0.0308)$ & $(0.0311)$ & $(0.0546)$ & $(0.0386)$ & $(0.0384)$ & $(0.0463)$ & $(0.0434)$ & $(0.0349)$ & $(0.0360)$ & $(0.0469)$ & $(0.0275)$ \\
& & & & & & & & & & & & & & & & \\
Observations & 2,071 & 2,071 & 2,071 & 2,071 & 2,071 & 2,071 & 2,071 & 2,071 & 2,071 & 2,071 & 2,071 & 2,071 \\
R-squared & 0.034 & 0.010 & 0.010 & 0.048 & 0.015 & 0.018 & 0.029 & 0.013 & 0.029 & 0.022 & 0.051 & 0.019 \\
\hline
\end{tabular}

The table presents estimates from OLS models. The outcome variables are stated in the first row. The sample solely includes observations from the Netherlands and compares the COVIDFIRST condition to the Baseline condition. Controls include gender, age groups, employment status, education, immigrant status, family status and number of family members, equivalised household income (coded into five quantiles) and a dummy to define the position of the Macron Speech question (see Section 3.1 for more details). All controls are omitted to enhance readability. Robust standard errors clustered at the province level are in parentheses. ${ }^{*} p<0.1 ; * * \quad 00.05 ; * * *<<0.01$

Table B28: Effects of Covidfirst vs Baseline - Netherlands: Identity outcomes

\begin{tabular}{|c|c|c|c|c|c|c|c|c|c|}
\hline & $\begin{array}{l}\text { Belong } \\
\text { Town }\end{array}$ & $\begin{array}{l}\text { Belong } \\
\text { Nation }\end{array}$ & $\begin{array}{l}\text { Belong } \\
\text { EU }\end{array}$ & $\begin{array}{l}\text { - Own Freedom } \\
+ \text { Public Safety }\end{array}$ & $\begin{array}{l}\text { - Own Freedom } \\
+ \text { Own Safety }\end{array}$ & $\begin{array}{l}\text { - Own Freedom } \\
\text { + Family Safety }\end{array}$ & $\begin{array}{c}\text { Global Human } \\
\text { Rights }\end{array}$ & $\begin{array}{c}\text { Respect } \\
\text { Traditions }\end{array}$ & $\begin{array}{c}\text { Less } \\
\text { Globalization } \\
\end{array}$ \\
\hline Covidfirst & $\begin{array}{l}-0.00668 \\
(0.0406)\end{array}$ & $\begin{array}{l}0.0677^{*} \\
(0.0375)\end{array}$ & $\begin{array}{l}-0.0497^{*} \\
(0.0269)\end{array}$ & $\begin{array}{l}-0.0349 \\
(0.0335)\end{array}$ & $\begin{array}{l}-0.0631^{*} \\
(0.0345)\end{array}$ & $\begin{array}{l}-0.0592 \\
(0.0462)\end{array}$ & $\begin{array}{c}0.0296 \\
(0.0356)\end{array}$ & $\begin{array}{c}0.0594 \\
(0.0362)\end{array}$ & $\begin{array}{l}0.00482 \\
(0.0369)\end{array}$ \\
\hline Observations & 2,071 & 2,071 & 2,071 & 2,071 & 2,071 & 2,071 & 2,071 & 2,071 & 2,071 \\
\hline R-squared & 0.019 & 0.033 & 0.016 & 0.009 & 0.009 & 0.020 & 0.020 & 0.043 & 0.009 \\
\hline
\end{tabular}

The table presents estimates from OLS models. The outcome variables are stated in the first row. The sample solely includes observations from the Netherlands and compares the COVIDFIRST condition to the Baseline condition. Controls include gender, age groups, employment status, education, immigrant status, family status and number of family members, equivalised household income (coded into five quantiles) and a dummy to define the position of the Macron Speech question (see Section 3.1 for more income (coded into five quantiles) and a dummy to define the position of the Macron Speech question (see Section 3.1 for more
details). All controls are omitted to enhance readability. Robust standard errors clustered at the province level are in parentheses. details). All controls are omitted to enhance readability. Robust standard errors clustered at the province level are in parentheses.
$*^{*} p<0.1 ; * * \quad p<0.05 ; * * \quad p<0.01$ 


\section{B.3.4 Spain}

Table B29: Effects of Covidfirst vs Baseline - Spain: Trust outcomes

\begin{tabular}{|c|c|c|c|c|c|c|c|c|}
\hline & $\begin{array}{l}\text { Macron } \\
\text { Speech }\end{array}$ & $\begin{array}{c}\text { Trust } \\
\text { Politicians } \\
\end{array}$ & $\begin{array}{l}\text { Social } \\
\text { Trust }\end{array}$ & $\begin{array}{c}\text { Trust } \\
\text { Government }\end{array}$ & $\begin{array}{l}\text { Trust } \\
\text { Police }\end{array}$ & $\begin{array}{l}\text { Trust } \\
\text { Media }\end{array}$ & $\begin{array}{c}\text { Trust } \\
\text { Science }\end{array}$ & $\begin{array}{l}\text { Trust } \\
\text { EU }\end{array}$ \\
\hline Covidfirst & $\begin{array}{l}-0.0583 \\
(0.0370)\end{array}$ & $\begin{array}{l}-0.00136 \\
(0.0429)\end{array}$ & $\begin{array}{c}-0.224^{* * *} \\
(0.0472)\end{array}$ & $\begin{array}{c}0.0246 \\
(0.0472)\end{array}$ & $\begin{array}{l}0.168^{* *} \\
(0.0749)\end{array}$ & $\begin{array}{l}-0.0735 \\
(0.0524)\end{array}$ & $\begin{array}{c}0.141^{* * *} \\
(0.0392)\end{array}$ & $\begin{array}{c}-0.0609^{* *} \\
(0.0284)\end{array}$ \\
\hline Observations & 2,000 & 2,000 & 2,000 & 2,000 & 2,000 & 2,000 & 2,000 & 2,000 \\
\hline R-squared & 0.041 & 0.010 & 0.044 & 0.008 & 0.019 & 0.005 & 0.024 & 0.021 \\
\hline
\end{tabular}

The table presents estimates from OLS models. The outcome variables are stated in the first row. The sample solely includes observations from Spain and compares the COVIDFIRST condition to the Baseline condition. Controls include gender, age groups, employment status, education, immigrant status, family status and number of family members, equivalised household income (coded into five quantiles) and a dummy to define the position of the Macron Speech question (see Section 3.1 for more details). All controls are omitted to enhance readability. Robust standard errors clustered at the province level are in parentheses.

$p<0.1 ; * * p<0.05 ; * * * p<0.01$

Table B30: Effects of Covidfirst vs Baseline - Spain: Taxation outcomes

\begin{tabular}{|c|c|c|c|c|c|c|c|c|c|}
\hline & $\begin{array}{l}\text { Regulate } \\
\text { Markets }\end{array}$ & $\begin{array}{l}+ \text { Taxes } \\
\text {-Poverty }\end{array}$ & $\begin{array}{c}\text { + Taxes } \\
+ \text { Health Exp. }\end{array}$ & $\begin{array}{c}\text { + Taxes } \\
\text { +Unemp. Welf. }\end{array}$ & $\begin{array}{l}\text { +Taxes } \\
+ \text { Pensions }\end{array}$ & $\begin{array}{l}\text { Too Many } \\
\text { Immigrants }\end{array}$ & $\begin{array}{c}\text { Health Exp. } \\
\text { to Natives }\end{array}$ & $\begin{array}{c}\text { General Tax } \\
\text { too High }\end{array}$ & $\begin{array}{l}\text { Self Tax } \\
\text { too High }\end{array}$ \\
\hline Covidfirst & $\begin{array}{c}0.0247 \\
(0.0419)\end{array}$ & $\begin{array}{c}-0.0718 \\
(0.0444)\end{array}$ & $\begin{array}{c}0.0150 \\
(0.0561)\end{array}$ & $\begin{array}{l}-0.0107 \\
(0.0430)\end{array}$ & $\begin{array}{l}-0.0142 \\
(0.0407)\end{array}$ & $\begin{array}{l}-0.0621 \\
(0.0457)\end{array}$ & $\begin{array}{c}-0.0954^{* *} \\
(0.0414)\end{array}$ & $\begin{array}{c}0.0153 \\
(0.0364)\end{array}$ & $\begin{array}{c}-0.0228 \\
(0.0519)\end{array}$ \\
\hline Observations & 2,000 & 2,000 & 2,000 & 2,000 & 2,000 & 2,000 & 2,000 & 2,000 & 2,000 \\
\hline R-squared & 0.027 & 0.010 & 0.009 & 0.005 & 0.011 & 0.037 & 0.042 & 0.013 & 0.018 \\
\hline
\end{tabular}

The table presents estimates from OLS models. The outcome variables are stated in the first row. The sample solely includes observations from Spain and compares the COVIDFIRST condition to the Baseline condition. Controls include gender, age groups, (coded into five quantiles) and a dummy to define the position of the Macron Speech question (see Section 3.1 for more details). All controls are omitted to enhance readability. Robust standard errors clustered at the province level are in parentheses.

All controls are omitted to enhance
$p<0.1 ; * * \quad p<0.05 ; * * * \quad p<0.01$

Table B31: Effects of Covidfirst vs Baseline - Spain: Voting outcomes

\begin{tabular}{|c|c|c|c|c|c|c|c|c|c|c|c|c|}
\hline & $\begin{array}{l}\text { Incumbent } \\
\text { Voting }\end{array}$ & $\begin{array}{c}\text { Populism } \\
\text { Voting }\end{array}$ & $\begin{array}{l}\text { Euroscept. } \\
\text { Voting }\end{array}$ & $\begin{array}{c}\text { Ideology } \\
\text { Left/right }\end{array}$ & $\begin{array}{c}\mathrm{EU} \\
\text { benefit }\end{array}$ & $\begin{array}{c}\text { EU } \\
\text { efficacy }\end{array}$ & $\begin{array}{c}\text { Leave } \\
\text { EU }\end{array}$ & $\begin{array}{l}\text { Strong } \\
\text { Leader }\end{array}$ & $\begin{array}{c}\text { More } \\
\text { Privacy }\end{array}$ & $\begin{array}{l}\text { People } \\
\text { Power }\end{array}$ & $\begin{array}{l}\text { Free } \\
\text { Media }\end{array}$ & Plutocra \\
\hline Covidfirst & $\begin{array}{l}0.00148 \\
(0.0370)\end{array}$ & $\begin{array}{c}0.0234 \\
(0.0508)\end{array}$ & $\begin{array}{c}0.0255 \\
(0.0517)\end{array}$ & $\begin{array}{c}0.0275 \\
(0.0576)\end{array}$ & $\begin{array}{r}-0.00643 \\
(0.0358)\end{array}$ & $\begin{array}{c}0.0507 \\
(0.0579)\end{array}$ & $\begin{array}{l}-0.0401 \\
(0.0382)\end{array}$ & $\begin{array}{c}-0.125^{* * *} \\
(0.0412)\end{array}$ & $\begin{array}{l}0.00950 \\
(0.0399)\end{array}$ & $\begin{array}{c}-0.115^{* *} \\
(0.0461)\end{array}$ & $\begin{array}{c}0.0403 \\
(0.0533)\end{array}$ & $\begin{array}{c}0.0266 \\
(0.0562)\end{array}$ \\
\hline Observations & 2,000 & 2,000 & 2,000 & 2,000 & 2,000 & 2,000 & 2,000 & 2,000 & 2,000 & 2,000 & 2,000 & 2,000 \\
\hline R-squared & 0.004 & 0.007 & 0.009 & 0.015 & 0.067 & 0.031 & 0.021 & 0.023 & 0.009 & 0.016 & 0.016 & 0.014 \\
\hline
\end{tabular}

The table presents estimates from OLS models. The outcome variables are stated in the first row. The sample solely includes observations from Spain and compares the COVIDFIRST condition to the Baseline condition. Controls include gender, age groups, employment status, education, immigrant status, family status and number of family members, equivalised household income (coded into five quantiles) and a dummy to define the position of the Macron Speech question (see Section 3.1 for more details). All controls are omitted to enhance readability. Robust standard errors clustered at the province level are in parentheses.

$p<0.1 ; * * p<0.05 ; * * * p<0.01$ 
Table B32: Effects of Covidfirst vs Baseline - Spain: Identity outcomes

\begin{tabular}{lcccccccccc}
\hline & $\begin{array}{c}\text { Belong } \\
\text { Town }\end{array}$ & $\begin{array}{c}\text { Belong } \\
\text { Nation }\end{array}$ & $\begin{array}{c}\text { Belong } \\
\text { EU }\end{array}$ & $\begin{array}{c}\text { - Own Freedom } \\
\text { + Public Safety }\end{array}$ & $\begin{array}{c}\text { - Own Freedom } \\
\text { + Own Safety }\end{array}$ & $\begin{array}{c}\text { - Own Freedom } \\
\text { + Family Safety }\end{array}$ & $\begin{array}{c}\text { Global Human } \\
\text { Rights }\end{array}$ & $\begin{array}{c}\text { Respect } \\
\text { Traditions }\end{array}$ & $\begin{array}{c}\text { Less } \\
\text { Globalization }\end{array}$ \\
\hline \multirow{2}{*}{ 1.Covidfirst } & 0.0250 & 0.0158 & -0.0252 & 0.0320 & -0.00581 & -0.0281 & -0.00553 & 0.0375 & -0.0641 \\
& $(0.0377)$ & $(0.0329)$ & $(0.0277)$ & $(0.0367)$ & $(0.0510)$ & $(0.0359)$ & $(0.0392)$ & $(0.0535)$ & $(0.0428)$ \\
& & & & & & & & & \\
Observations & 2,000 & 2,000 & 2,000 & 2,000 & 2,000 & 2,000 & 2,000 & 2,000 & 2,000 \\
R-squared & 0.023 & 0.013 & 0.030 & 0.006 & 0.010 & 0.023 & 0.017 & 0.038 & 0.011 \\
\hline
\end{tabular}

The table presents estimates from OLS models. The outcome variables are stated in the first row. The sample solely includes observations from Spain and compares the COVIDFIRST condition to the Baseline condition. Controls include gender, age groups, employment status, education, immigrant status, family status and number of family members, equivalised household income (coded into five quantiles) and a dummy to define the position of the Macron Speech question (see Section 3.1 for more details). All controls are omitted to enhance readability. Robust standard errors clustered at the province level are in parentheses. $p<0.1$ * $^{* *} p<0.05$; $^{* * *} p<0.01$ 


\section{B.4 Heterogeneity analysis: perceptions of COVID-19}

\section{B.4.1 Exposure to the virus}

Table B33: Heterogeneous effects of having contracted the virus: Trust

\begin{tabular}{|c|c|c|c|c|c|c|c|c|}
\hline & $\begin{array}{l}\text { Macron } \\
\text { Speech }\end{array}$ & $\begin{array}{c}\text { Trust } \\
\text { Politicians } \\
\end{array}$ & $\begin{array}{c}\text { Social } \\
\text { Trust }\end{array}$ & $\begin{array}{c}\text { Trust } \\
\text { Government }\end{array}$ & $\begin{array}{l}\text { Trust } \\
\text { Police } \\
\end{array}$ & $\begin{array}{c}\text { Trust } \\
\text { Media }\end{array}$ & $\begin{array}{c}\text { Trust } \\
\text { Science }\end{array}$ & $\begin{array}{c}\text { Trust } \\
\text { EU }\end{array}$ \\
\hline Covidfirst & $\begin{array}{c}-0.144^{* * *} \\
(0.0208)\end{array}$ & $\begin{array}{c}-0.0397^{* *} \\
(0.0197)\end{array}$ & $\begin{array}{c}-0.130 * * * \\
(0.0269)\end{array}$ & $\begin{array}{c}0.00387 \\
(0.0214)\end{array}$ & $\begin{array}{c}0.0808^{* * *} \\
(0.0276)\end{array}$ & $\begin{array}{c}-0.0849^{* * *} \\
(0.0209)\end{array}$ & $\begin{array}{c}0.0883 * * * \\
(0.0229)\end{array}$ & $\begin{array}{c}-0.121 * * * \\
(0.0205)\end{array}$ \\
\hline Contracted & $\begin{array}{l}0.00897 \\
(0.0186)\end{array}$ & $\begin{array}{l}0.00976 \\
(0.0175)\end{array}$ & $\begin{array}{c}0.0387^{* * *} \\
(0.0137)\end{array}$ & $\begin{array}{c}0.00625 \\
(0.0173)\end{array}$ & $\begin{array}{c}0.0266 \\
(0.0175)\end{array}$ & $\begin{array}{c}0.0112 \\
(0.0205)\end{array}$ & $\begin{array}{c}-0.00142 \\
(0.0244)\end{array}$ & $\begin{array}{c}0.0194 \\
(0.0190)\end{array}$ \\
\hline Covidfirst*contracted & $\begin{array}{c}0.0341 \\
(0.0268)\end{array}$ & $\begin{array}{c}0.0304 \\
(0.0206)\end{array}$ & $\begin{array}{l}0.00160 \\
(0.0211)\end{array}$ & $\begin{array}{c}0.0200 \\
(0.0194)\end{array}$ & $\begin{array}{l}-0.0105 \\
(0.0188)\end{array}$ & $\begin{array}{c}0.0172 \\
(0.0259)\end{array}$ & $\begin{array}{c}0.0207 \\
(0.0240)\end{array}$ & $\begin{array}{c}0.0189 \\
(0.0212)\end{array}$ \\
\hline Observations & 8,235 & 8,235 & 8,235 & 8,235 & 8,235 & 8,235 & 8,235 & 8,235 \\
\hline R-squared & 0.064 & 0.184 & 0.064 & 0.119 & 0.034 & 0.145 & 0.046 & 0.028 \\
\hline
\end{tabular}

The table presents estimates from OLS models. The outcome variables are stated in the first row. The analysis interacts COVIDFIRST with an indicator variable indicating whether the respondent (or someone in his/her circle) contracted the virus. Controls include gender, age groups, employment status, education, immigrant status, family status and number of family members, equivalised household income (coded into five quantiles), a dummy to define the position of the Macron Speech question (see Section 3.1 for more details) and country fixed effects. All controls are omitted to enhance readability. Robust standard errors clustered at the province level are in parentheses. ${ }^{*} p<0.1$; ** $p<0.05 ; * * * p<0.01$

Table B34: Heterogeneous effects of having contracted the virus: Taxation

\begin{tabular}{|c|c|c|c|c|c|c|c|c|c|}
\hline & $\begin{array}{l}\text { Regulate } \\
\text { Markets }\end{array}$ & $\begin{array}{l}\text { + Taxes } \\
\text {-Poverty }\end{array}$ & $\begin{array}{c}\text { +Taxes } \\
+ \text { Health Exp. }\end{array}$ & $\begin{array}{c}\text { + Taxes } \\
\text { +Unemp. Welf. }\end{array}$ & $\begin{aligned} &+ \text { Taxes } \\
&+ \text { Pensions }\end{aligned}$ & $\begin{array}{c}\text { Too Many } \\
\text { Immigrants }\end{array}$ & $\begin{array}{c}\text { Health Exp. } \\
\text { to Natives }\end{array}$ & $\begin{array}{c}\text { General Tax } \\
\text { too High }\end{array}$ & $\begin{array}{l}\text { Self Tax } \\
\text { too High }\end{array}$ \\
\hline Covidfirst & $\begin{array}{l}-0.0259 \\
(0.0227)\end{array}$ & $\begin{array}{c}-0.0987^{* * *} \\
(0.0228)\end{array}$ & $\begin{array}{c}-0.0711^{* * * *} \\
(0.0230)\end{array}$ & $\begin{array}{c}-0.0583^{* * *} \\
(0.0222)\end{array}$ & $\begin{array}{c}-0.0711^{* * *} \\
(0.0209)\end{array}$ & $\begin{array}{l}-0.0137 \\
(0.0235)\end{array}$ & $\begin{array}{c}-0.0653^{* * *} \\
(0.0210)\end{array}$ & $\begin{array}{c}0.0292 \\
(0.0199)\end{array}$ & $\begin{array}{c}0.0568^{* *} \\
(0.0255)\end{array}$ \\
\hline Contracted & $\begin{array}{c}-0.0401^{* *} \\
(0.0202)\end{array}$ & $\begin{array}{c}0.0240 \\
(0.0154)\end{array}$ & $\begin{array}{l}-0.00327 \\
(0.0173)\end{array}$ & $\begin{array}{l}0.00854 \\
(0.0155)\end{array}$ & $\begin{array}{l}0.00293 \\
(0.0165)\end{array}$ & $\begin{array}{l}0.00847 \\
(0.0228)\end{array}$ & $\begin{array}{l}0.00597 \\
(0.0225)\end{array}$ & $\begin{array}{l}0.0253^{*} \\
(0.0152)\end{array}$ & $\begin{array}{c}0.0478^{* * *} \\
(0.0180)\end{array}$ \\
\hline Covidfirst* ${ }^{*}$ contracted & $\begin{array}{c}0.0452^{* *} \\
(0.0215)\end{array}$ & $\begin{array}{c}0.0245 \\
(0.0192)\end{array}$ & $\begin{array}{l}0.0470^{*} \\
(0.0270)\end{array}$ & $\begin{array}{l}0.00953 \\
(0.0217)\end{array}$ & $\begin{array}{c}0.0219 \\
(0.0218)\end{array}$ & $\begin{array}{l}-0.0315 \\
(0.0241)\end{array}$ & $\begin{array}{l}-0.0188 \\
(0.0242)\end{array}$ & $\begin{array}{l}-0.0352^{*} \\
(0.0182)\end{array}$ & $\begin{array}{c}-0.0443^{* *} \\
(0.0224)\end{array}$ \\
\hline Observations & 8,235 & 8,235 & 8,235 & 8,235 & 8,235 & 8,235 & 8,235 & 8,235 & 8,235 \\
\hline R-squared & 0.073 & 0.017 & 0.053 & 0.055 & 0.046 & 0.027 & 0.019 & 0.125 & 0.106 \\
\hline
\end{tabular}

The table presents estimates from OLS models. The outcome variables are stated in the first row. The analysis interacts COVIDFIRST with an indicator variable indicating whether the respondent (or someone in his/her circle) contracted the virus. Controls include gender, age groups, employment status, education, immigrant status, family status and number of family members, equivalised household income (coded into five quantiles), a dummy to define the position of the Macron Speech question (see Section 3.1 for more details) and country fixed effects. All controls are omitted to enhance readability. Robust standard errors clustered at the province level are in parentheses. ${ }^{*} p<0.1 ; * * p<0.05 ; * * * p<0.01$ 
Table B35: Heterogeneous effects of having contracted the virus: Voting

\begin{tabular}{|c|c|c|c|c|c|c|c|c|c|c|c|c|}
\hline & $\begin{array}{c}\text { Incumbent } \\
\text { Voting }\end{array}$ & $\begin{array}{c}\text { Populism } \\
\text { Voting }\end{array}$ & $\begin{array}{c}\text { Euroscept. } \\
\text { Voting }\end{array}$ & $\begin{array}{c}\text { Ideology } \\
\text { Left/right }\end{array}$ & $\begin{array}{c}\text { EU } \\
\text { benefit }\end{array}$ & $\begin{array}{c}\text { EU } \\
\text { efficacy }\end{array}$ & $\begin{array}{c}\text { Leave } \\
\text { EU }\end{array}$ & $\begin{array}{l}\text { Strong } \\
\text { Leader }\end{array}$ & $\begin{array}{c}\text { More } \\
\text { Privacy }\end{array}$ & $\begin{array}{l}\text { People } \\
\text { Power }\end{array}$ & $\begin{array}{c}\text { Free } \\
\text { Media }\end{array}$ & Plutocra. \\
\hline Covidfirst & $\begin{array}{c}0.0190 \\
(0.0214)\end{array}$ & $\begin{array}{c}-0.0164 \\
(0.0220)\end{array}$ & $\begin{array}{l}-0.00917 \\
(0.0222)\end{array}$ & $\begin{array}{c}0.0328 \\
(0.0232)\end{array}$ & $\begin{array}{c}-0.105^{* * *} \\
(0.0212)\end{array}$ & $\begin{array}{c}-0.0999^{* * *} \\
(0.0241)\end{array}$ & $\begin{array}{c}0.0135 \\
(0.0225)\end{array}$ & $\begin{array}{c}-0.0547^{* *} \\
(0.0257)\end{array}$ & $\begin{array}{c}-0.0371^{*} \\
(0.0222)\end{array}$ & $\begin{array}{c}-0.0514^{* *} \\
(0.0235)\end{array}$ & $\begin{array}{c}-0.000421 \\
(0.0240)\end{array}$ & $\begin{array}{c}-0.000965 \\
(0.0236)\end{array}$ \\
\hline Contracted & $\begin{array}{l}-0.0305^{*} \\
(0.0183)\end{array}$ & $\begin{array}{c}0.0199 \\
(0.0201)\end{array}$ & $\begin{array}{c}0.0227 \\
(0.0201)\end{array}$ & $\begin{array}{l}0.0389^{*} \\
(0.0207)\end{array}$ & $\begin{array}{c}0.0262 \\
(0.0166)\end{array}$ & $\begin{array}{c}0.0213 \\
(0.0182)\end{array}$ & $\begin{array}{c}0.00863 \\
(0.0181)\end{array}$ & $\begin{array}{c}0.0136 \\
(0.0196)\end{array}$ & $\begin{array}{c}-0.0200 \\
(0.0229)\end{array}$ & $\begin{array}{c}0.0107 \\
(0.0162)\end{array}$ & $\begin{array}{l}-0.00937 \\
(0.0181)\end{array}$ & $\begin{array}{c}0.0127 \\
(0.0178)\end{array}$ \\
\hline Covidfirst*contracted & $\begin{array}{l}0.0411^{*} \\
(0.0226)\end{array}$ & $\begin{array}{l}0.00725 \\
(0.0209)\end{array}$ & $\begin{array}{l}0.000967 \\
(0.0210)\end{array}$ & $\begin{array}{l}-0.0346 \\
(0.0222)\end{array}$ & $\begin{array}{c}0.0202 \\
(0.0209)\end{array}$ & $\begin{array}{c}0.0507^{* *} \\
(0.0242)\end{array}$ & $\begin{array}{c}-0.0310 \\
(0.0214)\end{array}$ & $\begin{array}{l}-0.0230 \\
(0.0227)\end{array}$ & $\begin{array}{c}0.0191 \\
(0.0264)\end{array}$ & $\begin{array}{l}-0.0348^{*} \\
(0.0209)\end{array}$ & $\begin{array}{c}0.0319 \\
(0.0246)\end{array}$ & $\begin{array}{r}-0.00546 \\
(0.0207)\end{array}$ \\
\hline & & 8 & & 8,2 & 8,235 & 8,235 & 8,235 & 8,2 & 8,2 & 8,235 & 8,235 & 8,235 \\
\hline $\mathrm{R}$-squared & 0.015 & 0.084 & 0.064 & 0.054 & 0.070 & 0.061 & 0.042 & 0.026 & 0.037 & 0.041 & 0.078 & 0.045 \\
\hline
\end{tabular}

The table presents estimates from OLS models. The outcome variables are stated in the first row. The analysis interacts COVIDFIRST with an indicator variable indicating whether the respondent (or someone in his/her circle) contracted the virus. Controls include gender, age groups, employment status, education, immigrant status, family status and number of family members, equivalised household income (coded into five quantiles), a dummy to define the position of the Macron Speech question (see Section 3.1 for more details) and country fixed effects. All controls are omitted to enhance readability. Robust standard errors clustered at the province level are in parentheses. ${ }^{*} p<0.1 ; * * p<0.05 ; * * * p<0.01$

Table B36: Heterogeneous effects of having contracted the virus: Identity

\begin{tabular}{|c|c|c|c|c|c|c|c|c|c|}
\hline & $\begin{array}{l}\text { Belong } \\
\text { Town }\end{array}$ & $\begin{array}{l}\text { Belong } \\
\text { Nation }\end{array}$ & $\begin{array}{c}\text { Belong } \\
\text { EU }\end{array}$ & $\begin{array}{l}\text { - Own Freedom } \\
+ \text { Public Safety }\end{array}$ & $\begin{array}{l}\text { - Own Freedom } \\
+ \text { Own Safety }\end{array}$ & $\begin{array}{l}\text { - Own Freedom } \\
+ \text { Family Safety }\end{array}$ & $\begin{array}{c}\text { Global Human } \\
\text { Rights }\end{array}$ & $\begin{array}{c}\text { Respect } \\
\text { Traditions }\end{array}$ & $\begin{array}{c}\text { Less } \\
\text { Globalization } \\
\end{array}$ \\
\hline Covidfirst & $\begin{array}{l}-0.0154 \\
(0.0234)\end{array}$ & $\begin{array}{c}0.0256 \\
(0.0227)\end{array}$ & $\begin{array}{c}-0.0771^{* * *} \\
(0.0199)\end{array}$ & $\begin{array}{l}-0.0196 \\
(0.0225)\end{array}$ & $\begin{array}{l}-0.00777 \\
(0.0236)\end{array}$ & $\begin{array}{c}-0.0218 \\
(0.0236)\end{array}$ & $\begin{array}{l}0.00440 \\
(0.0229)\end{array}$ & $\begin{array}{l}0.00994 \\
(0.0239)\end{array}$ & $\begin{array}{l}-0.00300 \\
(0.0222)\end{array}$ \\
\hline Contracted & $\begin{array}{c}0.000460 \\
(0.0198)\end{array}$ & $\begin{array}{c}0.0159 \\
(0.0226)\end{array}$ & $\begin{array}{c}0.0118 \\
(0.0183)\end{array}$ & $\begin{array}{c}0.0379^{* *} \\
(0.0157)\end{array}$ & $\begin{array}{c}0.0149 \\
(0.0192)\end{array}$ & $\begin{array}{c}0.0235 \\
(0.0211)\end{array}$ & $\begin{array}{l}0.00480 \\
(0.0162)\end{array}$ & $\begin{array}{c}0.0153 \\
(0.0131)\end{array}$ & $\begin{array}{l}0.00624 \\
(0.0179)\end{array}$ \\
\hline Covidfirst*contracted & $\begin{array}{c}0.0186 \\
(0.0210)\end{array}$ & $\begin{array}{l}0.00500 \\
(0.0209)\end{array}$ & $\begin{array}{c}0.0232 \\
(0.0208)\end{array}$ & $\begin{array}{c}-0.00924 \\
(0.0182)\end{array}$ & $\begin{array}{l}0.00525 \\
(0.0240)\end{array}$ & $\begin{array}{l}-0.0189 \\
(0.0215)\end{array}$ & $\begin{array}{l}0.00751 \\
(0.0211)\end{array}$ & $\begin{array}{r}-0.00900 \\
(0.0156)\end{array}$ & $\begin{array}{c}-0.00904 \\
(0.0245)\end{array}$ \\
\hline Observations & 8,235 & 8,235 & 8,235 & 8,235 & 8,235 & 8,235 & 8,235 & 8,235 & 8,235 \\
\hline R-squared & 0.030 & 0.029 & 0.038 & 0.011 & 0.016 & 0.026 & 0.031 & 0.052 & 0.049 \\
\hline
\end{tabular}

The table presents estimates from OLS models. The outcome variables are stated in the first row. The analysis interacts COVIDFIRST with an indicator variable indicating whether the respondent (or someone in his/her circle) contracted the virus. Controls inclucter include gender, age groups, employment status, education, immigrant status, family status and number of family members, equiv3.1 for more details) and country fixed effects. All controls are omitted to enhance readability. Robust standard errors clustered at the province level are in parentheses. ${ }^{*} p<0.1 ;{ }^{* *} p<0.05 ; * * * 0<0.01$ 


\section{B.4.2 Compliance with anti-diffusion measures}

Table B37: Heterogeneous effects of compliance with anti-diffusion measures: Trust

\begin{tabular}{lcccccccc}
\hline & $\begin{array}{c}\text { Macron } \\
\text { Speech }\end{array}$ & $\begin{array}{c}\text { Trust } \\
\text { Politicians }\end{array}$ & $\begin{array}{c}\text { Social } \\
\text { Trust }\end{array}$ & $\begin{array}{c}\text { Trust } \\
\text { Government }\end{array}$ & $\begin{array}{c}\text { Trust } \\
\text { Police }\end{array}$ & $\begin{array}{c}\text { Trust } \\
\text { Media }\end{array}$ & $\begin{array}{c}\text { Trust } \\
\text { Science }\end{array}$ & $\begin{array}{c}\text { Trust } \\
\text { EU }\end{array}$ \\
\hline \multirow{3}{*}{ Covidfirst } & & & & & & & & \\
& $-0.143^{* * *}$ & $-0.0370^{*}$ & $-0.129^{* * *}$ & 0.00709 & $0.0846^{* * *}$ & $-0.0816^{* * *}$ & $0.0921^{* * *}$ & $-0.118^{* * *}$ \\
Obedience & $(0.0209)$ & $(0.0193)$ & $(0.0271)$ & $(0.0208)$ & $(0.0260)$ & $(0.0202)$ & $(0.0231)$ & $(0.0205)$ \\
& 0.0130 & $0.125^{* * *}$ & -0.00675 & $0.182^{* * *}$ & $0.198^{* * *}$ & $0.176^{* * *}$ & $0.237^{* * *}$ & $0.136^{* * *}$ \\
Covidfirst*obedience & $(0.0198)$ & $(0.0200)$ & $(0.0203)$ & $(0.0167)$ & $(0.0192)$ & $(0.0206)$ & $(0.0215)$ & $(0.0213)$ \\
& $0.0403^{*}$ & $0.0478^{* *}$ & $-0.0582^{* *}$ & $0.0568^{* * *}$ & -0.0147 & 0.0327 & $0.0797^{* * *}$ & 0.0192 \\
& $(0.0224)$ & $(0.0220)$ & $(0.0250)$ & $(0.0208)$ & $(0.0233)$ & $(0.0233)$ & $(0.0288)$ & $(0.0260)$ \\
Observations & & & & & & & & \\
R-squared & 8,235 & 8,235 & 8,235 & 8,235 & 8,235 & 8,235 & 8,235 & 8,235 \\
\hline
\end{tabular}

The table presents estimates from OLS models. The outcome variables are stated in the first row. The analysis interacts COVIDFIRST with a variable indicating the respondent's level of compliance with anti-diffusion measures. Controls include gender, age groups, employment status, education, immigrant status, family status and number of family members, equivalised household income (coded into five quantiles), a dummy to define the position of the Macron Speech question (see Section 3.1 for more details) and country fixed effects. All controls are omitted to enhance readability. Robust standard errors clustered at the province level are in parentheses. ${ }^{*} p<0.1 ; * * p<0.05 ; * * * 00.01$

Table B38: Heterogeneous effects of compliance with anti-diffusion measures: Taxation

\begin{tabular}{|c|c|c|c|c|c|c|c|c|c|}
\hline & $\begin{array}{l}\text { Regulate } \\
\text { Markets }\end{array}$ & $\begin{array}{l}\text { +Taxes } \\
\text {-Poverty }\end{array}$ & $\begin{array}{c}\text { +Taxes } \\
+ \text { Health Exp. }\end{array}$ & $\begin{array}{c}\text { +Taxes } \\
\text { +Unemp. Welf. }\end{array}$ & $\begin{array}{l}\text { + Taxes } \\
+ \text { +Pensions }\end{array}$ & $\begin{array}{l}\text { Too Many } \\
\text { Immigrants }\end{array}$ & $\begin{array}{l}\text { Health Exp. } \\
\text { to Natives }\end{array}$ & $\begin{array}{c}\text { General Tax } \\
\text { too High }\end{array}$ & $\begin{array}{l}\text { Self Tax } \\
\text { too High }\end{array}$ \\
\hline Covidfirst & $\begin{array}{l}-0.0254 \\
(0.0234)\end{array}$ & $\begin{array}{c}-0.0957^{* * * *} \\
(0.0227)\end{array}$ & $\begin{array}{c}-0.0677^{* * * *} \\
(0.0245)\end{array}$ & $\begin{array}{c}-0.0558^{* *} \\
(0.0225)\end{array}$ & $\begin{array}{c}-0.0682^{* * *} \\
(0.0220)\end{array}$ & $\begin{array}{l}-0.0142 \\
(0.0235)\end{array}$ & $\begin{array}{c}-0.0668^{* * *} \\
(0.0208)\end{array}$ & $\begin{array}{c}0.0293 \\
(0.0200)\end{array}$ & $\begin{array}{c}0.0578^{* *} \\
(0.0261)\end{array}$ \\
\hline Obedience & $\begin{array}{c}0.110^{\text {**** }} \\
(0.0215)\end{array}$ & $\begin{array}{c}0.117^{* * *} \\
(0.0221)\end{array}$ & $\begin{array}{c}0.192^{* * * *} \\
(0.0212)\end{array}$ & $\begin{array}{c}0.142^{* * * *} \\
(0.0230)\end{array}$ & $\begin{array}{c}0.175^{* * *} \\
(0.0214)\end{array}$ & $\begin{array}{l}-0.0244 \\
(0.0205)\end{array}$ & $\begin{array}{c}-0.1000^{* * * *} \\
(0.0215)\end{array}$ & $\begin{array}{l}-0.0257 \\
(0.0194)\end{array}$ & $\begin{array}{l}-0.0186 \\
(0.0214)\end{array}$ \\
\hline Covidfirst*obedience & $\begin{array}{l}-0.0165 \\
(0.0266)\end{array}$ & $\begin{array}{c}0.0281 \\
(0.0255)\end{array}$ & $\begin{array}{l}-0.00315 \\
(0.0235)\end{array}$ & $\begin{array}{l}0.00661 \\
(0.0275)\end{array}$ & $\begin{array}{l}-0.0223 \\
(0.0244)\end{array}$ & $\begin{array}{l}-0.0298 \\
(0.0251)\end{array}$ & $\begin{array}{l}-0.0247 \\
(0.0252)\end{array}$ & $\begin{array}{c}-0.0448^{* *} \\
(0.0223)\end{array}$ & $\begin{array}{l}-0.0446^{*} \\
(0.0240)\end{array}$ \\
\hline Observations & 8,235 & 8,235 & 8,235 & 8,235 & 8,235 & 8,235 & 8,235 & 8,235 & 8,235 \\
\hline $\mathrm{R}$-squared & 0.081 & 0.031 & 0.082 & 0.073 & 0.068 & 0.029 & 0.032 & 0.128 & 0.108 \\
\hline
\end{tabular}

The table presents estimates from OLS models. The outcome variables are stated in the first row. The analysis interacts COVIDFIRST with a variable indicating the respondent's level of compliance with anti-diffusion measures. Controls include gender, age groups, employment status, education, immigrant status, family status and number of family members, equivalised household income (coded into five quantiles), a dummy to define the position of the Macron Speech question (see Section 3.1 for more details) and country fixed effects. All controls are omitted to enhance readability. Robust standard errors clustered at the province level are in parentheses. ${ }^{*} p<0.1 ;{ }^{* *} p<0.05 ;{ }^{* * *} p<0.01$ 
Table B39: Heterogeneous effects of compliance with anti-diffusion measures: Voting

\begin{tabular}{|c|c|c|c|c|c|c|c|c|c|c|c|c|}
\hline & $\begin{array}{c}\text { Incumbent } \\
\text { Voting }\end{array}$ & $\begin{array}{c}\text { Populism } \\
\text { Voting }\end{array}$ & $\begin{array}{c}\text { Euroscept. } \\
\text { Voting }\end{array}$ & $\begin{array}{c}\text { Ideology } \\
\text { Left/right }\end{array}$ & $\begin{array}{c}\text { EU } \\
\text { benefit }\end{array}$ & $\begin{array}{c}\text { EU } \\
\text { efficacy }\end{array}$ & $\begin{array}{c}\text { Leave } \\
\text { EU }\end{array}$ & $\begin{array}{l}\text { Strong } \\
\text { Leader } \\
\end{array}$ & $\begin{array}{c}\text { More } \\
\text { Privacy }\end{array}$ & $\begin{array}{l}\text { People } \\
\text { Power }\end{array}$ & $\begin{array}{c}\text { Free } \\
\text { Media } \\
\end{array}$ & Plutocra. \\
\hline Covidfi & $\begin{array}{c}0.0203 \\
(0.0214)\end{array}$ & $\begin{array}{c}-0.0157 \\
(0.0222)\end{array}$ & $\begin{array}{c}-0.00867 \\
(0.0225)\end{array}$ & $\begin{array}{c}0.0324 \\
(0.0239)\end{array}$ & $\begin{array}{c}-0.101^{* * *} * \\
(0.0213)\end{array}$ & $\begin{array}{c}-0.0971^{* * *} \\
(0.0237)\end{array}$ & $\begin{array}{c}0.0117 \\
(0.0221)\end{array}$ & $\begin{array}{c}-0.0553^{* *} \\
(0.0262)\end{array}$ & $\begin{array}{c}-0.0394^{*} \\
(0.0218)\end{array}$ & $\begin{array}{c}-0.0530^{* *} \\
(0.0229)\end{array}$ & $\begin{array}{c}0.000102 \\
(0.0242)\end{array}$ & $\begin{array}{c}-0.000918 \\
(0.0235)\end{array}$ \\
\hline $\mathrm{O}$ & $\begin{array}{r}0.136^{* * *} * \\
(0.0164)\end{array}$ & $\begin{array}{c}-0.0202 \\
(0.0179)\end{array}$ & $\begin{array}{l}-0.0293 \\
(0.0183)\end{array}$ & $\begin{array}{c}-0.107^{* * *} \\
(0.0206)\end{array}$ & $\begin{array}{c}0.132^{* * *} \\
(0.0213)\end{array}$ & $\begin{array}{c}0.0849^{* * *} \\
(0.0225)\end{array}$ & $\begin{array}{c}-0.118^{* * *} \\
(0.0243)\end{array}$ & $\begin{array}{c}-0.0605^{* *} \\
(0.0235)\end{array}$ & $\begin{array}{c}-0.119^{* * *} \\
(0.0202)\end{array}$ & $\begin{array}{c}-0.103^{* * *} \\
(0.0231)\end{array}$ & $\begin{array}{c}0.0331 \\
(0.0229)\end{array}$ & $\begin{array}{c}-0.0258 \\
(0.0232)\end{array}$ \\
\hline Covidfirst*obedience & $\begin{array}{r}-0.00496 \\
(0.0184)\end{array}$ & $\begin{array}{c}-0.0255 \\
(0.0220)\end{array}$ & $\begin{array}{l}-0.0157 \\
(0.0227)\end{array}$ & $\begin{array}{l}-0.0286 \\
(0.0241)\end{array}$ & $\begin{array}{l}0.00845 \\
(0.0252)\end{array}$ & $\begin{array}{c}0.0264 \\
(0.0262)\end{array}$ & $\begin{array}{c}-0.00362 \\
(0.0269)\end{array}$ & $\begin{array}{c}0.0136 \\
(0.0281)\end{array}$ & $\begin{array}{c}0.0153 \\
(0.0247)\end{array}$ & $\begin{array}{c}-0.0478^{* *} \\
(0.0233)\end{array}$ & $\begin{array}{l}-0.0322 \\
(0.0276)\end{array}$ & $\begin{array}{c}-0.0387 \\
(0.0288)\end{array}$ \\
\hline $\mathrm{Ol}$ & 8 & 8,235 & 8 & 8,23 & 8,235 & 8,235 & 8,235 & 8,2 & 8,235 & 8,235 & 8,235 & 8,235 \\
\hline $\mathrm{R}$-squared & 0.031 & 0.085 & 0.065 & 0.068 & 0.086 & 0.067 & 0.056 & 0.029 & 0.047 & 0.058 & 0.078 & 0.048 \\
\hline
\end{tabular}

The table presents estimates from OLS models. The outcome variables are stated in the first row. The analysis interacts COVIDFIRST with a variable indicating the respondent's level of compliance with anti-diffusion measures. Controls include gender, age groups, employment status, education, immigrant status, family status and number of family members, equivalised household income (coded into five quantiles), a dummy to define the position of the Macron Speech question (see Section 3.1 for more details) come (coded into five quantiles), a dummy to define the position of the Macron Speech question (see Section 3.1 for more details) are in parentheses. * $p<0.1 ; * * p<0.05 ; * * * p<0.01$

Table B40: Heterogeneous effects of compliance with anti-diffusion measures: Identity

\begin{tabular}{|c|c|c|c|c|c|c|c|c|c|}
\hline & $\begin{array}{l}\text { Belong } \\
\text { Town }\end{array}$ & $\begin{array}{l}\text { Belong } \\
\text { Nation }\end{array}$ & $\begin{array}{l}\text { Belong } \\
\text { EU }\end{array}$ & $\begin{array}{l}\text { - Own Freedom } \\
+ \text { Public Safety }\end{array}$ & $\begin{array}{l}\text { - Own Freedom } \\
+ \text { Own Safety }\end{array}$ & $\begin{array}{l}\text { - Own Freedom } \\
+ \text { Family Safety }\end{array}$ & $\begin{array}{c}\text { Global Human } \\
\text { Rights }\end{array}$ & $\begin{array}{c}\text { Respect } \\
\text { Traditions }\end{array}$ & $\begin{array}{c}\text { Less } \\
\text { Globalization }\end{array}$ \\
\hline Covidfirst & $\begin{array}{l}-0.0129 \\
(0.0228)\end{array}$ & $\begin{array}{c}0.0291 \\
(0.0214)\end{array}$ & $\begin{array}{c}-0.0741^{* * *} \\
(0.0201)\end{array}$ & $\begin{array}{l}-0.0149 \\
(0.0217)\end{array}$ & $\begin{array}{l}-0.00395 \\
(0.0226)\end{array}$ & $\begin{array}{l}-0.0176 \\
(0.0232)\end{array}$ & $\begin{array}{l}0.00781 \\
(0.0238)\end{array}$ & $\begin{array}{c}0.0120 \\
(0.0236)\end{array}$ & $\begin{array}{c}-0.00318 \\
(0.0223)\end{array}$ \\
\hline Obedience & $\begin{array}{c}0.156^{* * *} \\
(0.0228)\end{array}$ & $\begin{array}{c}0.187^{* * *} * \\
(0.0233)\end{array}$ & $\begin{array}{c}0.151^{* * * *} \\
(0.0209)\end{array}$ & $\begin{array}{c}0.227^{* * *} * \\
(0.0211)\end{array}$ & $\begin{array}{l}0.215^{* * *} * \\
(0.0228)\end{array}$ & $\begin{array}{c}0.239^{* * *} * \\
(0.0213)\end{array}$ & $\begin{array}{c}0.215^{* * *} * \\
(0.0274)\end{array}$ & $\begin{array}{c}0.107 * * * \\
(0.0216)\end{array}$ & $\begin{array}{l}-0.0197 \\
(0.0220)\end{array}$ \\
\hline Covidfirst*obedience & $\begin{array}{r}-0.0487^{*} \\
(0.0268)\end{array}$ & $\begin{array}{l}-0.0237 \\
(0.0262)\end{array}$ & $\begin{array}{l}0.00103 \\
(0.0253)\end{array}$ & $\begin{array}{l}-0.0167 \\
(0.0264)\end{array}$ & $\begin{array}{c}-0.000168 \\
(0.0261)\end{array}$ & $\begin{array}{l}-0.0101 \\
(0.0244)\end{array}$ & $\begin{array}{c}-0.0274 \\
(0.0299)\end{array}$ & $\begin{array}{c}-0.0349 \\
(0.0239)\end{array}$ & $\begin{array}{l}-0.0276 \\
(0.0259)\end{array}$ \\
\hline Observations & 8,235 & 8,235 & 8,235 & 8,235 & 8,235 & 8,235 & 8,235 & 8,235 & 8,235 \\
\hline R-squared & 0.044 & 0.055 & 0.058 & 0.052 & 0.058 & 0.074 & 0.067 & 0.059 & 0.051 \\
\hline
\end{tabular}

The table presents estimates from OLS models. The outcome variables are stated in the first row. The analysis interacts COVIDFIRST with a variable indicating the respondent's level of compliance with anti-diffusion measures. Controls include gender, age groups, employment status, education, immigrant status, family status and number of family members, equivalised household income (coded into five quantiles), a dummy to define the position of the Macron Speech question (see Section 3.1 for more details) and country fixed effects. All controls are omitted to enhance readability. Robust standard errors clustered at the province level are in parentheses. ${ }^{*} p<0.1 ; * * p<0.05 ; * * * p<0.01$ 


\section{B.4.3 Worried about own health due to COVID-19}

Table B41: Heterogeneous effects of concern with the epidemic: Trust

\begin{tabular}{|c|c|c|c|c|c|c|c|c|}
\hline & $\begin{array}{l}\text { Macron } \\
\text { Speech }\end{array}$ & $\begin{array}{c}\text { Trust } \\
\text { Politicians }\end{array}$ & $\begin{array}{l}\text { Social } \\
\text { Trust }\end{array}$ & $\begin{array}{c}\text { Trust } \\
\text { Government }\end{array}$ & $\begin{array}{l}\text { Trust } \\
\text { Police }\end{array}$ & $\begin{array}{c}\text { Trust } \\
\text { Media }\end{array}$ & $\begin{array}{c}\text { Trust } \\
\text { Science }\end{array}$ & $\begin{array}{c}\text { Trust } \\
\text { EU }\end{array}$ \\
\hline Covidfirst & $\begin{array}{c}-0.140 * * * \\
(0.0212)\end{array}$ & $\begin{array}{c}-0.0332^{*} \\
(0.0193)\end{array}$ & $\begin{array}{c}-0.126^{* * *} \\
(0.0272)\end{array}$ & $\begin{array}{l}0.00909 \\
(0.0211)\end{array}$ & $\begin{array}{c}0.0867^{* * *} \\
(0.0268)\end{array}$ & $\begin{array}{c}-0.0786^{* * *} \\
(0.0199)\end{array}$ & $\begin{array}{c}0.0931^{* * *} \\
(0.0225)\end{array}$ & $\begin{array}{c}-0.114^{* * *} \\
(0.0200)\end{array}$ \\
\hline Worried & $\begin{array}{c}0.0694^{* * *} \\
(0.0136)\end{array}$ & $\begin{array}{c}0.113^{* * *} \\
(0.0199)\end{array}$ & $\begin{array}{c}0.0578^{* *} \\
(0.0224)\end{array}$ & $\begin{array}{c}0.0908^{* * *} \\
(0.0223)\end{array}$ & $\begin{array}{c}0.109^{* * *} \\
(0.0216)\end{array}$ & $\begin{array}{c}0.113^{* * *} \\
(0.0207)\end{array}$ & $\begin{array}{c}0.0945^{* * *} \\
(0.0194)\end{array}$ & $\begin{array}{c}0.136^{* * *} \\
(0.0209)\end{array}$ \\
\hline Covidfirst* ${ }^{*}$ worried & $\begin{array}{l}-0.0138 \\
(0.0175)\end{array}$ & $\begin{array}{c}0.0317 \\
(0.0227)\end{array}$ & $\begin{array}{l}-0.0422^{*} \\
(0.0255)\end{array}$ & $\begin{array}{c}0.0371 \\
(0.0240)\end{array}$ & $\begin{array}{c}-0.00224 \\
(0.0224)\end{array}$ & $\begin{array}{c}0.0290 \\
(0.0215)\end{array}$ & $\begin{array}{c}0.0137 \\
(0.0227)\end{array}$ & $\begin{array}{l}-0.0107 \\
(0.0264)\end{array}$ \\
\hline Observations & 8,235 & 8,235 & 8,235 & 8,235 & 8,235 & 8,235 & 8,235 & 8,235 \\
\hline R-squared & 0.066 & 0.199 & 0.064 & 0.130 & 0.044 & 0.160 & 0.055 & 0.043 \\
\hline
\end{tabular}

The table presents estimates from OLS models. The outcome variables are stated in the first row. The analysis interacts COVIDFIRST with a variable indicating the respondent's level of concern with the epidemic. Controls include gender, age groups, employment status, education, immigrant status, family status and number of family members, equivalised household income (coded into five quantiles), a dummy to define the position of the Macron Speech question (see Section 3.1 for more details) and country fixed effects. All controls are omitted to enhance readability. Robust standard errors clustered at the province level are in parentheses. $* p<0.1 ; * * p<0.05 ; * * * p<0.01$

Table B42: Heterogeneous effects of concern with the epidemic: Taxation

\begin{tabular}{|c|c|c|c|c|c|c|c|c|c|}
\hline & $\begin{array}{l}\text { Regulate } \\
\text { Markets }\end{array}$ & $\begin{array}{c}\text { +Taxes } \\
\text {-Poverty }\end{array}$ & $\begin{array}{c}\text { + Taxes } \\
+ \text { Health Exp. }\end{array}$ & $\begin{array}{c}\text { +Taxes } \\
\text { +Unemp. Welf. }\end{array}$ & $\begin{array}{c}\text { + Taxes } \\
+ \text { Pensions }\end{array}$ & $\begin{array}{c}\text { Too Many } \\
\text { Immigrants }\end{array}$ & $\begin{array}{c}\text { Health Exp. } \\
\text { to Natives }\end{array}$ & $\begin{array}{c}\text { General Tax } \\
\text { too High }\end{array}$ & $\begin{array}{l}\text { Self Tax } \\
\text { too High }\end{array}$ \\
\hline Covidfirst & $\begin{array}{l}-0.0221 \\
(0.0230)\end{array}$ & $\begin{array}{c}-0.0937 * * * \\
(0.0231)\end{array}$ & $\begin{array}{c}-0.0678^{* * *} \\
(0.0236)\end{array}$ & $\begin{array}{c}-0.0537^{* *} \\
(0.0227)\end{array}$ & $\begin{array}{c}-0.0670^{* * * *} \\
(0.0209)\end{array}$ & $\begin{array}{l}-0.0120 \\
(0.0234)\end{array}$ & $\begin{array}{c}-0.0596^{* * *} \\
(0.0205)\end{array}$ & $\begin{array}{c}0.0306 \\
(0.0198)\end{array}$ & $\begin{array}{c}0.0609^{* *} \\
(0.0256)\end{array}$ \\
\hline Worried & $\begin{array}{c}0.0886^{* * *} \\
(0.0234)\end{array}$ & $\begin{array}{c}0.0646^{* * *} \\
(0.0197)\end{array}$ & $\begin{array}{c}0.0422^{* *} \\
(0.0186)\end{array}$ & $\begin{array}{c}0.0788^{* * *} \\
(0.0230)\end{array}$ & $\begin{array}{c}0.0654^{* * *} \\
(0.0179)\end{array}$ & $\begin{array}{l}0.0338^{*} \\
(0.0205)\end{array}$ & $\begin{array}{c}0.130^{* * *} \\
(0.0179)\end{array}$ & $\begin{array}{c}0.0211 \\
(0.0188)\end{array}$ & $\begin{array}{c}0.0659^{* * *} \\
(0.0193)\end{array}$ \\
\hline Covidfirst*worried & $\begin{array}{c}0.0597^{* *} \\
(0.0249)\end{array}$ & $\begin{array}{c}0.0579^{* *} \\
(0.0240)\end{array}$ & $\begin{array}{c}0.0557^{* *} \\
(0.0232)\end{array}$ & $\begin{array}{c}0.0397 \\
(0.0246)\end{array}$ & $\begin{array}{c}0.0561^{* *} \\
(0.0230)\end{array}$ & $\begin{array}{c}0.0169 \\
(0.0236)\end{array}$ & $\begin{array}{l}-0.0208 \\
(0.0264)\end{array}$ & $\begin{array}{l}-0.00984 \\
(0.0206)\end{array}$ & $\begin{array}{l}-0.0222 \\
(0.0235)\end{array}$ \\
\hline Observations & 8,235 & 8,235 & 8,235 & 8,235 & 8,235 & 8,235 & 8,235 & 8,235 & 8,235 \\
\hline R-squared & 0.088 & 0.025 & 0.057 & 0.064 & 0.056 & 0.029 & 0.032 & 0.125 & 0.108 \\
\hline
\end{tabular}

The table presents estimates from OLS models. The outcome variables are stated in the first row. The analysis interacts COVIDFIRST with a variable indicating the respondent's level of concern with the epidemic. Controls include gender, age groups, employment status, education, immigrant status, family status and number of family members, equivalised household income (coded into five quantiles), a dummy to define the position of the Macron Speech question (see Section 3.1 for more details) and country fixed effects. All controls are omitted to enhance readability. Robust standard errors clustered at the province level are in parentheses. ${ }^{*} p<0.1 ; * * p<0.05 ; * * * p<0.01$ 
Table B43: Heterogeneous effects of concern with the epidemic: Voting

\begin{tabular}{|c|c|c|c|c|c|c|c|c|c|c|c|c|}
\hline & $\begin{array}{c}\text { Incumbent } \\
\text { Voting }\end{array}$ & $\begin{array}{c}\text { Populism } \\
\text { Voting }\end{array}$ & $\begin{array}{c}\text { Euroscept. } \\
\text { Voting }\end{array}$ & $\begin{array}{c}\text { Ideology } \\
\text { Left/right }\end{array}$ & $\begin{array}{c}\text { EU } \\
\text { benefit }\end{array}$ & $\begin{array}{c}\text { EU } \\
\text { efficacy }\end{array}$ & $\begin{array}{c}\text { Leave } \\
\text { EU }\end{array}$ & $\begin{array}{l}\text { Strong } \\
\text { Leader }\end{array}$ & $\begin{array}{c}\text { More } \\
\text { Privacy }\end{array}$ & $\begin{array}{l}\text { People } \\
\text { Power }\end{array}$ & $\begin{array}{c}\text { Free } \\
\text { Media }\end{array}$ & Plutocra. \\
\hline Covidfirst & $\begin{array}{c}0.0193 \\
(0.0216)\end{array}$ & $\begin{array}{c}-0.0145 \\
(0.0220)\end{array}$ & $\begin{array}{c}-0.00768 \\
(0.0223)\end{array}$ & $\begin{array}{c}0.0371 \\
(0.0231)\end{array}$ & $\begin{array}{c}-0.0989^{* * *} \\
(0.0216)\end{array}$ & $\begin{array}{c}-0.0940^{* * * *} \\
(0.0235)\end{array}$ & $\begin{array}{c}0.0128 \\
(0.0226)\end{array}$ & $\begin{array}{c}-0.0481^{*} \\
(0.0252)\end{array}$ & $\begin{array}{c}-0.0340 \\
(0.0224)\end{array}$ & $\begin{array}{c}-0.0480^{* *} \\
(0.0236)\end{array}$ & $\begin{array}{c}-0.00234 \\
(0.0236)\end{array}$ & $\begin{array}{r}-0.00127 \\
(0.0234)\end{array}$ \\
\hline Worried & $\begin{array}{c}0.0244 \\
(0.0208)\end{array}$ & $\begin{array}{c}0.0113 \\
(0.0180)\end{array}$ & $\begin{array}{l}0.00445 \\
(0.0177)\end{array}$ & $\begin{array}{c}0.0706^{* * *} \\
(0.0239)\end{array}$ & $\begin{array}{c}0.0970^{* * *} \\
(0.0210)\end{array}$ & $\begin{array}{c}0.0891^{* * *} \\
(0.0205)\end{array}$ & $\begin{array}{c}-0.0123 \\
(0.0193)\end{array}$ & $\begin{array}{c}0.143^{* * *} \\
(0.0179)\end{array}$ & $\begin{array}{c}0.0812^{\text {*** }} \\
(0.0237)\end{array}$ & $\begin{array}{c}0.0887^{* * *} \\
(0.0219)\end{array}$ & $\begin{array}{c}-0.0478^{* *} \\
(0.0187)\end{array}$ & $\begin{array}{c}-0.0269 \\
(0.0206)\end{array}$ \\
\hline Covidfirst*worried & $\begin{array}{l}-0.0118 \\
(0.0226)\end{array}$ & $\begin{array}{c}0.0317 \\
(0.0231)\end{array}$ & $\begin{array}{c}0.0260 \\
(0.0226)\end{array}$ & $\begin{array}{c}-0.00892 \\
(0.0302)\end{array}$ & $\begin{array}{l}0.00256 \\
(0.0234)\end{array}$ & $\begin{array}{c}0.0182 \\
(0.0242)\end{array}$ & $\begin{array}{l}0.00127 \\
(0.0239)\end{array}$ & $\begin{array}{c}-0.0169 \\
(0.0243)\end{array}$ & $\begin{array}{l}-0.0124 \\
(0.0279)\end{array}$ & $\begin{array}{c}-0.0463^{*} \\
(0.0239)\end{array}$ & $\begin{array}{c}0.0172 \\
(0.0220)\end{array}$ & $\begin{array}{c}0.0373 \\
(0.0243)\end{array}$ \\
\hline $\mathrm{Ob}$ & 8,235 & 8 & & 8,2 & 8,235 & 8,235 & 8,2 & & 8,23 & 8,2 & 8,235 & 8,235 \\
\hline R-squared & 0.015 & 0.085 & 0.064 & 0.057 & 0.078 & 0.067 & 0.042 & 0.042 & 0.042 & 0.045 & 0.079 & 0.045 \\
\hline
\end{tabular}

The table presents estimates from OLS models. The outcome variables are stated in the first row. The analysis interacts COVIDFIRST with a variable indicating the respondent's level of concern with the epidemic. Controls include gender, age groups, employment status, education, immigrant status, family status and number of family members, equivalised household income (coded into five quantiles), a dummy to define the position of the Macron Speech question (see Section 3.1 for more details) and country fixed effects. All controls are omitted to enhance readability. Robust standard errors clustered at the province level are in parentheses. ${ }^{*} p<0.1 ; * * p<0.05 ; * * * p<0.01$

Table B44: Heterogeneous effects of concern with the epidemic: Identity

\begin{tabular}{|c|c|c|c|c|c|c|c|c|c|}
\hline & $\begin{array}{c}\text { Belong } \\
\text { Town }\end{array}$ & $\begin{array}{l}\text { Belong } \\
\text { Nation }\end{array}$ & $\begin{array}{c}\text { Belong } \\
\text { EU }\end{array}$ & $\begin{array}{l}\text { - Own Freedom } \\
+ \text { Public Safety }\end{array}$ & $\begin{array}{l}\text { - Own Freedom } \\
+ \text { Own Safety }\end{array}$ & $\begin{array}{l}\text { - Own Freedom } \\
+ \text { Family Safety }\end{array}$ & $\begin{array}{c}\text { Global Human } \\
\text { Rights }\end{array}$ & $\begin{array}{c}\text { Respect } \\
\text { Traditions }\end{array}$ & $\begin{array}{c}\text { Less } \\
\text { Globalization } \\
\end{array}$ \\
\hline Covidfirst & $\begin{array}{l}-0.0129 \\
(0.0232)\end{array}$ & $\begin{array}{c}0.0306 \\
(0.0217)\end{array}$ & $\begin{array}{c}-0.0715^{* * *} \\
(0.0199)\end{array}$ & $\begin{array}{l}-0.00863 \\
(0.0209)\end{array}$ & $\begin{array}{l}0.00184 \\
(0.0230)\end{array}$ & $\begin{array}{l}-0.0141 \\
(0.0230)\end{array}$ & $\begin{array}{l}0.00371 \\
(0.0230)\end{array}$ & $\begin{array}{c}0.0139 \\
(0.0241)\end{array}$ & $\begin{array}{l}0.00121 \\
(0.0220)\end{array}$ \\
\hline Worried & $\begin{array}{l}0.0412^{*} \\
(0.0212)\end{array}$ & $\begin{array}{c}0.0888^{* * * *} \\
(0.0217)\end{array}$ & $\begin{array}{c}0.104^{* * *} \\
(0.0184)\end{array}$ & $\begin{array}{c}0.202^{* * *} * \\
(0.0191)\end{array}$ & $\begin{array}{c}0.194^{* * *} \\
(0.0198)\end{array}$ & $\begin{array}{c}0.144^{* * *} \\
(0.0172)\end{array}$ & $\begin{array}{l}-0.0260 \\
(0.0191)\end{array}$ & $\begin{array}{c}0.0726^{* * *} \\
(0.0185)\end{array}$ & $\begin{array}{c}0.0899^{* * *} \\
(0.0201)\end{array}$ \\
\hline Covidfirst*worried & $\begin{array}{c}0.0271 \\
(0.0223)\end{array}$ & $\begin{array}{c}0.0147 \\
(0.0237)\end{array}$ & $\begin{array}{l}0.00452 \\
(0.0236)\end{array}$ & $\begin{array}{c}0.0185 \\
(0.0237)\end{array}$ & $\begin{array}{c}-0.000307 \\
(0.0260)\end{array}$ & $\begin{array}{c}0.0262 \\
(0.0272)\end{array}$ & $\begin{array}{c}0.0156 \\
(0.0237)\end{array}$ & $\begin{array}{l}0.00713 \\
(0.0227)\end{array}$ & $\begin{array}{l}-0.00439 \\
(0.0242)\end{array}$ \\
\hline Observations & 8,235 & 8,235 & 8,235 & 8,235 & 8,235 & 8,235 & 8,235 & 8,235 & 8,235 \\
\hline
\end{tabular}

The table presents estimates from OLS models. The outcome variables are stated in the first row. The analysis interacts COVIDFIRST with a variable indicating the respondent's level of concern with the epidemic. Controls include gender, age groups, employment status, education, immigrant status, family status and number of family members, equivalised household income (coded into five quantiles), a dummy to define the position of the Macron Speech question (see Section 3.1 for more details) and country fixed effects. All controls are omitted to enhance readability. Robust standard errors clustered at the province level are in parentheses. $* p<0.1 ; * *<<0.05 ; * * * p<0.01$ 


\section{B.5 Conflict condition: Spain vs other countries}

Table B45: Effects of the Conflict condition in Germany, Italy and the Netherlands - Trust

\begin{tabular}{|c|c|c|c|c|c|c|c|c|}
\hline & $\begin{array}{l}\text { Macron } \\
\text { Speech }\end{array}$ & $\begin{array}{c}\text { Trust } \\
\text { Politicians }\end{array}$ & $\begin{array}{l}\text { Social } \\
\text { Trust }\end{array}$ & $\begin{array}{c}\text { Trust } \\
\text { Government }\end{array}$ & $\begin{array}{l}\text { Trust } \\
\text { Police }\end{array}$ & $\begin{array}{l}\text { Trust } \\
\text { Media }\end{array}$ & $\begin{array}{c}\text { Trust } \\
\text { Science }\end{array}$ & $\begin{array}{c}\text { Trust } \\
\text { EU }\end{array}$ \\
\hline Conflict & $\begin{array}{l}-0.0179 \\
(0.0409)\end{array}$ & $\begin{array}{c}0.000863 \\
(0.0403)\end{array}$ & $\begin{array}{c}0.0418 \\
(0.0397)\end{array}$ & $\begin{array}{l}-0.0124 \\
(0.0392)\end{array}$ & $\begin{array}{l}0.00262 \\
(0.0385)\end{array}$ & $\begin{array}{l}0.00623 \\
(0.0383)\end{array}$ & $\begin{array}{c}0.109^{* * *} \\
(0.0383)\end{array}$ & $\begin{array}{c}0.0126 \\
(0.0380)\end{array}$ \\
\hline Observations & 2,782 & 2,782 & 2,782 & 2,782 & 2,782 & 2,782 & 2,782 & 2,782 \\
\hline R-squared & 0.071 & 0.171 & 0.065 & 0.110 & 0.045 & 0.143 & 0.058 & 0.028 \\
\hline
\end{tabular}

The table presents estimates from OLS models. The outcome variables are stated in the first row. The sample compares the Conflict condition to the Health group and it includes only respondents in Germany, Italy and the Netherlands. Controls include gender, age groups, employment status, education, immigrant status, family status and number of family members, equivalised household income (coded into five quantiles), a dummy to define the position of the Macron Speech question (see Section 3.1 for more details) and country fixed effects. All controls are omitted to enhance readability. Robust standard errors clustered at the province level are in parentheses. ${ }^{*} p<0.1 ; * *<<0.05 ; * * *<0.01$

Table B46: Effects of the Conflict condition in Germany, Italy and the Netherlands - Taxation

\begin{tabular}{lcccccccccc}
\hline & $\begin{array}{c}\text { Regulate } \\
\text { Markets }\end{array}$ & $\begin{array}{c}\text { +Taxes } \\
\text {-Poverty }\end{array}$ & $\begin{array}{c}\text { +Taxes } \\
\text { +Health Exp. }\end{array}$ & $\begin{array}{c}\text { +Taxes } \\
\text { +Unemp. Welf. }\end{array}$ & $\begin{array}{c}\text { +Taxes } \\
\text { +Pensions }\end{array}$ & $\begin{array}{c}\text { Too Many } \\
\text { Immigrants }\end{array}$ & $\begin{array}{c}\text { Health Exp. } \\
\text { to Natives }\end{array}$ & $\begin{array}{c}\text { General Tax } \\
\text { too High }\end{array}$ & $\begin{array}{c}\text { Self Tax } \\
\text { too High }\end{array}$ \\
\hline Conflict & & & & & & & & & & \\
& 0.0169 & -0.0368 & -0.00938 & 0.00789 & 0.0194 & 0.0270 & -0.00505 & -0.00851 & 0.0465 \\
& $(0.0383)$ & $(0.0342)$ & $(0.0413)$ & $(0.0366)$ & $(0.0388)$ & $(0.0434)$ & $(0.0413)$ & $(0.0356)$ & $(0.0349)$ \\
Observations & & & & & & & & & \\
R-squared & 0.782 & 2,782 & 2,782 & 2,782 & 2,782 & 2,782 & 2,782 & 2,782 & 2,782 \\
\hline
\end{tabular}

The table presents estimates from OLS models. The outcome variables are stated in the first row. The sample compares the Conflict condition to the Health group and it includes only respondents in Germany, Italy and the Netherlands. Controls include gender, age groups, employment status, education, immigrant status, family status and number of family members, equivalised gender, age groups, employment status, education, immigrant status, family status and number of family members, equivalised household income (coded into five quantiles), a dummy to define the position of the Macron Speech question (see Section 3.1 for more details) and country fixed effects. All controls are omitted to enhance readability. Robust standard errors clustered at the province level are in parentheses. ${ }^{*} p<0.1 ; * * p<0.05 ; * * * p<0.01$

Table B47: Effects of the Conflict condition in Germany, Italy and the Netherlands - Voting

\begin{tabular}{lcccccccccccccc}
\hline & $\begin{array}{c}\text { Incumbent } \\
\text { Voting }\end{array}$ & $\begin{array}{c}\text { Populism } \\
\text { Voting }\end{array}$ & $\begin{array}{c}\text { Euroscept. } \\
\text { Voting }\end{array}$ & $\begin{array}{c}\text { Ideology } \\
\text { Left/right }\end{array}$ & $\begin{array}{c}\text { EU } \\
\text { benefit }\end{array}$ & $\begin{array}{c}\text { EU } \\
\text { efficacy }\end{array}$ & $\begin{array}{c}\text { Leave } \\
\text { EU }\end{array}$ & $\begin{array}{c}\text { Strong } \\
\text { Leader }\end{array}$ & $\begin{array}{c}\text { More } \\
\text { Privacy }\end{array}$ & $\begin{array}{c}\text { People } \\
\text { Power }\end{array}$ & $\begin{array}{c}\text { Free } \\
\text { Media }\end{array}$ & $\begin{array}{c}\text { Plutocra. } \\
\text { Conflict }\end{array}$ \\
& -0.0512 & -0.00623 & -0.0188 & -0.0410 & -0.0163 & 0.0533 & -0.0138 & -0.0484 & 0.0314 & -0.00661 & 0.00423 & 0.0428 \\
& $(0.0413)$ & $(0.0337)$ & $(0.0349)$ & $(0.0363)$ & $(0.0355)$ & $(0.0354)$ & $(0.0427)$ & $(0.0381)$ & $(0.0419)$ & $(0.0412)$ & $(0.0361)$ & $(0.0366)$ \\
& & & & & & & & & & & & & & \\
Observations & 2,782 & 2,782 & 2,782 & 2,782 & 2,782 & 2,782 & 2,782 & 2,782 & 2,782 & 2,782 & 2,782 & 2,782 \\
R-squared & 0.024 & 0.105 & 0.083 & 0.045 & 0.069 & 0.056 & 0.036 & 0.032 & 0.038 & 0.045 & 0.073 & 0.054 \\
\hline
\end{tabular}

The table presents estimates from OLS models. The outcome variables are stated in the first row. The sample compares the Conflict condition to the Health group and it includes only respondents in Germany, Italy and the Netherlands. Controls include gender, age groups, employment status, education, immigrant status, family status and number of family members, equivalised household in more details) and count controls are omitted to enhance readability. Robust standard errors clustered at the province level are in parentheses. $* p<0.1 ; * *<0.05 ; * * * p<0.01$ 
Table B48: Effects of the Conflict condition in Germany, Italy and the Netherlands - Identity

\begin{tabular}{|c|c|c|c|c|c|c|c|c|c|}
\hline & $\begin{array}{l}\text { Belong } \\
\text { Town }\end{array}$ & $\begin{array}{l}\text { Belong } \\
\text { Nation } \\
\end{array}$ & $\begin{array}{c}\text { Belong } \\
\text { EU }\end{array}$ & $\begin{array}{l}\text { - Own Freedom } \\
+ \text { Public Safety }\end{array}$ & $\begin{array}{l}\text { - Own Freedom } \\
+ \text { Own Safety }\end{array}$ & $\begin{array}{l}\text { - Own Freedom } \\
+ \text { Family Safety }\end{array}$ & $\begin{array}{c}\text { Global Human } \\
\text { Rights } \\
\end{array}$ & $\begin{array}{c}\text { Respect } \\
\text { Traditions }\end{array}$ & $\begin{array}{c}\text { Less } \\
\text { Globalization }\end{array}$ \\
\hline Conflict & $\begin{array}{c}0.0198 \\
(0.0397)\end{array}$ & $\begin{array}{c}0.0198 \\
(0.0362)\end{array}$ & $\begin{array}{r}-0.00978 \\
(0.0432)\end{array}$ & $\begin{array}{c}-0.0397 \\
(0.0373)\end{array}$ & $\begin{array}{l}-0.0132 \\
(0.0337)\end{array}$ & $\begin{array}{l}0.00599 \\
(0.0346)\end{array}$ & $\begin{array}{c}0.0555 \\
(0.0343)\end{array}$ & $\begin{array}{l}0.00724 \\
(0.0369)\end{array}$ & $\begin{array}{c}0.0169 \\
(0.0410)\end{array}$ \\
\hline Observations & 2,782 & 2,782 & 2,782 & 2,782 & 2,782 & 2,782 & 2,782 & 2,782 & 2,782 \\
\hline R-squared & 0.027 & 0.032 & 0.036 & 0.018 & 0.025 & 0.038 & 0.037 & 0.059 & 0.062 \\
\hline
\end{tabular}

The table presents estimates from OLS models. The outcome variables are stated in the first row. The sample compares the Conflict condition to the Health group and it includes only respondents in Germany, Italy and the Netherlands. Controls include gender, age groups, employment status, education, immigrant status, family status and number of family members, equivalised household income (coded into five quantiles), a dummy to define the position of the Macron Speech question (see Section 3.1 for more details) and country fixed effects. All controls are omitted to enhance readability. Robust standard errors clustered at the province level are in parentheses. ${ }^{*} p<0.1 ; * *<0.05 ; * * *<0.01$

Table B49: Effects of the Conflict condition Spain - Trust

\begin{tabular}{lcccccccc}
\hline & $\begin{array}{c}\text { Macron } \\
\text { Speech }\end{array}$ & $\begin{array}{c}\text { Trust } \\
\text { Politicians }\end{array}$ & $\begin{array}{c}\text { Social } \\
\text { Trust }\end{array}$ & $\begin{array}{c}\text { Trust } \\
\text { Government }\end{array}$ & $\begin{array}{c}\text { Trust } \\
\text { Police }\end{array}$ & $\begin{array}{c}\text { Trust } \\
\text { Media }\end{array}$ & $\begin{array}{c}\text { Trust } \\
\text { Science }\end{array}$ & $\begin{array}{c}\text { Trust } \\
\text { EU }\end{array}$ \\
\hline \multirow{2}{*}{ Conflict } & -0.0339 & $0.139^{* * *}$ & 0.110 & $0.120^{* *}$ & $0.0947^{* *}$ & $0.122^{*}$ & $0.424^{* * *}$ & $0.137^{*}$ \\
& $(0.0488)$ & $(0.0403)$ & $(0.0780)$ & $(0.0477)$ & $(0.0388)$ & $(0.0657)$ & $(0.0785)$ & $(0.0753)$ \\
& & & & & & & & 881 \\
Observations & 881 & 881 & 881 & 881 & 881 & 881 & 881 & 881 \\
R-squared & 0.074 & 0.187 & 0.044 & 0.120 & 0.035 & 0.143 & 0.054 & 0.027 \\
\hline
\end{tabular}

The table presents estimates from OLS models. The outcome variables are stated in the first row. The sample compares the Conflict condition to the Health group and it includes only respondents in Spain. Controls include gender, age groups, employment status, education, immigrant status, family status and number of family members, equivalised household income (coded into five quantiles), a dummy to define the position of the Macron Speech question (see Section 3.1 for more details) and country fixed effects. All controls are omitted to enhance readability. Robust standard errors clustered at the province level are in parentheses. ${ }^{*} p<0.1 ; * * p<0.05 ; * * * \quad p<0.01$

Table B50: Effects of the Conflict condition Spain - Taxation

\begin{tabular}{|c|c|c|c|c|c|c|c|c|c|}
\hline & $\begin{array}{c}\text { Regulate } \\
\text { Markets }\end{array}$ & $\begin{array}{l}\text { +Taxes } \\
\text {-Poverty }\end{array}$ & $\begin{array}{c}\text { + Taxes } \\
+ \text { Health Exp. }\end{array}$ & $\begin{array}{c}\text { + Taxes } \\
\text { +Unemp. Welf. }\end{array}$ & $\begin{array}{l}\text { + Taxes } \\
+ \text { Pensions }\end{array}$ & $\begin{array}{c}\text { Too Many } \\
\text { Immigrants }\end{array}$ & $\begin{array}{c}\text { Health Exp. } \\
\text { to Natives }\end{array}$ & $\begin{array}{c}\text { General Tax } \\
\text { too High }\end{array}$ & $\begin{array}{l}\text { Self Tax } \\
\text { too High }\end{array}$ \\
\hline Conflict & $\begin{array}{c}0.0127 \\
(0.0364)\end{array}$ & $\begin{array}{c}0.0356 \\
(0.0645)\end{array}$ & $\begin{array}{c}0.0530 \\
(0.0591)\end{array}$ & $\begin{array}{c}0.0331 \\
(0.0685)\end{array}$ & $\begin{array}{c}0.0355 \\
(0.0504)\end{array}$ & $\begin{array}{l}-0.0398 \\
(0.0402)\end{array}$ & $\begin{array}{l}0.00764 \\
(0.0542)\end{array}$ & $\begin{array}{c}0.0689 \\
(0.0486)\end{array}$ & $\begin{array}{c}0.0645 \\
(0.0565)\end{array}$ \\
\hline Observations & 881 & 881 & 881 & 881 & 881 & 881 & 881 & 881 & 881 \\
\hline R-squared & 0.072 & 0.015 & 0.067 & 0.066 & 0.053 & 0.044 & 0.028 & 0.137 & 0.131 \\
\hline
\end{tabular}

The table presents estimates from OLS models. The outcome variables are stated in the first row. The sample compares the Conflict condition to the Health group and it includes only respondents in Spain. Controls include gender, age groups, employment status, education, immigrant status, family status and number of family members, equivalised household income (coded into five quantiles), a dummy to define the position of the Macron Speech question (see Section 3.1 for more details) and country fixed effects. All controls are omitted to enhance readability. Robust standard errors clustered at the province level are in parentheses. ${ }^{*} p<0.1$; ** $p<0.05$; *** $p<0.01$ 
Table B51: Effects of the Conflict condition Spain - Voting

\begin{tabular}{|c|c|c|c|c|c|c|c|c|c|c|c|c|}
\hline & $\begin{array}{c}\text { Incumbent } \\
\text { Voting }\end{array}$ & $\begin{array}{c}\text { Populism } \\
\text { Voting } \\
\end{array}$ & $\begin{array}{c}\text { Euroscept. } \\
\text { Voting }\end{array}$ & $\begin{array}{c}\text { Ideology } \\
\text { Left/right }\end{array}$ & $\begin{array}{c}\text { EU } \\
\text { benefit }\end{array}$ & $\begin{array}{c}\text { EU } \\
\text { efficacy }\end{array}$ & $\begin{array}{c}\text { Leave } \\
\text { EU }\end{array}$ & $\begin{array}{l}\text { Strong } \\
\text { Leader }\end{array}$ & $\begin{array}{c}\text { More } \\
\text { Privacy }\end{array}$ & $\begin{array}{l}\text { People } \\
\text { Power }\end{array}$ & $\begin{array}{c}\text { Free } \\
\text { Media }\end{array}$ & Plutocra. \\
\hline Conflict & $\begin{array}{l}-0.0477 \\
(0.0562)\end{array}$ & $\begin{array}{l}-0.0518 \\
(0.0561)\end{array}$ & $\begin{array}{l}-0.0460 \\
(0.0602)\end{array}$ & $\begin{array}{l}-0.0513 \\
(0.0702)\end{array}$ & $\begin{array}{l}-0.00304 \\
(0.0873)\end{array}$ & $\begin{array}{l}0.102^{* *} \\
(0.0491)\end{array}$ & $\begin{array}{c}-0.103^{* *} \\
(0.0449)\end{array}$ & $\begin{array}{l}-0.00738 \\
(0.0547)\end{array}$ & $\begin{array}{c}0.137^{* * *} \\
(0.0408)\end{array}$ & $\begin{array}{l}-0.0214 \\
(0.0814)\end{array}$ & $\begin{array}{c}0.0199 \\
(0.0714)\end{array}$ & $\begin{array}{c}0.0340 \\
(0.0743)\end{array}$ \\
\hline $\begin{array}{l}\text { Observations } \\
\text { R-squared }\end{array}$ & $\begin{array}{c}881 \\
0.014\end{array}$ & $\begin{array}{c}881 \\
0.084\end{array}$ & $\begin{array}{c}881 \\
0.069\end{array}$ & $\begin{array}{c}881 \\
0.070\end{array}$ & $\begin{array}{c}881 \\
0.084\end{array}$ & $\begin{array}{c}881 \\
0.083\end{array}$ & $\begin{array}{c}881 \\
0.060\end{array}$ & $\begin{array}{c}881 \\
0.046\end{array}$ & $\begin{array}{c}881 \\
0.031\end{array}$ & $\begin{array}{c}881 \\
0.033\end{array}$ & $\begin{array}{c}881 \\
0.080\end{array}$ & $\begin{array}{c}881 \\
0.052\end{array}$ \\
\hline
\end{tabular}

The table presents estimates from OLS models. The outcome variables are stated in the first row. The sample compares the Conflict condition to the Health group and it includes only respondents in Spain. Controls include gender, age groups, employment status, education, immigrant status, family status and number of family members, equivalised household income (coded into five quantiles), a dummy to define the position of the Macron Speech question (see Section 3.1 for more details) and country fixed effects. All controls are omitted to enhance readability. Robust standard errors clustered at the province level are in parentheses. $* p<0.1 ; * * \quad p<0.05 ; * * * p<0.01$

Table B52: Effects of the Conflict condition Spain - Identity

\begin{tabular}{lccccccccc}
\hline & $\begin{array}{c}\text { Belong } \\
\text { Town }\end{array}$ & $\begin{array}{c}\text { Belong } \\
\text { Nation }\end{array}$ & $\begin{array}{c}\text { Belong } \\
\text { EU }\end{array}$ & $\begin{array}{c}\text { - Own Freedom } \\
\text { + Public Safety }\end{array}$ & $\begin{array}{c}\text { - Own Freedom } \\
\text { + Own Safety }\end{array}$ & $\begin{array}{c}\text { - Own Freedom } \\
\text { + Family Safety }\end{array}$ & $\begin{array}{c}\text { Global Human } \\
\text { Rights }\end{array}$ & $\begin{array}{c}\text { Respect } \\
\text { Traditions }\end{array}$ & $\begin{array}{c}\text { Less } \\
\text { Globalization }\end{array}$ \\
\hline Conflict & 0.116 & $0.103^{*}$ & 0.0965 & 0.0772 & 0.0367 & 0.0429 & -0.0804 & $0.157^{* * *}$ & -0.0603 \\
& $(0.0727)$ & $(0.0557)$ & $(0.0607)$ & $(0.0644)$ & $(0.0629)$ & $(0.0562)$ & $(0.0552)$ & $(0.0560)$ & $(0.0558)$ \\
& & & & & & & & & \\
Observations & 881 & 881 & 881 & 881 & 881 & 881 & 881 & 881 & 881 \\
R-squared & 0.043 & 0.027 & 0.039 & 0.020 & 0.029 & 0.035 & 0.040 & 0.067 & 0.050 \\
\hline
\end{tabular}

The table presents estimates from OLS models. The outcome variables are stated in the first row. The sample compares the Conflict condition to the Health group and it includes only respondents in Spain. Controls include gender, age groups, employment status, education, immigrant status, family status and number of family members, equivalised household income (coded into five quantiles), a dummy to define the position of the Macron Speech question (see Section 3.1 for more details) and country fixed effects. All controls are omitted to enhance readability. Robust standard errors clustered at the province level are in parentheses. ${ }^{*} p<0.1 ; * * p<0.05$; *** $p<0.01$ 


\section{Robustness analyses}

\section{C.1 Demand effects: the text agreement question}

Figure $\mathrm{C} 1$ illustrates the coefficients associated to a dummy variable indicating whether the respondents were asked whether they wished to read the text about the European Union integration before or after they had answered our target outcome questions. The coefficients are statistically indistinguishable from zero in almost all cases, and they are small and unsystematic wherever they are significantly different at conventional levels. We interpret this finding as evidence that demand effects, intended as in respondents trying to provide answers in alignment with the perceived objectives of the experimenters, originating from the text agreement questions are small in our survey. As the question is explicitly asking the respondents to incur into effort and time costs to engage in an action that is explicitly pro-EU, we take the demand effects originating from this question as upper bounds to any demand effects potentially induced by the questionnaire itself. 
Figure C1: Effect of the position of the text agreement question
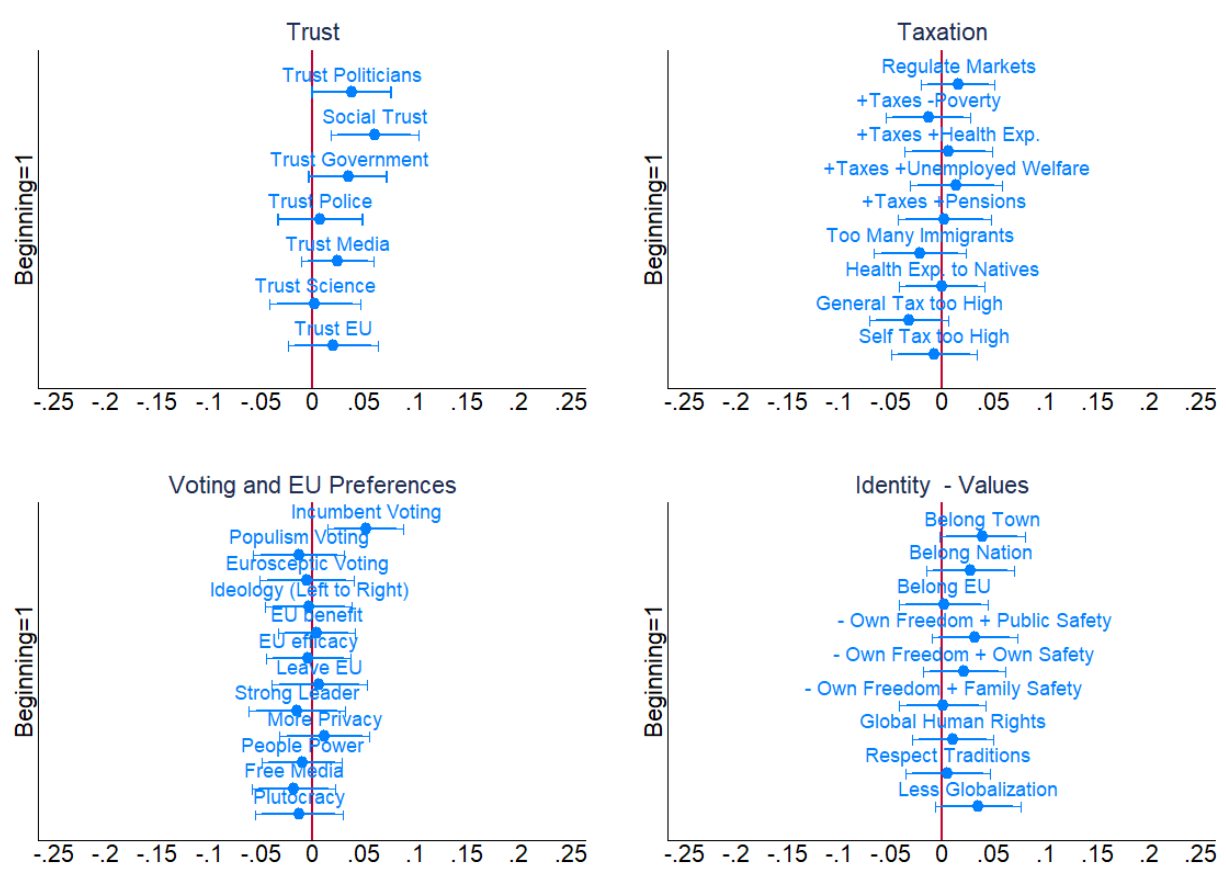

The figure displays the impact of the text agreement question being positioned at the very beginning of the socio-political attitudes block on the answers provided later in comparison to the answers provided in the socio-political attitudes block when the text agreement question is placed at the end of the block.

\section{C.2 Placebo tests}

Figures C2 and C3 present the impact on our target outcomes of participating in the Economic or Conflict conditions (see Section 3) rather than in the Health condition after having already answered the socio-political attitudes block of question. As participation occurs after the outcomes block, we expect no systematic impact of these conditions on our outcome variables. We observe that almost all of our effects are not significant at conventional levels, that they are small, and that they are not aligned with the impacts observed in our main analysis. 
Figure C2: Placebo test of the Economic condition against the Health condition in the Baseline group
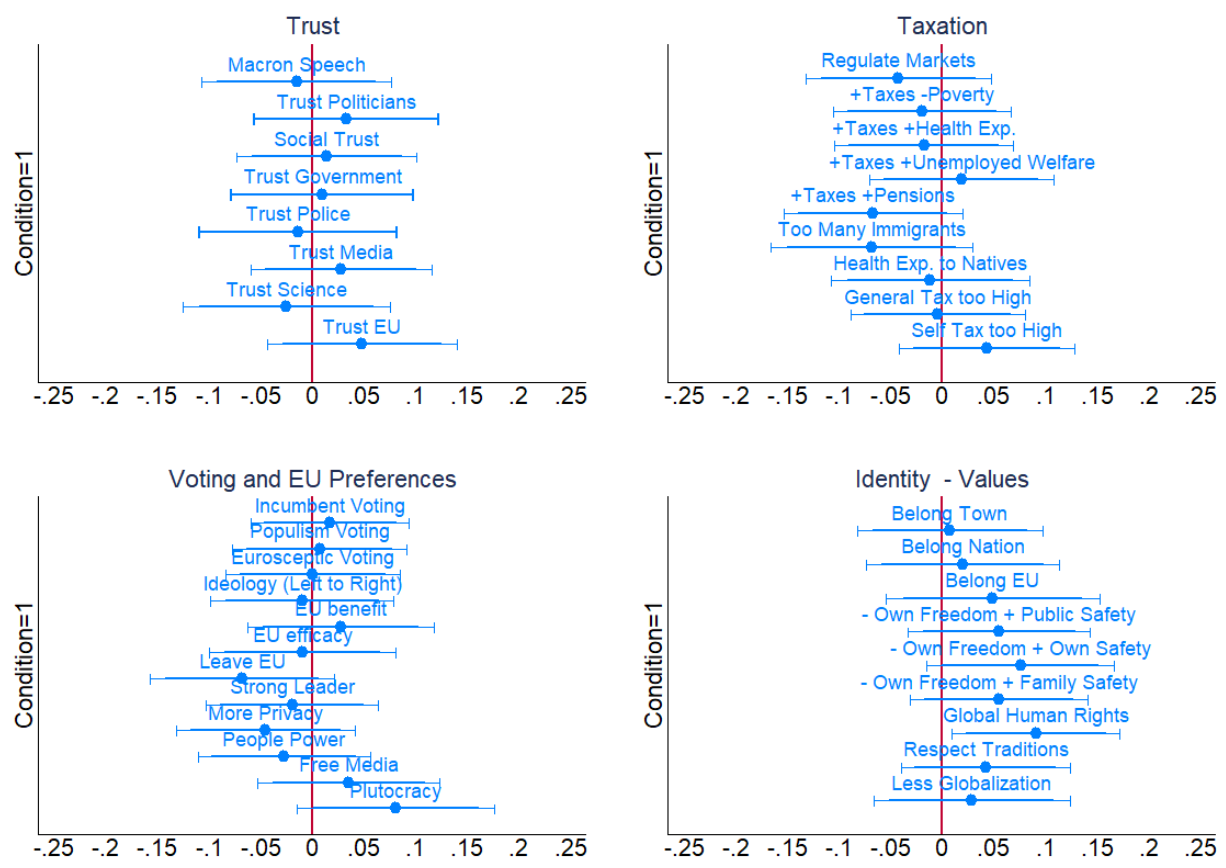

The figure displays the impact of participating in the Economic condition against participating in the Health condition in respondents who received the socio-political attitudes block of questions first and the COVID-19 block later. As the conditioning questions are asked later, they are expected not to impact the outcome responses. 
Figure C3: Placebo test of the Conflict condition against the Health condition in the Baseline group
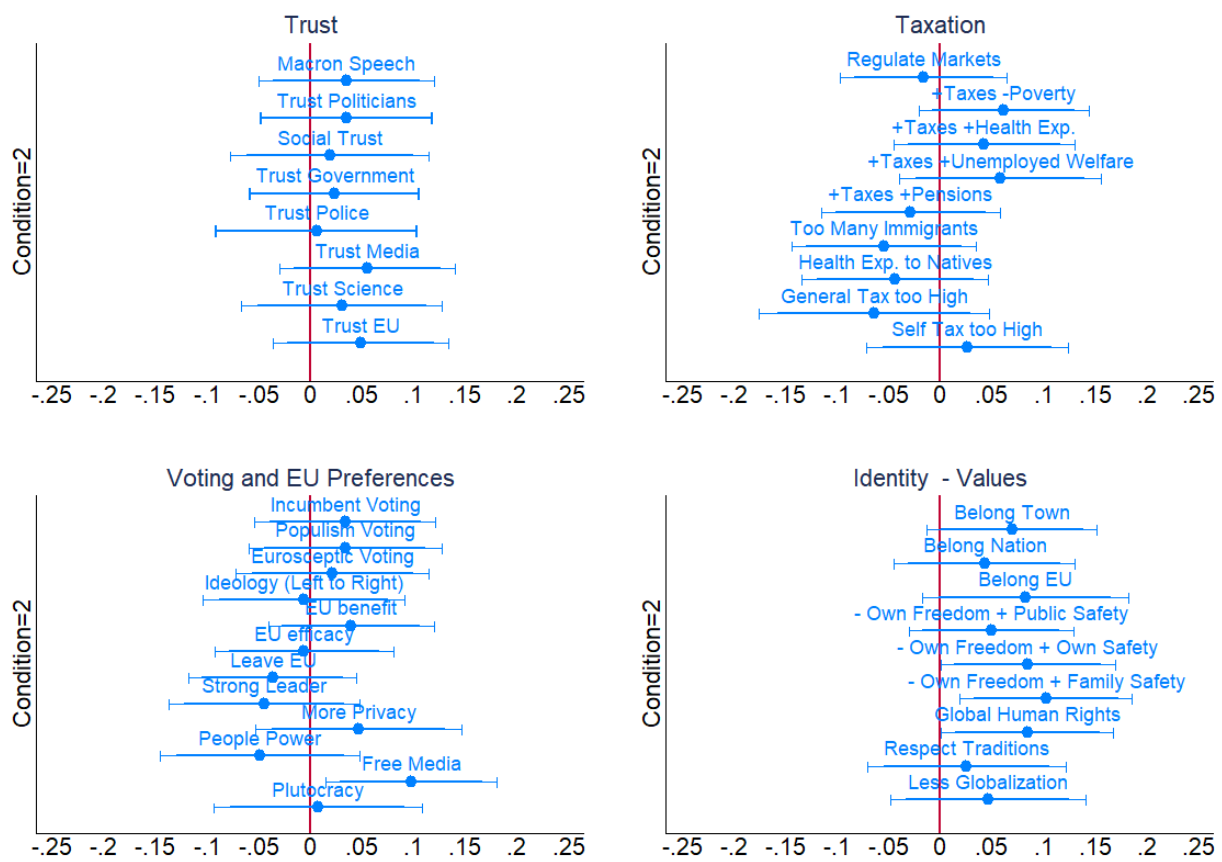

The figure displays the impact of participating in the Conflict condition against participating in the Health condition in respondents who received the socio-political attitudes block of questions first and the COVID-19 block later. As the conditioning questions are asked later, they are expected not to impact the outcome responses. 


\section{Factor analyses for the heterogeneity analysis}

In Section 5.4 we study whether the effects of our conditions vary with individuals' experience with the COVID-19 epidemic. We specifically focus on the questions included in the health subcondition as these were asked to all respondents in the study.

We group these statements into three groups: i) having contracted the virus or having COVID-19 cases in one's close entourage: whether the respondents, someone in their family or acquaintances, has contracted the virus; ii) the degree to which the individual complies with the lock-down laws, including whether the respondent perceived social distancing rules as being too strict, kept social distancing and wore a mask; and iii) the degree to which the respondents are concerned with the epidemic, elicited as whether they tried to get or got tested for COVID-19 and as their self-reported level of

concern about their health. We run a factor analysis on all questions in each group. In all three cases the factor analysis reveals the presence of a single factor upon which all elements load strongly (i.e. all factor loadings exceed 0.61). 
Group i) Included variables: Contracted the virus; COVID-19 cases in the family; COVID-19 cases among friends and acquaintances.

\begin{tabular}{lccccc}
\hline Factor & Eigenvalue & Explained variance & \multicolumn{2}{c}{ Rotated factor loadings } \\
& & & Contracted & Cases in family & Cases among friends \\
1 (retained) & 1.43 & 0.48 & 0.67 & 0.76 & 0.63 \\
2 & 0.87 & 0.29 & & & \\
3 & 0.70 & 0.23 & & & \\
\hline
\end{tabular}

Group ii) Included variables: social distancing rules are too rigid; respected social distancing rules; wore a face mask.

\begin{tabular}{lccccc}
\hline Factor & Eigenvalue & Explained variance & \multicolumn{2}{c}{ Rotated factor loadings } \\
& & & Rigidity & Respected distancing & Wore a mask \\
1 (retained) & 1.42 & 0.47 & -0.65 & 0.79 & 0.61 \\
2 & 0.91 & 0.30 & & & \\
3 & 0.67 & 0.23 & & & \\
\hline
\end{tabular}

Group iii) Included variables: got tested for COVID-19; health related concern level.

\begin{tabular}{lcccc}
\hline Factor & Eigenvalue & Explained variance & \multicolumn{2}{c}{ Rotated factor loadings } \\
Got tested & Concern \\
1 (retained) & 1.14 & 0.57 & 0.75 & 0.75 \\
2 & 0.86 & 0.43 & & \\
\hline
\end{tabular}

\section{E The text agreement question: behavioural analyses}

The analyses here presented follow the analytical framework outlined in Section 4.

Table E1 reports the summary statistics of the recorded time spent on the text screen by the respondents who chose to read the text. The Table disaggregates by Baseline and COVIDFIRST and by the subconditions of the latter. In order to obtain a more realistic picture, we trim the data by excluding from the analysis the upper tail of the distribution of time spent reading text: the top $1 \%$. These are respondents who spent half an hour or more on the text screen. 
Table E1: Summary statistcs of time in seconds spent by the respondents on the text screen

\begin{tabular}{lcc}
\hline Condition & Mean & St. dev. \\
& & \\
Baseline & 204.56 & 248.75 \\
COVIDFIRST & 218.03 & 258.04 \\
& & \\
Health & 217.57 & 264.42 \\
Economic & 213.72 & 242.40 \\
Conflict & 222.72 & 266.34 \\
\hline
\end{tabular}

The respondents spent on average 213 seconds (slightly short of 4 minutes) on the text screen, with little variation across conditions.

Table E2 uses OLS analyses to look for differences in the amount of time spent reading the text across conditions. Differences in time spent on the text are mostly not significant at conventional levels, and where significant they are small in magnitude. The largest recorded difference is that observed between COVIDFIRST and the Baseline: Respondents in the former condition spent on average 13 seconds more on the text screen than respondents in the Baseline condition. 
Table E2: Effects of the treatment conditions on time spent reading the text

\begin{tabular}{|c|c|c|c|c|}
\hline \multirow[b]{2}{*}{ Model } & $(1)$ & $(2)$ & $(3)$ & $(4)$ \\
\hline & \multicolumn{4}{|c|}{ Time in seconds spent on the text screer } \\
\hline $\begin{array}{l}\text { (1): COVIDFIRST } \\
\text { vs Baseline }\end{array}$ & $\begin{array}{l}13.03^{* *} \\
(5.862)\end{array}$ & & & \\
\hline $\begin{array}{l}(2) \text { : Health } \\
\text { vs Baseline }\end{array}$ & & $\begin{array}{c}10.86 \\
(8.155)\end{array}$ & & \\
\hline $\begin{array}{l}(3) \text { : Economic } \\
\text { vs Health }\end{array}$ & & & $\begin{array}{l}-3.010 \\
(10.23)\end{array}$ & \\
\hline $\begin{array}{l}(4) \text { : Conflict } \\
\text { vs Health }\end{array}$ & & & & $\begin{array}{c}7.160 \\
(10.74)\end{array}$ \\
\hline $\begin{array}{l}\text { Observations } \\
\text { R-squared }\end{array}$ & $\begin{array}{l}5,799 \\
0.024\end{array}$ & $\begin{array}{l}3,313 \\
0.025\end{array}$ & $\begin{array}{l}2,513 \\
0.022\end{array}$ & $\begin{array}{l}2,535 \\
0.031\end{array}$ \\
\hline
\end{tabular}

The table presents estimates from OLS models. The outcome variable is the time in seconds spent reading the text about European integration. The regressions compare time spent on the text between COVIDFIRST and Baseline, between Health and Baseline, between Economic and Health and between Conflict and Health. We exclude respondents who are recorded to spend more than 1849 seconds (30.8 minutes) on the text screen. Controls include gender, age groups, employment status, education, immigrant status, family status and number of family members, equivalised household income (coded into five quantiles), a dummy to define the position of the Macron Speech question (see Section 3.1 for more details) and country fixed effects. All controls are omitted to enhance readability. Robust standard errors clustered at the province level are in parentheses. ${ }^{*} p<0.1 ; * * p<0.05 ;{ }^{* * *} p<0.01$

Figures E1 to ?? compare the distributions of the text ratings in, respectively, the COVIDFIRST and Baseline, the Health and Baseline, the Economic and Health and in the Conflict and Health conditions. 
Figure E1: Distribution of text ratings in the COVIDFIRST and Baseline conditions
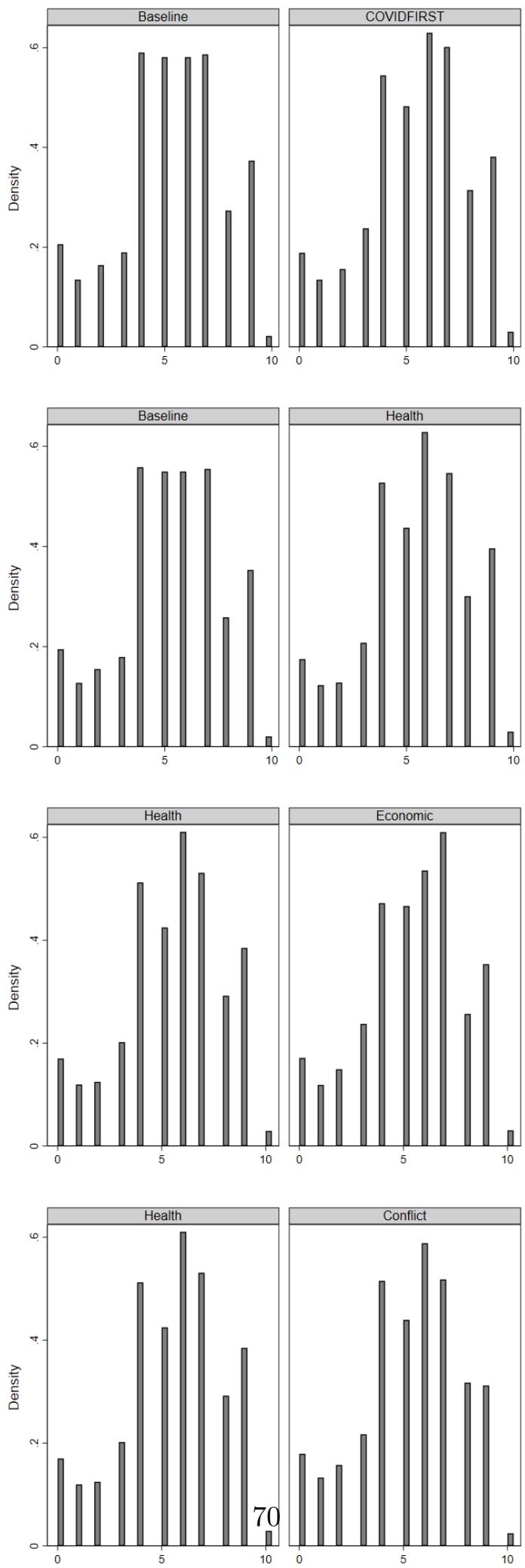

The figure shows the distribution of the ratings assigned to the text about European integration assigned by the respondents who agreed to read the text across the four study conditions: i) Covidfirst Vs baseline; ii) Health Vs baseline; Economic Vs Health; Conflict Vs Health. We exclude respondents who are recorded to spend more than 1849 seconds (30.8 minutes) on the text screen. 
As evident from the Figures, the distributions are extremely similar in all cases. Two-sided Kolmogorov-Smirnov tests cannot reject the null hypothesis of equality of the populations in three out of four cases. P-values are reported in Table E3.

Table E3: Kolmogorov-Smirnov tests: equality of the distribution of text ratings

\begin{tabular}{ccccc}
\hline & COVIDFIRST vs & Health vs & Economic vs & Conflict vs \\
& Baseline & Baseline & Health & Health \\
Two-sided p-values & 0.118 & 0.060 & 0.973 & 0.794 \\
\hline
\end{tabular}

The table reports the two-sided Kolmogorov-Smirnov tests of distribution equality of the ratings assigned to the Euroepean integration text by the respondents who chose to read it. We exclude respondents who are recorded to spend more than 1849 seconds (30.8 minutes) on the text screen.

Finally, we investigate whether a relationship exists between the rating assigned to the text and the time spent reading it among those who chose to do so. Table E4 reports the results of an OLS regression. Not surprisingly those who assigned a greater rating also spent a significantly larger amount of time reading the text. Notice however that though precisely estimated, the coefficient is small: an additional 30 seconds increases the score by 0.02 points.

Table E4: OLS regression of the rating assigned to the text on the time spent on the text screen

Rating assigned

Time in seconds spent

$0.000871^{* * *}$ on the text screen

\begin{tabular}{lr} 
Observations & 5,799 \\
R-squared & 0.025 \\
\hline
\end{tabular}

The table presents estimates from OLS models. The outcome variable is the rating assigned to the text about European integration. We exclude respondents who are recorded to spend more than 1849 seconds (30.8 minutes) on the text screen. Controls include gender, age groups, employment status, education, immigrant status, family status and number of family members, equivalised household income (coded into five quantiles), a dummy to define the position of the Macron Speech question (see Section 3.1 for more details) and country fixed effects. All controls are omitted to enhance readability. Robust standard errors clustered at the province level are in parentheses. * $p<0.1 ; * * p<0.05 ; * * * p<0.01$ 
F Questionnaire 


\section{Covid-19 and Europeans' Attitudes towards EU intervention}

\section{Investigators:}

- Gianmarco Daniele, Università Bocconi, Università di Milano;

- Andrea Martinangeli, Max Planck Institute for Tax Law and Public Finance;

- Francesco Passarelli, Università Bocconi, Università di Torino;

- Willem Sas, University of Stirling, KU Leuven;

- Lisa Windsteiger, Max Planck Institute for Tax Law and Public Finance;

Survey location: Italy, Spain, Germany, Netherlands

Target sample: random sample of the adult population representative over age, gender and income (2000 respondents per country) 


\section{Survey questionnaire draft}

We are non-partisan researchers from an independent research institute.

We would like to know your personal views on matters of public interest.

It is very important that you provide your true opinion, and that you read all the questions very carefully before answering. If you do not know the answer to some question, please provide us with a careful guess. However, please be sure to spend enough time reading and understanding the question. Responding without adequate effort or skipping many questions may result in your responses being flagged for low quality and you may not receive your payment.

It is very important that you complete the entire survey, once you've started. It should take approximately 20 minutes to complete.

Note: Your participation in this study is purely voluntary. No identifying information will be recorded by the researchers. Results may include summary data, but you will never be identified. The data will be stored on our servers and will be kept confidential. The anonymous data collected may be made available to other researchers for replication purposes.

1. Yes, I would like to participate in this survey. / No, I would not like to participate in this survey.

2. What is your gender? (M/F)

3. Please indicate your age:

4. What is your area of residence? [Country dependent] North, NorthE, NorthW, Centre, South, Islands

5. What is your marital status?

a. Single (Never Married/Widowed/Separated/Divorced)

b. Married /Civil partnership/Cohabiting

6. Please indicate how many people live in your household (including yourself): Adults... Children...

7. What is the combined monthly income of your household, after taxes?

[Please include all your household income sources: salaries, scholarships, pension and Social Security benefits, dividends from shares, income from rental properties, child support and alimony etc. We are not interested in the type of income source, only in the total monthly income earned by all the members of your household together.]
1. $<2000$
2. $2000-4000$
3. $4000-6000$
4. $6000-8000$
5. $8000-10000$
6. $>10000$

8. [Country] is divided into regions [Italy]/provinces [Netherlands]/länder [Germany]/regions [Spain]. How many regions have you visited at least once in the past 12 months besides your own? This question's only purpose is that of allowing us to check the quality of the answers we received so far. To continue with the questionnaire, please enter 30 to proceed with the questionnaire. 


\section{++++BLOCK 1: TREATMENT QUESTIONS}

\section{QUESTIONS TREATMENT GROUP T1: Health/Crisis experience}

10. On a scale from 1 to 10 , to what extent do the following statements describe your behavior during the COVID-19 confinement period? ( $1=$ not at all; $10=$ a lot)
a. I worked from home
b. I kept more distance with people than usual
c. I stocked up on food
d. I bought face masks
e. I cleaned my house/apartment with disinfectant products
f. I tried to get or got tested for COVID-19
g. I have donated or volunteered to help combat COVID-19

11. Do you have relatives who are risk patients of COVID-19?
a. Yes
b. No
c. Don't know

12. Please indicate whether the following applies to you:
a. I contracted the virus (YES/NO/DON'T KNOW)
b. Someone in my family or close to me has contracted the virus (YES/NO/DON'T KNOW)
c. At least one of my friends/acquaintances has contracted the virus (YES/NO/DON'T KNOW)

13. On a scale from 1 to 10 , do the following statements about the COVID-19 confinement apply to you personally? (1= not at all; $10=$ a lot)
a. Living together with my family/household was difficult
b. I was concerned about my health
c. Not seeing my friends or family was difficult
d. I thought the social isolation rules were too strict

14. On a scale from 1 to 10 , and when you think about the COVID-19 crisis, how much of your time did you feel:
a. Relaxed (1= never, $10=$ always)
b. Angry (1= never, $10=$ always $)$
c. Nervous (1=never, $10=$ always $)$
d. Active (1= never, $10=$ always)
e. Anxious ( $1=$ never, $10=$ always)

\section{QUESTION ONLY FOR T1}

15. Which of the following appliances do you have in your house/flat?
a. PC/laptop (Yes/No)
b. TV (Yes/No)
c. Microwave (Yes/No)
d. Internet (Yes/No)
e. Airconditioning (Yes/No)
f. Refrigerator (Yes/No)

16. On a scale from 1 to 10 , and when you think about COVID-19 crisis, do you think that

a. there were problems with food supplies in [Country] ( $1=$ not at all; $10=$ a lot $)$ 
b. There will be negative financial consequences for yourself and your family in the future ( $1=$ not at all; $10=$ a lot)

c. There will be negative financial consequences for the town in which you live in the future ( $1=$ not at all; $10=$ a lot)

17. Is the COVID-19 crisis affecting your job?
a. Yes, mostly positively
b. Yes, mostly negatively
c. Not significantly
d. I don't have a job

18. Is the COVID-19 crisis affecting the job of people close to you?
a. Yes, mostly positively
b. Yes, mostly negatively
c. Not significantly

19. If you would lose your job because of the crisis, how quickly do you think you would find a new job once the economy picks up?
a. In a few weeks
b. In a few months
c. After a year

\section{QUESTIONS TREATMENT GROUP T3: T1 + National Unity/Warspeak}

20. On a scale from 1 to 10 , do you agree with the following statements? ( $1=$ not at all; $10=$ a lot $)$
a. The COVID-19 epidemic can be considered a war in which the enemy is COVID-19
b. We can defeat COVID-19 only if everyone self-sacrifices, e.g. by strictly respecting self-isolation at home
c. Healthcare personnel are the frontline soldiers, and each of us is fighting at the home-front by self- isolating and respecting the rules
d. People breaking the rules can be considered traitors and should be punished
e. Unity is the main strategy to defeat the COVID-19 crisis
f. Vaccine research is the best weapon we have, to defend us against the virus

\section{++++BLOCK 2: OUTCOME VARIABLE QUESTIONS}

\section{VOTING}

21. Imagine the national elections were coming up next [Sunday]. Which party would you vote for? [insert parties per country - this version: Italy]
a. Lega
b. Partito democratico
c. M5S
d. Forza Italia
e. Fratelli d'italia
f. Italia viva
g. Altro. Specificare:
h. Non voterei

$\underline{\text { TRUST }}$

22. On a scale from 1 to 10 , do you think one can never be careful enough in dealing with people (1), or would you say that most people can be trusted (10)? 


\section{NATIONAL SUPPORT}

23. On a scale from 0 to 10 , how much do you trust each of the following: ( $1=$ not at all; $10=$ complete trust)
a. Your national politicians
b. Your national government
c. The police
d. Your public broadcaster
e. Your national scientists/experts

\section{ATTACHMENT}

24. People may feel different degrees of attachment to their town or village, to their country or to Europe. On a scale from 1 to 10 , how attached do you feel to
a. [Country] ( $1=$ not at all, $10=$ a lot)
b. Your town/village $(1=$ not at all, $10=$ a lot $)$
c. Europe $(1=$ not at all, $10=$ a lot $)$

\section{$\underline{\text { EU SUPPORT }}$}

25. On a scale from 1 to 10 , how much do you trust the European Union ( $1=$ not at all, $10=$ a lot).

26. On a scale from 1 to 10 , would you say that [Country] has benefited from being a member of the European Union? $(1=$ not at all, $10=$ a lot $)$

27. If there was a referendum next Sunday with the following question: "Should [Country] remain a member of the European Union or leave the European Union", how would you vote?
a. Remain in the European Union
b. Leave the European Union
c. I don't know

28. On a scale from 1 to 10 , do you think the $E U$ is better placed to solve problems than national or regional governments are? ( $1=$ not at all; $10=$ best placed $)$

\section{IMMIGRATION}

29. On a scale from 1 to 10 , do you think current immigration in your country is too low (1) or too high (10)?

30. On a scale from 1 to 10 , how much do you think the public healthcare system in your country should prioritise [nationality] over immigrants $(1=$ not at all, $10=\mathrm{alot})$

\section{GOVERNMENT}

31. People have different views on what the responsibilities of the government should or should not be. On a scale from 1 to 10 , do you think the government should
a. raise taxes to subsidise the poor $(1=$ not at all; $10=\mathrm{alot})$
b. regulate markets $(1=$ not at all; $10=$ a lot $)$
c. raise taxes to ensure adequate unemployment insurance ( $1=$ not at all; $10=\mathrm{a}$ lot $)$
d. raise taxes to ensure adequate health care $(1=$ not at all; $10=a$ lot $)$
e. raise taxes to ensure a reasonable standard of living for the old ( $1=$ not at all; $10=a$ lot) 
32. On a scale from 1 to 10 , would you say that

a. the overall fiscal burden in your country is too low (1) or too high (10)?

b. your fiscal burden is too low (1) or too high (10)

\section{LIBERALISM vS POPULISM}

33. On a scale from 1 to 10 , do you agree with the following statements? ( $1=$ fully disagree; $10=$ fully agree)

a. Privacy rights should always be upheld/protected, even if they hinder efforts to combat crime.

b. The people, and not politicians, should make our most important policy decisions.

c. Politicians should have no influence over the content of public broadcasters.

d. Having a strong leader is good for [Country] even if this leader breaks the rules to obtain results.

e. A handful of powerful individuals influences political decisions even in democracies.

34. How much of your personal freedom would you be willing to give up to

a. protect your own safety? $(1=$ none; $10=$ a lot $)$

b. protect the safety of your family? $(1=$ none; $10=$ a lot $)$

c. protect public safety? $(1=$ none; $10=$ a lot $)$

\section{UNIVERSAL VS COMMUNAL}

35. On a scale from 1 to 10 , do you agree that

a. everyone should be treated equally as global citizens, with fundamental rights ( $1=$ not at all; $10=$ fully agree)

b. everyone should be loyal to the community they are part of, and respect its traditions ( $1=$ not at all; $10=$ fully agree)

\section{GLOBALISATION}

36. People have different views about market globalization. On a scale from 1 to 10 , do you favour completely globalised markets (1), complete national self-sufficiency (10).

TEXT QUESTION HERE (see end of document for details; randomly placed here or at the beginning of block 2)

\section{EU SUPPORT: COVID}

37. On a scale from 1 to 10 , do you think the European Union is managing the COVID-19 epidemic well? ( $1=$ not at all, $10=$ absolutely)

38. On a scale from 1 to 10 , do you think your national government is managing the COVID-19 epidemic well? (1= not at all, 10= absolutely)

39. Which of the following should mostly fund the economic consequences of the COVID-19 crisis?
a. Your national government
b. The European Union
c. Your regional government

40. On a scale from 1 to 10 , do you think there should be solidarity between EU member states to fund the COVID-19 costs? ( $1=$ there should not be; $10=$ there should be) 
41. Which media do you most frequently get information on world happenings from? (If you don't find your preferred outlet, please indicate the one that most closely represents it)
a. TV News
b. Social media (social networks, blogs)
c. Radio/podcasts
d. Online newspaper/newspaper app
e. Print newspaper
f. I don't follow the news

42. What is the highest level of education you have completed?
a. Primary school
b. Junior high school (middle school)
c. Professional education
d. Higher education (science/humanities)
e. University degree
f. Doctoral degree

43. What is your current employment status?
a. Employed full-time
b. Employed part-time
c. Self-employed/small business owner
d. Unemployed and looking for a job
e. Not working and not looking for a job/Long-term sick or disabled
f. Full-time parent, homemaker
g. Retired
h. Student/Pupil

44. Were you born in [Country]?

45. Were both of your parents born in [Country]??

46. What is your province of residence?

47. Where do you see yourself on the political spectrum, where 1 represents the left and 10 represents the right?

48. Did you vote in the last election?

\section{TEXT QUESTION:}

For educational purposes, we are considering to inform students about the importance of the European Union using real texts.

We selected a speech given in front of the European Parliament, which promotes European integration. It would help us if you could take 5 minutes of your time to read this speech and give us your opinion. Please notice that whether you agree to read the text or not will not affect your payment.

Yes, I want to read the text.

No, I don't want to read the text.

Next page: Thank you very much for your help, you will get to read the speech and give your opinion at the end of this survey. 


\section{At the end of the survey (if they clicked yes):}

Thank you for agreeing to review the speech on EU integration which we plan to use for educational purposes. You can find the speech below. You will be able to provide us with your opinion on the next page.

Speech is displayed.

Question after speech:

On a scale from 1 to 10, do you think this text, a speech held by Emmanuel Macron in 2018, can be used to inform students of the advantages and importance of the European Union? (1=No, 10=Yes) 